\title{
CONTRIBUiÇÃo da Agricultura AO CRESCIMENTO ECONÔMICO: O EXCEDENTE FINANCEIRO DE 1980 A 1998
}

\author{
ALEXANDRE FLORINDO ALVES \\ Engenheiro Agrônomo
}

Orientador: Prof. Dr. PAULO FERNANDO CIDADE DE ARAÚJO

Tese apresentada à Escola Superior de Agricultura "Luiz de Queiroz", Universidade de São Paulo, para obtenção do título de Doutor em Ciências, Área de Concentração: Economia Aplicada.

PIRACICABA

Estado de São Paulo - Brasil

Fevereiro - 2000 


\title{
Dados Internacionais de Catalogação na Publicação (CIP) DIVISĀO DE BIBLIOTECA E DOCUMENTAÇĀO - Campus "Luiz de Queiroz"/USP
}

\author{
Alves, Alexandre Florindo \\ Contribuição da agricultura ao crescimento econômico: o excedente financeiro de \\ 1980 a 1998 / Alexandre Florindo Alves. - Piracicaba, 2000. \\ $127 \mathrm{p}$.
}

Tese (doutorado) - Escola Superior de Agricultura Luiz de Queiroz, 2000. Bibliografia.

1. Agricultura 2. Brasil 3. Crescimento econômico 4. Desenvolvimento econômico 5. Economia agricola 6. Financiamento T. Título

CDD 338.1 
“Pedro e João iam subindo ao templo para rezar à hora nona. Nisso levavam um homem que era coxo de nascença e que punham todos os dias à porta do templo, chamada Formosa, para que pedisse esmolas aos que entravam no templo. Quando ele viu que Pedro e João iam entrando no templo, implorou deles uma esmola. Pedro fitou nele os olhos, como também João, e lhe disse: "Olha para nós". Ele olhou com atenção, esperando receber deles alguma coisa. Pedro porém disse: "Não tenho nem ouro nem prata, mas o que tenho, eu te dou: em nome de Jesus Cristo Nazareno, levanta-te e anda!". (At 3, 1-6) 
Ah... as janelas, se elas soubessem que, além de imagens de chuva, noite, pássaros e vento, entardecer e amanhecer, passam também nossas próprias. Sonhos, lembranças, projetos, passado, futuro... quantas vezes deparei comigo e com os meus na imensidão do outro lado das janelas... (A.F.A.) 
A

Manoel, Antônio e Isabel, In memorian

Elídia

José e Áurea

Daniela

Dú, Leu e Amanda

Aqueles que continuam sem ter ou ainda acreditam que não têm chance

Dedico 


\section{Agradecimentos}

A DEUS, que tudo ronda, acompanha, permite;

Aos meus pais, José Alves Neto e Áurea Aparecida Florindo Alves, cujo incentivo e exemplo desde meus primeiros passos foram decisivos em minha formação, tanto acadêmica quanto pessoal;

A Daniela R. Verdolin, "Guerreiros são pessoas, tão fortes, tão frágeis...são meninos, no fundo do peito. Precisam de um descanso, ... de um remanso...";

Ao Prof. Paulo Cidade, que de exemplo de vida acadêmica se tornou, também, grande e admirado amigo, pela honra de ter trabalhado sob sua eficiente e segura orientação;

Aos professores G. E. Schuh, Joaquim B. S. Ferreira Filho, Joaquim J. M. Guilhoto e Mirian R.P. Bacchi, pela leitura, comentários e sugestões, valiosos ao longo da elaboração desta tese;

A Alexandre L. Mendonça de Barros, Antônio Carlos Moretto \& Rossana L. Rodrigues, Carlos J. C. Bacha, Rodolfo Hoffmann e Ricardo L. Lopes;

A Antônio C. de Campos, José L. Parré, Márcia Istake e Rosemari Lima, pelo apoio logístico na ponte rodoviária e eletrônica Maringá-Piracicaba;

A Francisco R. Evangelista (BNB), José G. Gasques (IPEA), Marcelo Braga (UFV) e Roberto O. Ramos (IBGE), pelo apoio e presteza;

A João Carlos V. Oliveira, pelo apoio novamente decisivo na lida com os dados;

Ao Departamento de Economia, Sociologia e Administração da ESALQ/USP, pela oportunidade deste curso e pela receptividade, disponibilidade e competência de seu corpo docente;

Às meninas da Biblioteca Angélica, Ligiana, Luciane e Silvana e a todos os funcionários do DEAS, Cristiane, Elenice, Helena, Maielli, Márcia, Maria Helena, Pedro e Valdeci: companheirismo e profissionalismo essenciais à minha estadia em Piracicaba;

Ao Departamento de Economia, ao Centro de Ciências Sociais Aplicadas, à Pró-Reitoria de Pesquisa e Pós-Graduação e à Universidade Estadual de Maringá, pelo apoio irrestrito às minhas atividades concomitantes de docente e discente;

Aos meus colegas da UFV, do CPG-EA e da ESALQ, pela bela, digna e honrosa convivência;

Ao CNPq e à CAPES, pelo apoio financeiro.

Mais uma vez, permitam-se fazer um agradecimento sem citar os demais nomes que deveriam ser colocados aqui. Motivo forte para isso é que continuo acreditando que um sem número de pessoas tão especiais com quem convivi durante todos esses anos o são de fato, sem esperar reconhecimento por isso. Felizmente minha jornada permite dizer que este mundo ainda tem muita gente boa, honesta, bem intencionada. E isso anima a “Tocar em Frente". O segundo motivo é que, graças a DEUS, é tanta gente que seria difícil não cometer algum equívoco (afinal, professor não erra, no máximo, se equivoca). Só digo uma coisa: se você está lendo isso e acha que de alguma forma seu nome poderia estar aqui, saiba que por certo está gravado em outro lugar. Paz e bênçãos. 


\section{SUMÁRIO}

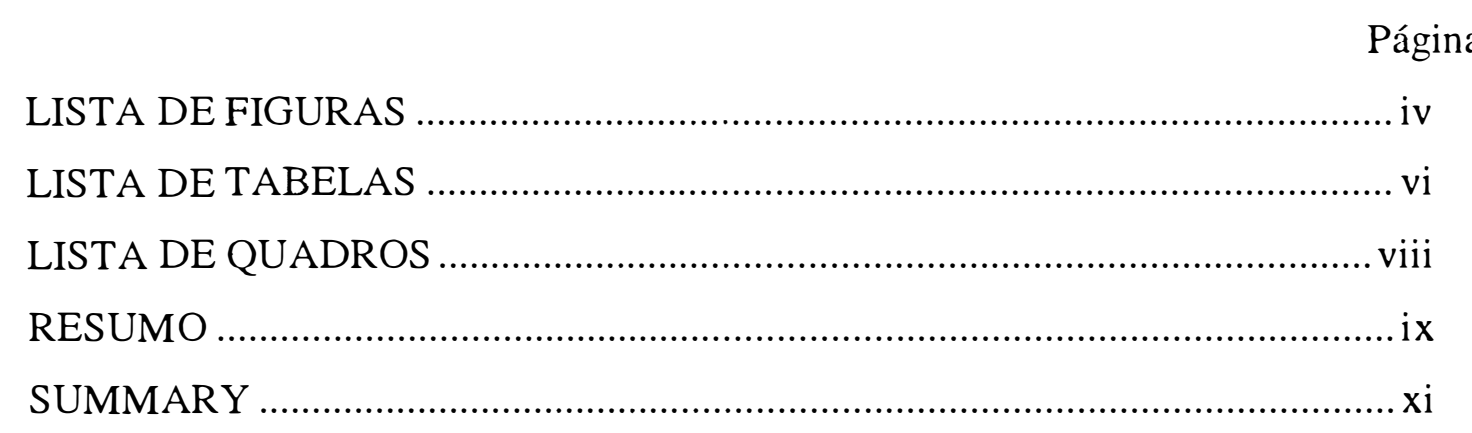

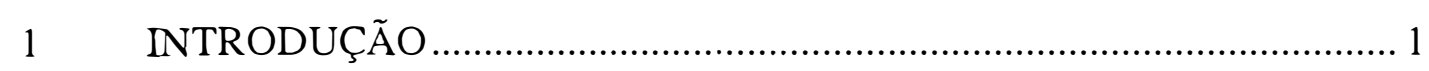

1.1 Exemplos de transferências de recursos entre a agricultura e outros

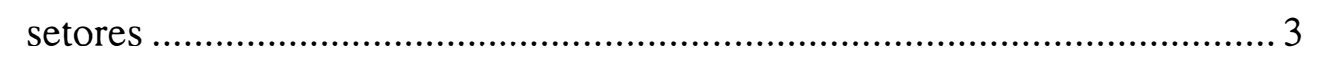

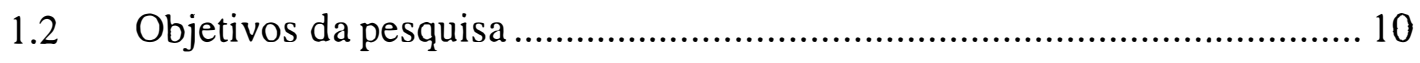

2 AGRICULTURA E DESENVOLVIMENTO ECONÔMICO: dos papéis clássicos à interdependência com outros setores.......................... 11

2.1 A importância da agricultura para o crescimento econômico .................... 11

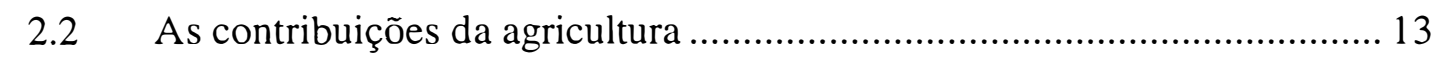

2.3 Participação relativa da agricultura no produto e no emprego .................. 17

2.4 Retrospectiva das políticas agrícolas no Pós-Guerra................................ 24

3 MÉTODOS DE ESTIMAÇÃO DO EXCEDENTE AGRÍCOLA ….......... 27

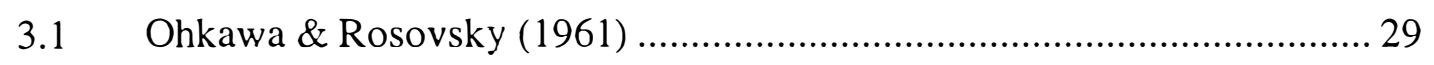

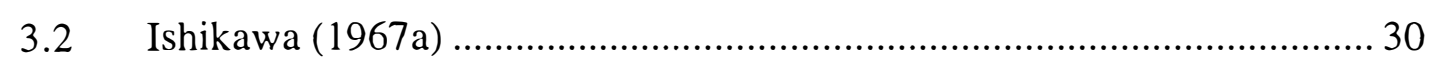

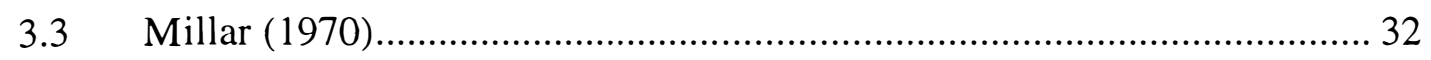

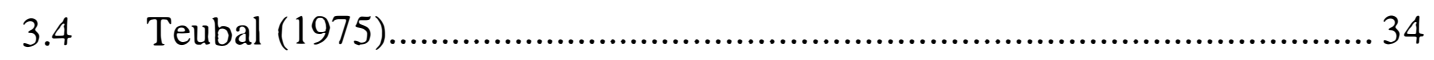

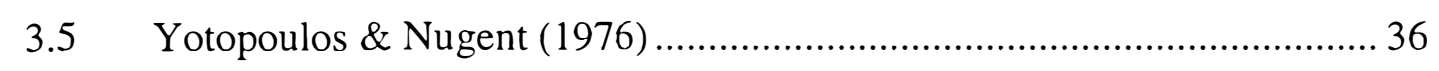


Página

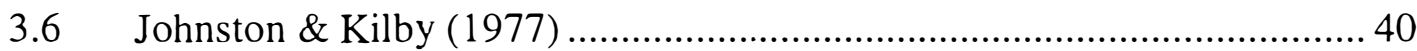

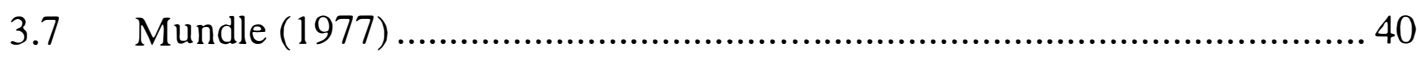

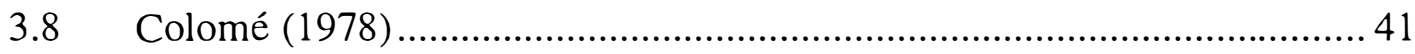

3.9 Mundle \& Ohkawa (1979) ….............................................................. 42

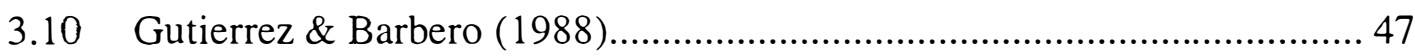

3.11 Morrison \& Thorbecke (1990) ........................................................... 48

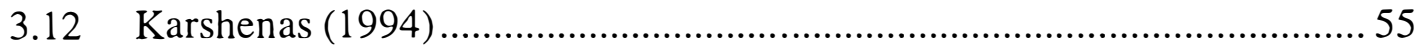

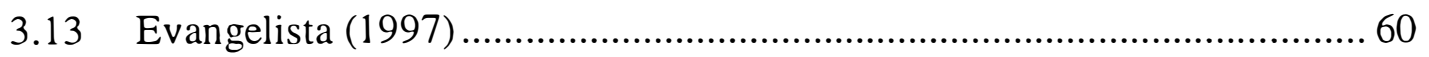

3.14 Considerações adicionais sobre as abordagens metodológicas ................. 62

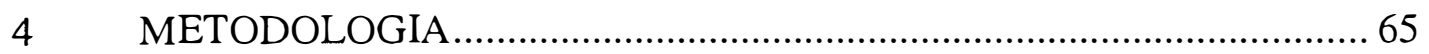

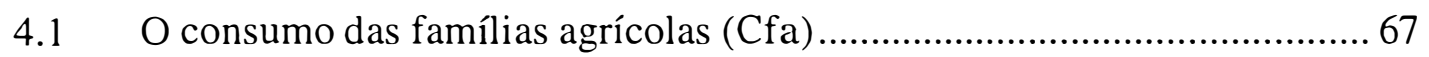

4.2 Os investimentos no setor agrícola (Ia) ............................................. 70

4.2.1 Série com base na variação do estoque de tratores e o investimento da Matriz de Insumo-Produto de 1980 (Ia1)........................................ 72

4.2.2 Série com base na variação das vendas de tratores e o investimento da Matriz de Insumo-Produto de 1980 (Ia2) .......................................... 75

4.2.3 Série com base na variação das vendas de tratores e o investimento dos Censos Agropecuários (Ia3) ......................................................... 76

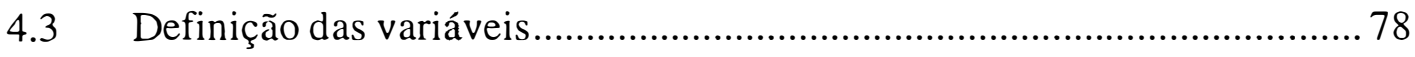

5 RESULTADOS E INTERPRETAÇÃ O ............................................... 80

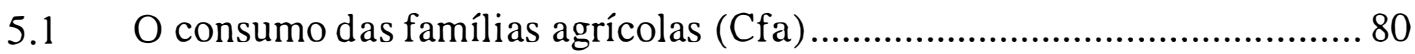

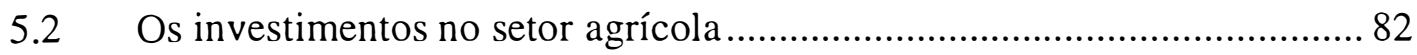

5.3 O excedente líquido do setor agrícola (NSa) ........................................ 85

5.4 O R1 - Excedente Financeiro do setor agrícola com base na estimativa de investimento Ia 1 ............................................................ 92

5.4.1 Transferências visíveis (RV1) e invisíveis (RI1) relativas ao excedente financeiro R1 f................................................................. 94 
Página

5.5 O R2 - Excedente Financeiro do setor agrícola com base na estimativa de investimento Ia 2 ...................................................... 98

5.5.1 As transferências visíveis (RV2) e invisíveis (RI2) relativas ao excedente financeiro R2 …......................................................... 101

5.6 O R3 - Excedente Financeiro do setor agrícola com base na estimativa de investimento Ia3 ....................................................... 102

5.6.1 As transferências visíveis (RV3) e invisíveis (RI3) relativas ao excedente financeiro R3 .............................................................. 104

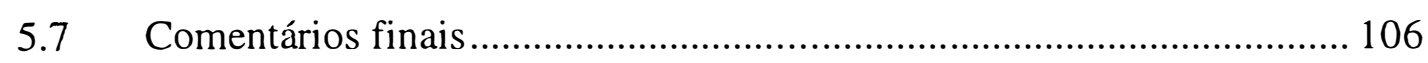

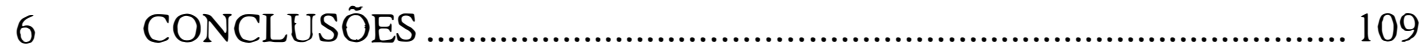

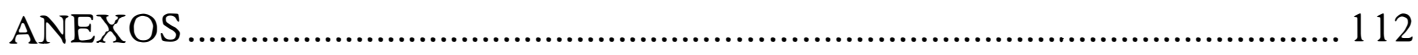

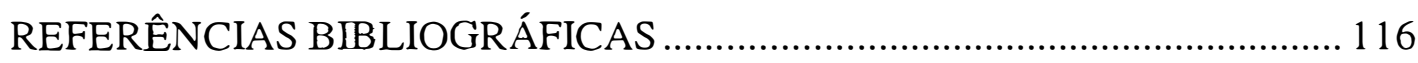




\section{LISTA DE FIGURAS}

Página

Figura 1. Possíveis divisões setoriais da economia

43

Figura 2. Variações nos investimentos, nas vendas de tratores e estoque de tratores de 1980 a 1985 e de 1985 a 1995.

Figura 3. Evolução do valor adicionado do setor agrícola (VAa) e do consumo da famílias agrícolas (Cfa) de 1980 a 1998 (US\$ milhões de 1998)

Figura 4. Evolução das estimativas de investimento no setor agrícola, Ial, Ia2 e Ia3, de 1980 a 1998 (US\$ milhões de 1998)

Figura 5. Evolução do valor adicionado do setor agrícola (VAa), consumo das famílias agrícolas (Cfa) e excedente líquido (NSa), de 1980 a 1998 (US\$ milhões de 1998).

Figura 6. Evolução da relação entre excedente líquido/valor adicionado do setor agrícola (NSa/VAa) e de excedente líquido/valor adicionado total (NSa/VAt), de 1980 a 1998 (\%).

Figura 7. Evolução do excedente líquido (NSa), do excedente financeiroRl e do investimento Ial de 1980 a 1998 (US\$ milhões de 1998) 93

Figura 8. Evolução das relações excedente líquido/valor adicionado do setor agrícola (NSa/VAa), excedente financeiro $\mathrm{R} 1 / \mathrm{valor}$ adicionado do setor agrícola (R1/VAa), excedente líquido/valor adicionado total (NSa/VAt) e excedente financeiro R1/valor adicionado do setor agrícola (R l/VAt), de 1980 a 1998 (\%),............. 94

Figura 9. Evolução dos termos de troca IPR/IPP de 1990 a 1998 ..................... 96

Figura 10. Evolução das transferências invisíveis (RIl), visíveis (RVl), totais (RVIl) e do excedente financeiro Rl de 1990 a 1998 (US\$ milhões de 1998). 
Página

Figura 11. Evolução do excedente líquido (NSa), do excedente financeiro R2 e do investimento Ia2 de 1980 a 1998 (US\$ milhões de 1998)

Figura 12. Evolução das relações excedente líquido/valor adicionado do setor agrícola (NSa/VAa), excedente financeiro R2/valor adicionado do setor agrícola (R2/VAa), excedente líquido/valor adicionado total (NSa/VAt) e excedente financeiro R2/valor adicionado do setor agrícola (R2/VAt), de 1980 a 1998 (\%).

Figura 13. Evolução das transferências invisíveis (RI2), visíveis (RV2), totais (RVI2) e do excedente financeiro R2 de 1990 a 1998 (US\$ milhões de 1998).

Figura 14. Evolução do excedente líquido (NSa), do excedente financeiro R3 e do investimento Ia3 de 1980 a 1998 (US\$ milhões de 1998) 103

Figura 15. Evolução das relações excedente líquido/valor adicionado do setor agrícola (NSa/VAa), excedente financeiro R3/valor adicionado do setor agrícola (R3/VAa), excedente líquido/valor adicionado total (NSa/VAt) e excedente financeiro R3/valor adicionado do setor agrícola (R3/VAt), de 1980 a 1998 (\%).......... 104

Figura 16. Evolução das transferências invisíveis (RI3), visíveis (RV3) e totais (RVI3), do excedente financeiro R3 de 1990 a 1998 (US\$ milhões de 1998). 105 


\section{LISTA DE TABELAS}

Página

Tabela 1. Alocações setoriais de produção em 1965, 1980 e 1990 e de

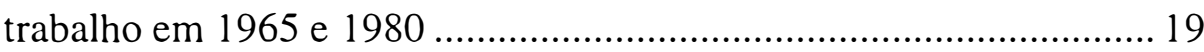

Tabela 2. Características estruturais da agricultura brasileira (em \%) ............... 20

Tabela 3. Taxas médias anuais de crescimento dos diferentes setores nos países subdesenvolvidos, de 1965 a 1988 (em \%)............................. 22

Tabela 4. Estoque e venda de tratores de roda no Brasil, de 1980 a 1998 (unidades)

Tabela 5. Valores e variações dos investimentos, vendas de tratores e estoque de tratores, 1980, 1985 e 1995.

Tabela 6. Evolução do valor adicionado total adicionado total (VAt) e do setor agrícola (VAa), do consumo total (Ct) e do setor agrícola (Cfa), das diferentes versões de investimentos no setor agrícola (Ial, Ia2 e Ia3), do Excedente Agrícola Líquido (NSa) e das diferentes versões do Excedente Financeiro do setor agrícola (R1, R2 e R3), de 1980 a 1998 (US\$ milhões de 1998) e as proporções em relação aos valores adicionados (\%).

Tabela 7. Evolução do investimento Ia1, Ia2 e Ia3 de 1980 a 1998 (US\$ milhões de 1998)

Tabela 8. Evolução do Índice de Preços Recebidos pelos agricultores (IPR), Índice de Preços Pagos (IPP), IGP-DI e dos termos de troca (IPR/IPP) de 1990 a 1998.

Tabela 9. Evolução das transferências invisíveis (RI1), visíveis (RV1) e totais (RVI1), de excedente financeiro R1 (US\$ milhões de 1998) e das relações RI1/RVIl, RVI1/R1, RVI1/VAa e RVII/VAt de 1990 a 1998 
Tabela 10. Evolução das transferências invisíveis (RI2), visíveis (RV2), totais (RVI2), do excedente financeiro R2 (US\$ milhões de 1998) e das relações RI2/RVI2, RVI2/R2, RVI2/VAa e RVI2/VAt de 1990 a 1998.

Tabela 11. Evolução das transferências invisíveis (RI3), visíveis (RV3) e totais (RVI3), do excedente financeiro R3 (US\$ milhões de 1998) e das relações RI3/RVI3, RVI3/R3, RVI3/VAa e RVI3/VAt de 1990 a 1998

Tabela A1. Evolução do valor adicionado total adicionado total (VAt) e do setor agrícola (VAa), do consumo total (Ct) e do setor agrícola (Cfa), das diferentes versões de investimentos no setor agrícola (Ial, Ia2 e Ia3), do Excedente Agrícola Líquido (NSa) e das diferentes versões do Excedente Financeiro do setor agrícola (R1, R2 e R3), de 1980 a 1998 (R\$ milhões de 1998) e as proporções em relação aos valores adicionados (\%).

Tabela A2. Evolução do investimento Ia1, Ia2 e Ia3 de 1980 a 1998 (R\$ milhões de 1998)

Tabela A3. Evolução das transferências invisíveis (RI1), visíveis (RVl) e totais (RVI1), de excedente financeiro R1 ( $\mathrm{R} \$$ milhões de 1998) e das relações RI1/RVI1, RVI1/R1, RVI1/VAa e RVI1/VAt de 1990 a 1998.

Tabela A4. Evolução das transferências invisíveis (RI2), visíveis (RV2), totais (RVI2), do excedente financeiro R2 ( $\mathrm{R} \$$ milhões de 1998) e das relações RI2/RVI2, RVI2/R2, RVI2/VAa e RVI2/VAt de 1990 a 1998.

Tabela A5. Evolução das transferências invisíveis (RI3), visíveis (RV3) e totais (RVI3), do excedente financeiro R3 (R \$ milhões de 1998) e das relações RI3/RVI3, RVI3/R3, RVI3/VAa e RVI3/VAt de 1990 a 1998. 


\section{LISTA DE QUADROS}

Página

Quadro 1. Equações contábeis para fluxos setoriais de capital. .......................... 38

Quadro 2. Contabilidade de pagamento entre os setores agrícola e não-

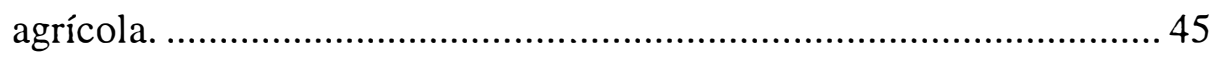

Quadro 3. Matriz de Contabilidade Social de Morrison \& Thorbecke para os Setores Agrícola e Não-Agrícola .............................................. 49

Quadro 4. Matriz de Contabilidade Social de Karshenas para os Setores Agrícola e Não-Agrícola.......................................................................56 


\title{
CONTRIBUIÇÃO DA AGRICULTURA AO CRESCIMENTO ECONÔMICO: O EXCEDENTE FINANCEIRO DE 1980 A 1998
}

\author{
Autor: ALEXANDRE FLORINDO ALVES \\ Orientador: Prof. PAULO FERNANDO CIDADE DE ARAÚJO
}

\section{RESUMO}

O objetivo desta tese é estimar o valor do excedente financeiro do setor agrícola no Brasil de 1980 a 1998. A relevância do presente estudo está na necessidade de conhecimento sobre a real contribuição da agricultura ao crescimento em um período de crise e mudanças estruturais no qual o referido setor teve melhor desempenho que o setor industrial.

São destacados ao longo do estudo a importância da agricultura para o crescimento econômico, assim como os tipos de contribuição que a mesma pode dar, a evolução de sua participação no produto e no emprego no Brasil e em outros países e algumas das políticas relacionadas à agricultura no Brasil após a Segunda Guerra Mundial. Várias abordagens metodológicas são listadas para mostrar a variedade de formas de estimar o excedente financeiro.

Uma definição de excedente financeiro baseada no instrumental Matrizes de Contabilidade Social (MCS) foi utilizada para a estimação. Assim, é possível analisar tanto o comportamento do fluxo resultante quanto seus componentes. As fontes básicas de dados são o Sistema de Contas Nacionais e as Matrizes de Insumo-Produto do Instituto Brasileiro de Geografia e Estatística (IBGE).

Foram construídas três diferentes séries de investimentos na agropecuária para possibilitar o cálculo do excedente financeiro. A primeira toma os valores do 
investimentos no setor agrícola da Matriz de Insumo-Produto de 1980 como valor básico. Os valores para os anos seguintes são obtidos aplicando ao investimento as mesmas variações verificadas no estoque de tratores nacionais de rodas. A segunda série toma o mesmo valor básico e os valores para os anos seguintes são obtidos aplicando aos investimentos a mesma variação das vendas internas de tratores nacionais de rodas. Finalmente, a terceira série toma como valores básicos para os investimentos aqueles dos Censos Agropecuários de 1980, 1985 e 1995/96 e as variações das vendas internas de tratores nacionais são aplicadas a eles para obter os valores para os demais anos.

Os resultados mostram valores positivos para excedente líquido (diferença entre o valor adicionado e o consumo das famílias no setor agrícola) e para o excedente financeiro (diferença entre o excedente líquido e os investimentos realizados no setor agrícola). O excedente líquido apresentou redução no período analisado, mas tendência crescente na década de 90. Quanto ao excedente financeiro foram feitas três estimativas, em função de diferentes estimativas para os investimentos no setor agrícola. Duas delas apresentam comportamento semelhante ao do excedente líquido enquanto a terceira apresentou tendência crescente no período analisado como um todo.

Outros resultados importantes foram os valores reais do excedente financeiro quando se consideraram as diferenças entre os preços pagos e recebidos pelos agricultores, calculados para a década de 90 . Tais valores foram notavelmente maiores que os valores reais normais de tal fluxo, mas apresentaram tendência decrescente em função da melhoria ocorrida nos termos de troca para a agricultura no mesmo período.

Finalmente, os resultados do estudo parecem ser consistentes com o comportamento da economia brasileira como um todo e do setor agrícola em particular, assim como em relação a algumas políticas, tanto macroeconômicas quanto específicas para a agricultura. Além disso, a despeito das dificuldades em comparar estudos com metodologias diferentes, os resultados para o Brasil parecem compatíveis com os obtidos em vários estudos. 


\title{
CONTRIBUTION OF AGRICULTURE TO ECONOMIC GROWTH: THE FINANCIAL SURPLUS FROM 1980 TO 1998
}

\author{
Author: ALEXANDRE FLORINDO ALVES \\ Adviser: Prof. PAULO FERNANDO CIDADE DE ARAÚJO
}

\section{SUMMARY}

The purpose of this thesis is to estimate the value of agricultural financial surplus in Brazil from 1980 to 1998 . The relevance of such a study relies on the need of improved knowledge about the real agricultural contribution to growth in a period of crisis and structural changes in which the referred sector had better performance than the industrial sector.

In the study the significance of agriculture to economic growth is stressed, as well as what kind of contribution it can give, the evolution of it's share in product and employment in Brazil and other countries and some policies related to agriculture carried out after World War II. Various methodological approaches are listed to show the variety of ways to estimate the financial surplus.

A definition of financial surplus based on Social Accounting Matrix (SAM) is used to estimate such flow. In doing so, it is possible to analyze both the behavior of resultant flow and of its components. Basic data sources are the System of National Accounts and input-output matrices, both from Instituto Brasileiro de Geografia e Estatística (IBGE).

Three different series of investments were built to make the estimation of financial surplus feasible. The first one takes the value for investments in agricultural sector reported in the official input-output matrix for 1980 as basic value. Values for 
following years are obtained applying to investment the same variation verified in stock of nationally produced wheel tractors. The second series takes the same basic value, and values for following years are obtained applying to investments the same variation of internal sales of nationally produced wheel tractors. Finally, the third series takes as basic values those from Agricultural Census carried out in 1980, 1985 and 1995/96, and variations of internal sales of nationally produced wheel tractors are applied to them to get values of investments for the other years.

Results shows positive values for Net Surplus (difference between value added of agriculture and family consumption in the sector) and for Financial Surplus (difference between Net Surplus and investments in the agricultural sector). Net Surplus diminished in the whole period, but had growing trend in the nineties. For Financial Surplus three estimates were carried out, based on the three different estimates for investment in agricultural sector. Two of Financial Surplus estimates had similar evolution to that of Net Surplus, while the third one showed positive trend for the whole period.

Other important results for the nineties are the values of Financial Surplus when terms of trade are considered. Such values were noticeably larger than normal real values of the flows, but with decreasing trend due to evolution in terms of trade favorable to the agricultural sector in the same period.

Finally, the research findings are likely to be consistent with the behavior of the Brazilian economy as a whole and of the agricultural sector, as well as with some policies, macroeconomic and specific to agriculture. Moreover, despite of difficulties in comparing different studies due to the variety of methodologies used, the results for Brazil appear to be compatible with those obtained in several studies. 


\section{INTRODUÇÃO}

A agricultura é um setor da atividade econômica de grande importância na história do Brasil. Ao contrário de outros países latino-americanos, a colonização brasileira foi baseada na agricultura, especificamente na exploração da cana-de-açúcar (Furtado, 1991). Passados vários ciclos econômicos, a agricultura voltou a ter importância no processo de industrialização e na geração de divisas, contribuindo para o crescimento econômico.

Neste estudo, pretende-se discutir os papéis e a importância da agricultura para o crescimento econômico no Brasil. Especificamente quanto aos papéis, tem-se o objetivo de mostrar qual a efetiva contribuição do setor agrícola em termos de seu excedente financeiro — procurando mensurá-lo nas décadas de 1980 e 1990 — que possa ter sido disponibilizado para os setores não-agrícolas no seu processo de crescimento. A estimativa da efetiva contribuição financeira da agricultura pode, então, servir tanto de subsídio para a formulação de políticas per se quanto para esclarecer o próprio desempenho deste setor.

A questão do fluxo de recursos entre agricultura e indústria, além de relacionada ao problema do desenvolvimento agrícola, envolve uma questão associada à formulação de políticas: qual o papel esperado do setor agrícola no financiamento do desenvolvimento econômico geral (Ishikawa, 1967a). Sabe-se que a formulação de políticas está ligada, entre outros aspectos, à existência de subsídios técnicos sobre sua viabilidade, necessidade e efeitos. Quanto ao setor agrícola brasileiro, o que se teve em sua história recente foi negligência e discriminação. Tanto que Schuh (1997) cita que, não fora a discriminação, a agricultura poderia ter contribuído de modo ainda mais 
significativo para o desenvolvimento do Brasil, o que está de acordo com Nicholls (1975) que apresenta diferentes situações teóricas quanto a densidades populacionais e formas de propriedade da terra e conclui que a subvalorização da agricultura implica dificuldades para o crescimento inicial do setor industrial.

A noção de que a agricultura tem que ajudar no processo de desenvolvimento de uma nação fez com que a mesma fosse vista somente como geradora de recursos para o resto da economia, sendo pouco expressivas as políticas direcionadas ao setor. Tal discriminação pode ter efeitos sobre o desempenho da agricultura. Segundo Stern "se alguém vê ou não a agricultura como eficiente influencia na sua percepção quanto às possíveis fontes de crescimento na agricultura e como tal crescimento pode ser atingido" (Stern, 1994, p.46). Ainda neste sentido, Schuh cita que "a compreensão de como a agricultura contribui para o desenvolvimento da economia é a chave para os investimentos neste setor e uma adequada política econômica voltada para ele" (Schuh, 1997, p.15). Além disso, para Meier (1995, p.395) "a agricultura precisa ser vista não somente como uma fonte de excedentes para sustentar a industrialização, mas também como uma fonte dinâmica de crescimento, emprego e melhor distribuição de renda". A ignorância a respeito do potencial de contribuição do setor agrícola ajuda a reforçar "a atenção quase que exclusiva dada às políticas de desenvolvimento industrial" (Evangelista, 1997, p. 102).

Segundo Mundle \& Ohkawa (1979), a mobilização de excedentes de recursos da agricultura teve uma retomada de interesse e reconhecimento como mecanismo de central importância para o desenvolvimento após a II Guerra Mundial. ${ }^{1} \mathrm{Na}$ ausência de recursos externos de larga escala, um fundo substancial de investimentos precisa ser mobilizado para financiar o desenvolvimento do setor industrial moderno, além do excedente de mão-de-obra e de produtos agrícolas. Além disso, Mellor (1985) ressalta que o crescimento acelerado da produção agrícola dos países de baixa renda pode

\footnotetext{
${ }^{1}$ Little (1982) confirma que a necessidade de crescimento agrícola teve forte ênfase a partir da década de 1960.
} 
aumentar as transferências intersetoriais de recursos e afetar as taxas relativas de formação de capital e crescimento de renda em vários setores.

Mellor (1985) comenta que existe controvérsia a respeito do fluxo de recursos entre a agricultura e outros setores nos estágios iniciais do desenvolvimento econômico. Basicamente, o autor cita autores que argumentam que deve haver entrada de recursos, pois são necessários investimentos para que a agricultura consiga suprir a crescente demanda de alimentos que acompanha o desenvolvimento industrial. Por outro lado, outros autores argumentam que deve haver saída de recursos da agricultura, devido às maiores taxas de retorno dos investimentos não-agrícolas. Tal comentário deve ser visto com cuidado, pois diferentes autores podem tratar de forma diferente o que entendem como fase de desenvolvimento econômico.

Para Gutierrez \& Barbero (1988, p.137) “o conceito de excedente financeiro de um setor econômico, particularmente do setor rural, tem um papel importante em muitos âmbitos de política econômica, pois indica se estão entrando ou saindo fundos de tal setor". Segundo esses autores, tal importância está associada à idéia freqüente na literatura que fundos, em economia com baixas taxas de investimentos, devem provir do setor agropecuário. Isto está de acordo com Teubal (1975), para o qual a noção da importância quantitativa do excedente financeiro, assim como sua evolução, pode ajudar a compreender melhor os efeitos econômicos das políticas agrícolas alternativas.

\subsection{Exemplos de transferências de recursos entre a agricultura e outros setores}

Neste item são apresentados exemplos de trabalhos que tratam da transferência de recursos entre a agricultura e outros setores da economia no Brasil e em outros países. Quanto à agricultura no Brasil, sabe-se que a mesma tem várias faces e, além disso, a definição e justificação de políticas depende das melhores informações possíveis, e não podem ser pautadas meramente em especulações. Como exemplo de trabalhos que ajudaram a esclarecer questões deste tipo tem-se o de Evangelista (1997) que mostrou 
que a agricultura nordestina "exportou" recursos de 1965 a 1974 e de 1984 a 1993. Esta constatação pode ser para muitos surpreendente, embora Martin (1976), examinando as transações interregionais do Nordeste, São Paulo e Brasil excluindo São Paulo, já tivesse mostrado que o Nordeste ajudou a financiar a balança comercial negativa de São Paulo no período $1947-73^{2}$ e, então, parte de seu desenvolvimento industrial, visto que o maior componente das importações paulistas era de bens de capital. Deve-se notar que a proporção de tal contribuição caiu a partir da década de 1960.

Martin (1976) cita que Baer $\left(1965^{3}\right)$ apontou as conseqüências regionais da discriminação contra a agricultura. Isto porque a indústria se concentrava no Sudeste, fazendo com que a mudança nas relações de troca provocasse transferências entre os setores agrícolas das outras regiões e o setor industrial do Sudeste. O próprio Martin, embora tenha focalizado sua análise na região Nordeste, relata que efeitos semelhantes ocorreram em outras regiões do Brasil.

Baer (1996) cita que havia argumentos de as políticas de intensificação da industrialização por substituição de importações colaborarem para concentração de renda no Sudeste pois, ao mesmo tempo que o Nordeste exportava produtos primários, era obrigado a importar manufaturados do Centro-Sul a um preço maior que o dos bens importados. Assim, uma queda nas relações de troca para o Nordeste ajudou a subsidiar a industrialização do Centro-Sul. No entanto, analisando o período 1948-68, existem evidências de tal tendência somente na década de 50. Houve reversão no início da década de 60 devido a uma taxa de câmbio mais favorável para os produtos exportados pelo Nordeste e seus respectivos preços em relação ao nível geral de preços do país. ${ }^{4}$

Outra análise mostrada por Baer (1996) refere-se às transferências via mecanismos fiscais. De acordo com Albuquerque \& Cavalcanti ${ }^{5}$, citados por Baer, tal

\footnotetext{
${ }^{2}$ A balança comercial do Nordeste foi positiva para todo o período, com exceção de 1952 e a de São Paulo negativa, com exceção de 1947-50, 1953 e 1956 (Martin, 1976).

${ }^{3}$ Ver também Baer (1996) p.307.

${ }^{4}$ Análise semelhante aparece em Baer (1965).

s ALBUQUERQUE, R.C.; CAVALCANTI, C.V. Desenvolvimento regional do Brasil. Brasília: IPEA, 1976. p.123-5. (Série Estudos para o Planejamento, 16).
} 
transferência de recursos para o Nordeste (gastos federais + transferências + incentivos fiscais - arrecadação fiscal) aumentou de 4,4\% do PIB regional para mais de $6 \%$ entre o início dos anos 60 e a primeira metade da década de 70. Não é possível, no entanto, comparar com os resultados de Evangelista, pois Baer faz as análises citadas nos dois últimos parágrafos separadamente, não mostrando o resultado líquido. Será possível verificar adiante que a análise de Evangelista é mais completa que as de Baer (1965, 1996) e Martin (1976), pois estas últimas referem-se basicamente aos efeitos de variações nos termos de troca.

Nicholls (1964) aponta como importante lição do desenvolvimento de países ocidentais para outros países a de que a existência de um excedente agrícola é uma précondição para o desenvolvimento industrial. Para Schuh (1975), a industrialização em São Paulo apoiou-se no capital e talento empresarial provenientes do setor agrícola. ${ }^{6}$ Inicialmente a mobilização de capital foi realizada pelo setor bancário ou pelos próprios empresários agrícolas (espontaneamente). Mais tarde, parte do excedente agrícola foi confiscada para alocação nos setores industrial e de infra-estrutura. Através da restrição da quantidade de café no mercado, por exemplo, conseguiu-se um aumento nos preços e na receita com esta cultura, sendo que "a maior parte dos recursos oriundos dessa política foram passados para o setor industrial, tornando-se uma fonte importante de capital de desenvolvimento" (Schuh, 1971, p.47).

Para o país, Oliveira (1984, p.817), fez algumas simulações e concluiu que:

"os resultados dos exercícios realizados...suportam totalmente a hipótese de que a agricultura contribuiu de forma significativa para o crescimento geral da economia brasileira no período do pós-guerra. A participação da agricultura na renda interna foi largamente subestimada e as transferências de renda da agricultura por meio de taxação implícita? foram, na verdade, bastante significativas, quando medidas tanto em termos da renda agrícola como da taxa de formação do capital nacional."

\footnotetext{
${ }^{6} \mathrm{O}$ papel da agricultura na industrialização também é destacado por Veiga (1975).

7 "Transferência de renda intersetorial resultante de todas as distorções que atuam sobre a estrutura de preços relativos, através do mercado de insumos comprados" (Oliveira, 1984, p.774).
} 
Quanto aos estudos em outros países, tem-se vários exemplos. Os resultados dos trabalhos de Karshenas $(1990,1994)$ contrariam pressuposição, predominante na literatura, a respeito da direção do fluxo líquido de recursos saindo da agricultura do Irã no período 1960-1977 em função do viés em relação à industrialização e negligência quanto ao setor agrícola. As estimações do autor indicaram que no referido período, o que houve foi uma entrada líquida de recursos na agricultura, e em magnitude relativamente grande.

De acordo com Ohkawa \& Rosovsky (1961), um modelo que descrevesse o desenvolvimento econômico do Japão no período 1878-1940 teria a agricultura como um setor provedor de produtos agrícolas, força de trabalho e com alta propensão a poupar. Para estes autores, a agricultura contribuiu para a urbanização e industrialização japonesa no período 1878-1917, pois a oferta de alimentos acompanhou a evolução da demanda, evitando assim pressão inflacionária. ${ }^{\circledR}$ Além disso, contribuiu com a produção de excedentes exportáveis (seda e chá, por exemplo). Analisando o período 1888-1937, Mundle \& Ohkawa (1979) encontraram, também para o Japão, excedente agrícola (de comércio) positivo - diferença entre bens e serviços enviados e recebidos pelo setor agrícola - exceção somente para um período de estagnação agrícola na década de 20 (mais especificamente de 1923-27 a 1928-32) e excedente de poupança positivo diferença entre saída e entrada de poupança no setor agrícola — em todo o período. Esses autores relatam que o excedente financeiro foi positivo em Taiwan (1890-1930) e positivo na maioria dos anos na Índia entre 1951 e 1971.

Mundle \& Ohkawa (1979) chamam a atenção, no entanto, para o fato de a magnitude do excedente depender de sua participação no PIB total e no PIB agrícola.

\footnotetext{
${ }^{8}$ Embora Lewis (1995b) cite mais tarde que nos países menos desenvolvidos, a produção de alimentos não acompanhou o aumento da demanda, causando uma série de outros problemas. As causas apontadas pelo autor para esta falha são aumento da população, atraso no desenvolvimento tecnológico associado às culturas alimentares, falhas nos serviços de extensão e suprimento de insumos modernos, inadequado investimento em infra-estrutura rural, falta de política consistente de reforma agrária e, finalmente, a queda nos termos de troca para os produtos agrícolas, e m função do grande aumento de produtividade nos EUA ou das políticas de contenção dos preços agrícolas.
} 
Nesse sentido, dizem: "é certo que os fluxos da agricultura para o setor não-agrícola do Japão não tiveram um papel decisivo no financiamento do desenvolvimento deste último setor" (p.261). Segundo os autores, a agricultura contribuiu somente para que o investimento no setor não-agrícola fosse mantido em nível mais alto que a sua taxa de poupança.

Mundle (1977) verificou que o setor a grícola foi comprador/importador líquido de bens de consumo no período de 1950 a 1970 na Índia. Em relação aos bens de produção, verificou-se saída líquida (a agricultura foi um exportador líquido) em todo o período. Em termos reais, o resultado líquido foi que do início do período até 1953-54 e de 1966-67 até 1970-71, houve saída líquida de recursos, enquanto de 1954-55 até 196566 houve entrada. O autor chama atenção para que os valores positivos e negativos dependem do ano base escolhido, mas ficam claras as mudanças de tendência importador-exportador-importador. Esse resultado é semelhante ao obtido por Ishikawa (1967b) que verificou, na China, mudança para excedente de importações a partir de 1955 (período de análise de 1950 a 1959), e com tendência de aumento, sendo que colaboraram para esta mudança um repentino aumento de bens de produção e investimentos governamentais na formação de capital.

Um fluxo líquido de capital da agricultura parece ter contribuído para o crescimento do produto e do emprego não-agrícola, tanto em Formosa quanto no México (Johnston \& Kilby, 1977). Em Formosa, a expressiva saída líquida de recursos da agricultura foi possível graças a aumentos na produção agrícola associados à pequena elevação no uso de insumos comprados. No México, embora tenha havido uma transferência relativamente pequena em relação a Formosa, a mesma também esteve relacionada a uma substancial aceleração do crescimento agrícola, fazendo com que a poupança do setor fosse maior que os investimentos ali realizados.

Os trabalhos de Teubal $(1971$; 1975) e Colomé (1978), apesar de diferirem quanto às magnitudes, apresentam tendências decrescentes para o excedente financeiro agrícola argentino no período 1950-67. Colomé (1978), estudando o mesmo período, 
mas utilizando metodologia diferente, verificou que há três subperíodos de três anos apresentando valores negativos, e que coincidem com as fases de retenção do ciclo pecuário, com fortes acumulações de estoques. Segundo este autor, as estimativas de Teubal superestimam o excedente financeiro agropecuário argentino de 1950 a 1967. Colomé estima uma transferência acumulada no período de 62.791 milhões de pesos de 1960, ao passo que para Teubal o valor foi de 497.365 milhões da mesma moeda. Em estudo de 1970 a 1985, Gutierrez \& Barbero (1988) encontraram tendência crescente para o excedente financeiro do setor agropecuário argentino, começando com valores negativos para o início da década de 70 e passando a valores positivos a partir da década de 80 .

Mellor (1985) apresenta exemplos de fluxos de recursos em diferentes países:

- Taiwan: grande e contínua transferência de recursos da agricultura para outros setores no período de 1895 até 1960;

- Japão: a agricultura forneceu a maior porção do capital para os estágios iniciais do desenvolvimento, via investimentos diretos dos agricultores, impostos sobre a terra e rebaixamento dos preços agrícolas via i mportações na década de 20 quando houve estagnação da agricultura;

- Grã-Bretanha: transferência da agricultura, também nos estágios iniciais do desenvolvimento industrial, via pagamentos de aluguéis de terra, impostos e também via termos de troca contra a agricultura e m função de importações a preços baixos;

- França: transferência de recursos para a agricultura, via relações de troca favoráveis ao setor agrícola;

- União Soviética: transferência de capital da agricultura;

- Índia: recursos para a agricultura através de gastos do governo maiores que a arrecadação, termos de troca internos favoráveis à agricultura e transferências privadas. 
Ishikawa (1967a) afirma que, apesar das dificuldades de mensuração, é possível ter havido entrada líquida de recursos ou mudança de saída para entrada líquida nos três países estudados da Ásia, durante o processo de desenvolvimento agrícola. Os países e os respectivos períodos são: Índia (1951/52 a 1961/62), China (1953 a 1956) e Taiwan (1950 a 1962).

Aspecto importante é a capacidade de geração de excedentes, que corresponde à poupança agrícola. Daí, podem derivar basicamente duas possibilidades de encarar o fato: uma delas refere-se a quanto desta poupança pode ser usado para o financiamento de outros setores da economia. Outro aspecto, levantado por Alves et al. (1996) é que a poupança agrícola representa capacidade de investimento na economia, quer seja no setor agrícola ou não. Este argumento pode ser reforçado, por exemplo, pelo fato de que, no período analisado por Guilhoto et al. (1994) e Furtuoso \& Guilhoto ${ }^{9}$ (no prelo) 1959 a 1995 - a agricultura foi um setor-chave da economia brasileira. Ou seja, não somente a parte da poupança agrícola investida fora da agricultura merece destaque e estudo, mas também o valor total desta poupança, o que inclui a porção investida no próprio setor.

No Brasil, tanto a redução nos efeitos do viés industrial quanto o surgimento de mecanismos de incentivo à produção agrícola, principalmente o crédito subsidiado, deixam dúvidas sobre a contribuição líquida do setor agrícola. Além disso, a análise de fluxos intersetoriais pode levar até mesmo a inferências sobre a utilização dos recursos. Karshenas (1994) aponta que os problemas da agricultura iraniana podem estar associados mais à ineficiência no uso de recursos no setor do que aos resultados do viés industrial. Para o autor, isso pode ter ocorrido também em outros países da Ásia.

9 FURTUOSO, M.C.O.; GUILHOTO, J.J.M. A estrutura produtiva da economia brasileira e o agronegócio: 1980 a 1995. In: MONTOYA, M.A. (Ed.) Aspectos setoriais no agronegócio brasileiro. EUPF/Editora da UFRS. /No prelo/. 


\subsection{Objetivos da pesquisa}

Apesar da variedade de situações, sabe-se que mesmo com o declínio dos incentivos creditícios na década de 1980, a agricultura brasileira apresentou desempenho favorável, principalmente em termos de produtividade (Gonzalez \& Costa, 1998; Mendonça de Barros, 1999). Assim sendo, trabalha-se com a hipótese do excedente financeiro do setor agrícola ser positivo e crescente no período em análise.

Tendo em vista a importância da agricultura para o Brasil e as diferentes fases que a mesma atravessou, o presente estudo tem como objetivo geral medir a contribuição do setor agrícola brasileiro, em termos de excedente financeiro, para o crescimento econômico nas décadas de 80 e 90. Como objetivos específicos, procurar-se-á:

- estimar séries de consumo e investimentos no setor agrícola no período de 1980 a 1998, informações necessárias aos cálculos dos excedentes;

- medir a quantidade excedente gerada pela agricultura brasileira nas décadas de 1980 e 1990;

- medir a quantidade excedente gerada pela agricultura brasileira nas décadas de 1980 e 1990 em função de alterações nas relações de troca (transferências invisíveis); e,

- analisar a evolução de tal contribuição e de seus principais componentes. 


\section{AGRICULTURA E DESENVOLVIMENTO ECONÔMICO: dos papéis clássicos à interdependência com outros setores}

Neste Capítulo discute-se resumidamente a evolução da percepção de como a agricultura está relacionada ao desenvolvimento econômico. Para tanto são apresentados exemplos de teorias e fatos. O Capítulo apresenta uma descrição da importância da agricultura ao longo dos estágios de desenvolvimento, seguida de seus papéis clássicos, de novas funções e da percepção da interdependência que existe entre os setores agrícola e não-agrícola.

\subsection{A importância da agricultura para o crescimento econômico}

A idéia de que a agricultura fornece um excedente disponível para a provisão de capital para outros setores é quase tão velha quanto a Economia (Teubal, 1971). Aparece, por exemplo, na escola Fisiocrata a idéia do "produit net" como um excedente essencial para o processo de crescimento da economia. Segundo este autor, mesmo de acordo com os economistas clássicos, como Smith e Ricardo, para os quais a acumulação de capital era possível graças aos excedentes agrícola e industrial, a agricultura seria o principal fornecedor de fundos para tal acumulação. Stern (1994) também faz alusão aos clássicos. Cita, por exemplo, Ricardo e Malthus, para os quais o excedente agrícola (em termos de alimentos e trabalhadores) era crucial para o crescimento do setor não-agrícola. No final da década de 60, Ishikawa (1967b) afirma que a idéia de que para o progresso dos países subdesenvolvidos seriam necessários fundos do setor agrícola já seria algo de senso comum. 
A importância da agricultura também pode ser verificada nos modelos de crescimento econômico. Autores como Teubal (1971), Silva (1982) e Stern (1994), apresentam vários modelos que enfatizam a relação entre agricultura e o restante da economia. Silva (1982), analisando alguns modelos teóricos sobre a interação da agricultura e o conjunto do sistema econômico, como Lewis ${ }^{10}$, Ranis \& Fei ${ }^{11}$, Schultz ${ }^{12}$ e Hayami \& Ruttan ${ }^{13}$, chama a atenção para o fato de que a maioria das abordagens tem caráter unidirecional, isto é, pouca ênfase é atribuída aos objetivos do próprio setor agrícola. Yotopoulos \& Nugent (1976) também consideram os modelos dualistas e de crescimento em estágios como tentativas de sistematizar a discussão sobre a mudança no papel $^{14}$ da agricultura no processo de desenvolvimento. Para eles, boa parte da literatura trata as contribuições da agricultura como unidirecionais, falhando em considerar as complementaridades entre setores.

Existem diversos exemplos deste tipo de tratamento da agricultura. Hirschman ${ }^{15}$, citado por Staatz \& Eicher (1985), afirma que os investimentos na indústria deveriam ter prioridade, uma vez que as ligações entre setores da indústria e o resto da economia são mais expressivas que as ligações da agricultura. ${ }^{16}$ Outro exemplo é a afirmação de Owen (1975, p.62):

..."nas nações em desenvolvimento, a ênfase deveria ser colocada, claramente, não na equidade imediata entre as rendas dos dois setores, mas na maximização da taxa de crescimento da agricultura e no desvio imediato, o mais rápido possível, desse aumento para proteção e suporte do setor não-agrícola emergente"...

${ }^{10}$ LEWIS, W.A. Economic development with unlimited supplies of labor. The Manchester School of Economics and Social Studies, v.22, p.139-92, May 1954.

${ }^{11}$ RANIS, G.; FEI, J.C.H. A theory of economic development. American Economic Review, v.51, n.4, p.533-65, Sep. 1961.

${ }^{12}$ SCHULTZ, T.W. A transformação da agricultura tradicional. Rio de Janeiro: Zahar, 1965. 207p.

${ }^{13}$ HAYAMI, Y.; RUTTAN, V.W. Agricultural development: an international perspective. Baltimore: Johns Hopkins, 1971. 367p.

${ }^{14}$ Timmer (1988) tenta fazer distinção entre contribuição e papel da agricultura, argumentando que o segundo termo é menos impositivo. Para o presente estudo, no entanto, o que interessa é o resultado líquido das transferências intersetoriais de recursos. Assim, os termos são tidos como sinônimos.

${ }^{15}$ HIRSCHMAN, A.O. A generalized linkage approach to development with special reference to staples. Economic Development and Cultural Change, v.25, p.67-98, 1977.

${ }^{16}$ Lembre que tal afirmação contraria os resultados obtidos por Guilhoto et al. (1994) e Furtuoso \& Guilhoto (Op. cit.) para o Brasil, citada no Capítulo anterior. 
No entanto, Mundle (1977) chama a atenção para o fato de ser a drenagem de recursos da agricultura uma forte restrição ao desenvolvimento da agricultura, que depende da acumulação de excedentes.

Para Stern (1994), a agricultura pode ser fonte de crescimento e renda. Cita, como exemplos, os casos de aumento de produtividade de arroz na Ásia no final da década de 1960 e particularmente na China, no início dos anos oitenta, onde as reformas institucionais e econômicas, que começaram pela agricultura, causaram aumento expressivo de produção e produtividade. Além disso, expressiva parcela da população de países em desenvolvimento depende da agricultura. Particularmente no Brasil, isto é verdadeiro em várias regiões, uma vez que a produção industrial é bastante concentrada entre nós (Baer, 1996; IBGE, 1999a).

\subsection{As contribuições da agricultura}

Diferentes autores têm colaborado para o entendimento do papel da agricultura no desenvolvimento. Kuznets (1964) classifica a contribuição da agricultura em três tipos: em produto, em mercado e em fatores. A contribuição em produto representa o crescimento do produto dentro do próprio setor que, obviamente, colabora para o crescimento do produto nacional. A contribuição em mercado representa o fato de poder contribuir para o crescimento de outros setores ou para a participação da economia como um todo no mercado internacional - inclui, por exemplo, troca de bens (inclusive insumos) com outros setores domésticos ou externos. Essa contribuição pode ser tão mais expressiva quanto maior for o impacto que tenha nos setores com os quais o comércio é realizado.

O terceiro tipo de contribuição refere-se à transferência ou empréstimo de recursos a outros setores. Os recursos, neste caso, podem ser capital e trabalho. As transferências de capital podem ser compulsórias, por exemplo, via taxação, ou espontâneas, via empréstimo ou utilização direta de poupança originada no setor 
agrícola para financiar o crescimento de setores não-agrícolas. Essa contribuição em fator engloba aspectos destacados também por Ranis \& Fei ${ }^{17}$ citados por Teubal, para os quais "o excedente agrícola e a força de trabalho agrícola representam os dois principais recursos reais que são fornecidos pelo setor agrícola de subsistência para alimentar a expansão do setor industrial" (Teubal, 1971, p.15).

A natureza das transferências, voluntárias ou involuntárias, também é ressaltada por Myint ${ }^{18}$, citado por Evangelista (1997). O primeiro caso, segundo Myint, refere-se a transferências que ocorrem no longo prazo e em conformidade com mudanças estruturais na economia. No curto prazo, para ele, as transferências são compulsórias e resultado de políticas deliberadas. A distinção de Myint é interessante pois os dois tipos citados ocorreram no Brasil e foram importantes no processo de industrialização, embora a distinção entre longo e curto prazo possa ser questionável. Meier (1995) também cita que, além das poupanças voluntárias para a formação de capital, pode haver transferências compulsórias através de taxações. Outro modo de transferir recursos de forma compulsória, segundo Meier, é quando o governo provoca termos de troca desfavoráveis à agricultura, controlando os preços agrícolas.

De forma genérica, Schuh (1989) coloca alguns papéis que a agricultura pode desempenhar. Um bom desempenho da agricultura pode estar associado a melhor distribuição de renda, à sustentabilidade do crescimento econômico, geração de recursos no saldo da balança comercial, geração de empregos, balanço energético e produção de alimentos. Em outro trabalho, Schuh (1997) lista como contribuições a geração de divisas; aumento e distribuição da renda real do consumidor quando há expansão da oferta e queda dos preços das "commodities" de consumo doméstico, além de que o benefício social será proporcionalmente maior quanto maior for a parcela da renda gasta com estes produtos.

\footnotetext{
${ }^{17}$ Op. cit.

${ }^{18}$ MYINT, H. Agriculture and economic development in the open economy. In: REYNOLD, L.G. (Ed.) Agriculture in development theory. New Haven: Yale University Press, 1975.
} 
Segundo Owen (1975), existem dois tipos de pressão sobre a agricultura, um de produção (requisição intersetorial de incrementos de produto) e outro de gastos (requisição de renda agrícola residual para finalidades não-agrícolas ou sociais). Yotopoulos \& Nugent (1976), destacam três aspectos dessa dupla pressão sobre a agricultura: 1) saída direta de capital, resultado do balanço líquido de compras e vendas do setor agrícola; 2) deterioração dos termos de troca domésticos; e, 3) transferência de capital humano via migração. Para estes últimos, o custo de criar e educar parte da oferta de trabalho não-agrícola representa uma transferência de capital.

Alguns autores tratam a relação entre necessidade de excedente agrícola e grau de abertura da economia. Segundo Little (1982), num sentido estrito, a necessidade de excedente agrícola é aplicável a economias fechadas, pois nas economias abertas os produtos agrícolas podem ser importados (desde que existam divisas). O autor ressalta que isto não implica que a agricultura deva ser negligenciada. Também Nicholls (1964) faz uma distinção entre os papéis da agricultura no desenvolvimento, dependendo do grau de abertura da economia. Para uma economia fechada, aumentos na produtividade da agricultura permitem que o setor libere mão-de-obra, tenha mais renda (e maior poder de compra de produtos não-agrícolas) e forneça alimentos a preços que permitam lucratividade à indústria. Para o autor, em economias abertas tal contribuição é menor, mas mesmo assim importante, na geração (e economia) de divisas para financiar importações. Conclui que, em ambos os casos, o crescimento da produtividade agrícola é essencial para o crescimento econômico. Obviamente, também o desenvolvimento dos setores industrial e de serviços cria condições favoráveis para a agricultura.

Johnston \& Mellor (1961) atribuem à agricultura os seguintes papéis: a) fornecer alimentos; b) fornecer capital, especialmente para a expansão do setor não-agrícola; c) fornecer mão-de-obra para o crescimento e diversificação de atividades na economia; d) gerar ganhos cambiais; e, e) constituir mercado para os produtos do setor não-agrícola. Estes papéis são freqüentemente encontrados em outros autores, como por exemplo 
Araújo \& Schuh (1995), Silva (1982), Stern (1994) e Kindleberger ${ }^{19}$, citado por Alves et al. (1996). É importante destacar, e isso nem sempre fica claro, que, para Johnston \& Mellor, tais papéis estão associados aos primeiros estágios do desenvolvimento econômico. ${ }^{20}$ Alguns deles, como o de suprimento de mão-de-obra, não se aplicam a estágios mais avançados do desenvolvimento de países onde a proporção de pessoas vivendo no setor rural é cada vez menor. Ainda segundo Martin (1976), é estranho falarse em contribuição de mão-de-obra no caso brasileiro. Não por culpa do setor agrícola, mas sim pelo tipo de política adotada e pelo viés urbano-industrial. Isto está de acordo com Staatz \& Eicher (1985) quando citam que, como a migração rural-urbana foi maior que o crescimento do emprego urbano, a preocupação dos "policy-makers" passou a ser tentar reduzir as "excessivas" taxas de urbanização.

Outros papéis, como constituir mercado para os produtos do setor não-agrícola, teriam que ser requalificados. Pode continuar sendo importante em termos de valor, mas a composição da cesta muda de bens de consumo para bens de investimento e ou de produção direta (insumos), questão também levantada por Martin (1976).

Considerando o setor rural como u m todo, também são atribuídos outros papéis. De acordo com Pisani ${ }^{21}$, citado por Silva (1999, p.27):

"o espaço rural não mais pode ser pensado apenas como um lugar produtor de mercadorias agrárias e ofertador de mão-de-obra. Além dele poder oferecer ar, água, turismo, lazer, bens de saúde, possibilitando uma gestão multipropósito do espaço rural, oferece a possibilidade de, no espaço local-regional, combinar postos de trabalho com pequenas e médias empresas".

Silva (1999) cita que o mundo rural brasileiro tem novas funções e "novos" tipos de ocupações, além das atividades agropecuárias e agroindustriais. Como exemplos temse turismo e lazer, moradia (condomínios rurais fechados) e fornecimento de empregos

\footnotetext{
${ }^{19}$ KINDLEBERGER, C.P. Desenvolvimento econômico. São Paulo: McGraw-Hill, 1996. 434p.

${ }^{20}$ Johnston \& Kilby (1977) também citam os mesmos tipos de papéis para a agricultura, sem destacar que sāo aplicáveis aos primeiros estágios do crescimento econômico. Stevens \& Jabara (1988) sāo outro exemplo de autores que se referem aos papéis clássicos da agricultura, sem especificar os estágios do desenvolvimento.

${ }^{21}$ PISANI et al. Que agricultura queremos para la Unión Europea? El Pais, Madrid, 17 Abril 1996.
} 
até então tipicamente urbanos (mecânicos, contadores, secretários). Isto está de acordo com Lewis (1995b), segundo o qual a solução para o desemprego nas cidades não está associada somente a investimentos urbanos, mas também a fazer as áreas rurais economicamente viáveis, com maior área cultivada, maior produtividade, mais indústrias rurais e mais facilidades sociais.

A ênfase sobre a importância da agricultura principalmente nos estágios iniciais do desenvolvimento de uma nação está associada, ou tem raiz, em outro fenômeno: a redução da participação da agricultura no produto e no emprego. Além disso, o reconhecimento de que o fato de reduzir tal participação não implica redução da importância do setor pode levar a mudança de ênfase quanto aos papéis da agricultura no desenvolvimento econômico. $O$ item seguinte apresenta uma revisão a respeito da participação da agricultura no produto e no emprego, de forma geral e no caso do Brasil em particular.

\subsection{Participação relativa da agricultura no produto e no emprego}

Vários autores comentam o declínio relativo da importância da agricultura ao longo do tempo (Johnston \& Mellor, 1961; Ohkawa \& Rosovsky, 1961; Fei \& Ranis, 1975; Yotopoulos \& Nugent, 1976; Stevens \& Jabara, 1988; Syrquin, 1988; Timmer, 1988; Stern, 1994). Chenery (1988) confirma que os deslocamentos de capital e trabalho da agricultura para outros setores ao longo do processo de desenvolvimento é fato amplamente citado na literatura.

Para Syrquin (1988) um dos tipos mais uniformes de mudança na demanda é o declínio da participação dos alimentos no consumo, ou seja, há um deslocamento da demanda para commodities industriais e serviços. Durante o processo de desenvolvimento, cresce o uso e a variedade dos bens intermediários, sendo que decresce o uso relativo de bens intermediários primários enquanto cresce o de intermediários da indústria pesada e dos serviços. As mudanças técnicas na agricultura e 
ou aumento no preço relativo do trabalho induzem a mecanização e o uso de insumos (combustíveis, fertilizantes, bens de capital), o que faz com que o valor adicionado do setor diminua. Um estudo para 97 países no período 1950-83 teve como resultado marcante generalizada associação inversa entre renda e participação da agricultura na renda e no emprego.

Segundo Stern (1994), a tendência de queda de participação no produto e na renda pode ser entendida como "ao longo dos estágios de crescimento". Sabe-se que uma das características da economia brasileira (e de sua agricultura em particular) é a desigualdade regional. Assim, aquelas regiões que estão em "estágios" mais atrasados têm em um possível excedente financeiro agrícola importante fonte de recursos para desenvolvimento. ${ }^{22} \mathrm{O}$ mesmo autor, analisando dados de vários países, verificou associação positiva entre crescimento agrícola e não-agrícola no período 1965-1980, relação esta que desapareceu na década de 1980. Isto pode ser verificado na Tabela 1. Para Stern, a agricultura é vista como possibilitadora e facilitadora do crescimento, e não como seu motor. O autor observa, no entanto, que a queda de participação no produto pode ser resultado de mudanças nos preços relativos e, além disso, para o fato de que a inexistência de relação na década de 1980 pode estar associada aos vários choques em muitos países, o que desacelerou dramaticamente o crescimento, principalmente o industrial.

Note-se que não existe consenso a respeito da questão de quem é o "motor" do crescimento: como pode a indústria ser tal motor, parar de crescer, e a agricultura continuar crescendo como ocorreu na economia brasileira na década de 80 ? Ishikawa (1967b) enfatiza que a mudança de saída para entrada de recursos na agricultura da China ocorreu em resposta à expansão do desenvolvimento econômico. Porém, existem autores que afirmam o contrário. Timmer (1988) chama a atenção para a existência de dois aspectos relacionados a agricultura e desenvolvimento econômico. O primeiro é a

\footnotetext{
${ }^{22}$ É claro que não podem ser descartadas as transferências interregionais, tanto diretas como por meio de
} agências governamentais. 
queda da participação no PNB e na força de trabalho. O outro é de que um rápido crescimento da agricultura preceda ou acompanhe o crescimento econômico geral.

Tabela 1. Alocações setoriais de produção em 1965, 1980 e 1990 e de trabalho em 1965 e 1980.

\begin{tabular}{|c|c|c|c|c|c|c|c|}
\hline \multirow{3}{*}{ País } & \multirow{3}{*}{$\begin{array}{l}\text { PNB per } \\
\text { capita } \\
\text { em } 1990\end{array}$} & \multicolumn{6}{|c|}{ Fração do produto $(\%)$} \\
\hline & & \multicolumn{2}{|c|}{ Agricultura } & \multicolumn{2}{|c|}{ Indústria } & \multicolumn{2}{|c|}{ Serviços } \\
\hline & & $65 \quad 80$ & 90 & 6580 & 90 & 6580 & 90 \\
\hline Brasil & 2680 & $19 \quad 10$ & 10 & $33 \quad 37$ & 39 & $48 \quad 53$ & 51 \\
\hline Economias de baixa renda & 350 & 36 & 31 & 26 & 36 & 32 & 35 \\
\hline $\begin{array}{l}\text { Economias de baixa renda, excluindo } \\
\text { China e Índia }\end{array}$ & 320 & 42 & 30 & 20 & 34 & 38 & 38 \\
\hline Economias de renda média-baixa & 1530 & 22 & 17 & 32 & 31 & 44 & 50 \\
\hline Economias de renda média-alta & 3410 & 16 & 9 & 36 & 40 & 47 & 51 \\
\hline $\begin{array}{l}\text { Economias de renda média e baixa, por } \\
\text { região }\end{array}$ & 840 & 29 & 17 & 30 & 37 & 40 & 47 \\
\hline África Sub-Sahariana & 340 & 40 & 32 & 20 & 30 & 39 & 40 \\
\hline Leste da Ásia e Pacífico & 600 & 37 & 21 & 32 & 45 & 30 & 36 \\
\hline Sul da Ásia & 330 & 44 & 33 & 21 & 26 & 35 & 41 \\
\hline Meio Leste e Norte da África & 1790 & 20 & & 38 & & 40 & \\
\hline América Latina e Caribe & 2180 & 16 & & 33 & 36 & 50 & 54 \\
\hline \multirow{3}{*}{ País } & \multirow{3}{*}{$\begin{array}{l}\text { PNB per } \\
\text { capita } \\
\text { em } 1990-\end{array}$} & \multicolumn{6}{|c|}{ Fraçāo do emprego (\%) } \\
\hline & & \multicolumn{2}{|c|}{ Agricultura } & \multicolumn{2}{|c|}{ Indústria } & \multicolumn{2}{|c|}{ Serviços } \\
\hline & & 65 & 80 & 65 & 80 & 65 & 80 \\
\hline Brasil & 2680 & 49 & 31 & 20 & 27 & 31 & 42 \\
\hline Economias de baixa renda & 350 & 77 & 72 & 9 & 13 & 14 & 15 \\
\hline $\begin{array}{l}\text { Economias de baixa renda, excluindo } \\
\text { China e Índia }\end{array}$ & 320 & 79 & 71 & 8 & 10 & 13 & 19 \\
\hline Economias de renda média-baixa & 1530 & 65 & 55 & 12 & 16 & 23 & 29 \\
\hline Economias de renda média-alta & 3410 & 45 & 29 & 23 & 31 & 32 & 40 \\
\hline
\end{tabular}

Fonte: adaptado de Stern (1994).

Chenery (1988) ressalta que a mudança do centro de gravidade da economia da produção primária para a manufatura e os serviços está relacionada a outras mudanças 
estruturais como migração, urbanização e deslocamento das vantagens comparativas. Fei \& Ranis (1975), também citam que o deslocamento do centro de gravidade da economia da agricultura em direção à indústria ocorre através da redistribuição de fatores.

Brandão \& Alves (1993) também confirmam a tendência à queda da participação da agricultura na renda e no emprego no Brasil, como pode ser verificado na Tabela 2 , que mostra a participação do setor na renda, nas exportações, no emprego e taxas de crescimento de 1950 a 1987.

Tabela 2. Características estruturais da agricultura brasileira (em \%).

\begin{tabular}{ccccc}
\hline Períodos & $\begin{array}{c}\text { Participação } \\
\text { na renda }\end{array}$ & $\begin{array}{c}\text { Participação no } \\
\text { emprego }\end{array}$ & $\begin{array}{c}\text { Participação no total } \\
\text { das exportações }\end{array}$ & $\begin{array}{c}\text { Taxa de crescimento } \\
\text { média do produto real }\end{array}$ \\
\hline $50-59$ & 19 & 61 & 94 & 4,4 \\
$60-69$ & 16 & 55 & 84 & 3,8 \\
$70-79$ & 11 & 44 & 61 & 4,0 \\
$80-87$ & 11 & 30 & 41 & 3,2 \\
\hline
\end{tabular}

Fonte: Brandão \& Alves (1993).

Existem diferentes considerações a respeito da importância relativa da agricultura quando se caminha para estágios mais avançados do desenvolvimento. As primeiras reflexões sobre o papel da agricultura, conforme já destacado, eram de que este setor serviria somente como fonte de recursos para o resto da economia. Por exemplo, para Fei \& Ranis (1975, p.135), "parece haver pouca dúvida sobre a importância geral da proximidade da indústria para a elevação da produtividade agrícola nos EUA”. Esses autores, diferentemente do que ocorre com a ressalva feita por Lewis ${ }^{23}$, dizem que o setor industrial constitui a porção dinâmica da economia. A proposição de que a grande importância da agricultura se dá nos primeiros estágios do desenvolvimento, apesar de amplamente aceita, pode ser questionável. Isto porque existem autores que reforçam que a agricultura, mesmo com o processo de desenvolvimento, continua a desempenhar importante papel na economia. Schuh (1997) acredita ser enganoso o argumento de que

\footnotetext{
${ }^{23}$ Op. cit. Isto porque no dualismo de Lewis a distinção é entre um setor tradicional e outro dinâmico, e não entre agrícola e não-agrícola.
} 
uma vez que há queda da participação da agricultura no PIB e no emprego, os recursos devem ser alocados preferencialmente nos outros setores. $O$ autor afirma que a agricultura pode contribuir para o desenvolvimento da economia como um todo mesmo nos estágios mais avançados. Timmer (1988) aponta que a associação entre a queda da participação da renda e no emprego leva a uma percepção errada de que a agricultura não é importante. Para Staatz \& Eicher (1985), artigos como o de Johnston \& Mellor (1961) e o de Nicholls (1964) foram importantes tanto para reconhecer o papel positivo da agricultura do desenvolvimento econômico, como para estimular o debate sobre a interdependência entre o crescimento agrícola e o industrial. ${ }^{24}$

Stevens \& Jabara (1988) citam que, apesar da queda da participação dos alimentos nos gastos totais com o aumento da renda, os gastos com alimentos, em termos absolutos, crescem fortemente. Importante é destacar que essa função ligada à alimentação, para Schuh (1997), pouco tem a ver com o significado da agricultura para o PIB ou sua participação no emprego. Tem importância, sim, na competitividade da economia pelo fato dos alimentos serem bens salário. Para o autor, o aumento e a distribuição na renda levam ao aumento da demanda por bens e serviços de outros setores. Também para Lewis (1995b), se a agricultura não se desenvolve, pode afetar a distribuição de renda, o inchaço das cidades, o balanço de pagamentos e o desenvolvimento industrial (pois a população agrícola não tem poder de $\operatorname{compra}^{25}$ ). Isto está de acordo com Goldin \& Rezende (1993), segundo os quais a indústria foi a força motriz do desenvolvimento em muitos países no período 1965-1980, mas depois de 1980 a agricultura continuou crescendo enquanto o crescimento industrial foi freado. Neste sentido, estes autores afirmam que a agricultura exerceu uma força estabilizadora e amorteceu o colapso de crescimento da renda. Tal comportamento pode ser visualizado na Tabela 3.

\footnotetext{
${ }^{24}$ Nas referências mais antigas não era dada ênfase aos serviços.

${ }^{25}$ Se bem que, como visto anteriormente, este último merece algumas ressalvas.
} 
Tabela 3. Taxas médias anuais de crescimento dos diferentes setores nos países subdesenvolvidos, de 1965 a 1988 (em \%).

\begin{tabular}{ccccccc}
\hline Grupo de países & \multicolumn{2}{c}{ PIB } & \multicolumn{2}{c}{ Indústria } & \multicolumn{2}{c}{ Agricultura } \\
& $1965-80$ & $1980-88$ & $1965-80$ & $1980-88$ & $1965-80$ & $1980-88$ \\
\hline Países de baixa renda (exc. & 5,5 & 2,0 & 10,0 & 1,7 & 2,3 & 2,3 \\
China e Índia) & & & & & & \\
Economias de renda média & 6,1 & 2,9 & 5,9 & 3,2 & 3,2 & 2,7 \\
América Latina & 6,0 & 1,5 & 6,0 & 1,1 & 3,3 & 2,5 \\
África Sub-Sahariana & 4,8 & 0,8 & 9,4 & $-0,8$ & 1,3 & 1,8 \\
Sul Asiático & 3,7 & 5,1 & 4,4 & 7,3 & 2,5 & 2,5 \\
Leste Asiático (incl. & 7,2 & 8,5 & 10,8 & 10,3 & 3,2 & 5,7 \\
Brasil & 8,8 & 2,9 & 10,1 & 2,6 & 3,8 & $3,5 *$ \\
\hline
\end{tabular}

Fonte: Goldin \& Rezende (1993).

* notável em relação à contração muito mais forte sofrida pela indústria.

Para Oliveira (1984) os resultados de seu estudo sugerem uma refutação à idéia de que a agricultura só é importante nos estágios iniciais do desenvolvimento. Segundo o autor:

"a experiência brasileira do pós-guerra mostrou que, mesmo em um estágio mais avançado do desenvolvimento industrial, quando o setor agrícola é relativamente pequeno, a agricultura pode contribuir com uma grande proporção de recursos requeridos para sustentar a taxa de investimento" (Oliveira, 1984, p.819).

A despeito das considerações anteriores, Teubal (1971) afirma que uma análise dos fatores que contribuem para a geração, apropriação e uso do excedente agrícola pode ser interessante para entender as interconexões entre a agricultura e a economia como um todo, não somente nos estágios iniciais. Essas afirmações tornam-se particularmente relevantes quando se pensa na questão das desigualdades regionais. A produção agrícola nas diferentes regiões de um país pode estar associada a diferentes estágios do processo de desenvolvimento regional e, além disso, uma vez atingidos estágios mais avançados, o setor agrícola precisa continuar "superavitário". Isto também pode ser apreendido daquilo que Timmer (1988) chama de fases da transformação agrícola: 1) aumento da produtividade do trabalho e geração de excedente; 2) transferência do excedente para o 
setor não-agrícola, diretamente, via taxação ou fluxos de fatores, ou indiretamente, via intervenção do governo nos termos de troca; 3) progressiva integração dos setores agrícola e não-agrícola nos mercados de fatores e produtos; e, 4) a agricultura passa a ter um papel semelhante ao dos demais setores.

Estudiosos da história econômica concordam que o desenvolvimento no longo prazo não é viável se estiver baseado somente em um setor. As relações entre os setores agrícola e não-agrícola fazem com que ambos, e as complexas relações que têm entre si, devam ser levadas em conta (Eicher \& Witt, 1964). De acordo com Bacha (1995) a modernização da agricultura requer altos investimentos iniciais, logo é difícil predizer a direção dos fluxos de capital entre agricultura e indústria. Esses setores não podem ser tratados separadamente se a preocupação é com o bem-estar da nação como um todo, e não somente de alguns grupos sociais específicos.

Lewis (1995a) comenta sobre a rápida industrialização da Índia Ocidental. Segundo ele, para que houvesse possibilidade de nível de vida decente, seria necessário que boa parte (metade) da população rural migrasse para permitir avanços tecnológicos, em razão da pequena disponibilidade de terras em relação à população. Para tanto, seria necessário criar empregos não-agrícolas. Ou s eja, não se pode, em situações como esta, falar em priorizar o desenvolvimento de um ou outro setor. Então é possível verificar a complementaridade intersetorial.

A noção de interdependência é importante no presente estudo. É que se pretende analisar o setor agrícola não de forma isolada, mas como parte de um todo com o qual interage. O excedente que se pretende estudar é o resultado de transações entre setores que têm influência mútua. 


\subsection{Retrospectiva das políticas agrícolas no Pós-Guerra}

Esta seção tem por objetivo apresentar alguns aspectos da história recente das políticas agrícolas no Brasil. O principal motivo é chamar a atenção para o fato de que tais políticas, de forma geral, não tiveram relação com eventuais desempenhos positivos do setor agrícola, seja pelo seu caráter indefinido, circunstancial ou mesmo discriminatório. Some-se a isso o fato de a agricultura ser mais sensível às políticas macroeconômicas em geral do que às políticas específicas do setor.

Alguns trabalhos tratam da conexão entre política e o desenvolvimento dos setores agrícola e não-agrícola. De acordo com o Banco Mundial2 ${ }^{26}$, citado por Timmer (1988, p.277):

"a contínua importância da agricultura nas economias dos países em desenvolvimento se reflete na associação entre o crescimento da agricultura e o da economia em geral.... Os paralelos entre os crescimentos da agricultura e do PNB sugerem que os fatores que afetam o desempenho agrícola podem estar ligados a políticas sociais e econômicas para a economia como u m todo".

Schuh (1997) faz um resumo das políticas que influenciaram a agricultura brasileira nas últimas cinco décadas. $O$ autor comenta que, durante os anos 50 e boa parte dos anos 60, a política de industrialização negligenciou a agricultura em termos de investimentos e discriminou a mesma, principalmente via sobrevalorização da moeda brasileira, provocando um imposto sobre as exportações. Ocorreram também confiscos e imposição de impostos explícitos para garantir a oferta doméstica. ${ }^{27}$ Esse panorama foi alterado no período 1964-1973 com a tentativa de reinserir o Brasil na economia mundial. "A taxa cambial foi mudada para um nível mais realista, as tarifas e outras proteções do setor manufatureiro reduzidas e as condições domésticas de comércio foram alteradas em favor do setor agrícola" (Schuh, 1997, p.17).

\footnotetext{
${ }^{26}$ WORLD BANK. World development report, 1982. New York: Oxford University Press, 1982.

${ }^{27}$ Ver também Schuh (1989). Schuh (1971) relata que a exportação de produtos alimentícios foi proibida por algum tempo no Pós-Guerra, como forma de manter o custo de vida da população urbana em níveis baixos.
} 
Nas décadas de 50 e 60, as políticas agrícolas foram direcionadas principalmente para resolver crises imediatas de produção que implicassem aumento do custo de vida urbano. No entanto, é necessário dizer que os agricultores se beneficiaram, por algum tempo, de taxas de câmbio favoráveis para a aquisição de fertilizantes, produtos derivados de petróleo, tratores e caminhões. Pode-se destacar também a construção de armazéns, de estradas, subsídio ao uso de insumos modernos, isenção de impostos e crédito subsidiado (Schuh, 1971; Nicholls, 1975). Note-se que mesmo estes benefícios tinham como objetivo primário o favorecimento do setor industrial.

No início da década de 1970 houve os choques do petróleo, o início do investimento em pesquisa agrícola e capacitação pessoal, além da expansão do crédito subsidiado. A crise dos anos 80 mostrou-se favorável à agricultura uma vez que novamente a "proteção teve que ser reduzida, a taxa cambial mais realista, os impostos sobre as exportações eliminados e as exportações estimuladas" (Schuh, 1997, p.18). Na década de 90 voltou a se verificar discriminação contra o setor agrícola, principalmente via sobrevalorização da moeda e as altas taxas de juros reais. Gasques \& Villa Verde (1991) citam que a política de estabilização via controle monetário e fiscal, adotada a partir de março de 1990, provocou redução de recursos para a agricultura (tanto os provenientes do setor público quanto do privado), o que compromete seu fortalecimento no médio prazo.

Delgado (1989), também fazendo retrospectiva da agricultura brasileira de 1947 a 1988, cita que o lugar da mesma no processo de desenvolvimento segue as transformações do conjunto da economia. O autor confirma a existência, no período 1947-1961, de mecanismos cambiais e comerciais para transferir excedentes econômicos da agricultura para a economia urbana e industrial. Também neste sentido, Goldin \& Rezende (1993) citam mecanismos de transferência compulsória utilizados neste período: tributação via taxa de câmbio supervalorizada para financiar o desenvolvimento da indústria de transformação; controle de preços de produtos alimentícios domésticos e proibição de exportações agrícolas pressionando reduções nos seus preços para que se tivesse alimentos mais baratos para a força de trabalho industrial. Essas transferências se 
reduziram após 1964 com mudanças na política cambial e crescente liberalização do comércio exterior.

A partir de 1964 verificam-se novas demandas e estratégias produtivas, destacando-se: "a) o crescimento e diversificação das exportações; b) aceleração do crescimento urbano e suas projeções em termos de demanda agrícola; c) mudança na base técnica de produção rural; d) constituição dos complexos agro-industriais com crescentes nexos da integração técnica agricultura-indústria; e, e) constituição do Sistema Nacional de Crédito Rural e adoção de política de financiamento subsidiado à produção no interior desses complexos" (Delgado, 1989, p.125). A crise dos anos 80 e a redução dos subsídios e incentivos financeiros não teve tanta repercussão na agricultura quanto no resto da economia (ver Tabela 3).

Os dois primeiros Capítulos desta pesquisa permitem que se tenha noção da complexidade que envolve a questão da contribuição do setor agrícola: a importância do setor para a economia, a diversidade de experiências ao redor do mundo e em diferentes épocas, a interdependência com outros setores e a influência das políticas públicas. No Capítulo seguinte são apresentadas as diferentes maneiras pelas quais outros autores abordaram o assunto, especificamente quanto à forma de mensuração do resultado das transferências de recursos entre os setores agrícola e não-agrícola. 


\section{MÉTODOS DE ESTIMAÇÃO DO EXCEDENTE AGRÍCOLA}

Aspecto importante da maneira pela qual diferentes autores mensuraram 0 excedente do setor agrícola é a variedade de definições. Isto faz com que os exemplos citados no Capítulo 1 não sejam diretamente comparáveis entre si. Este Capítulo tem por objetivo mostrar, de forma explícita, tal diversidade e, de certa forma, a evolução que ocorreu no tratamento do assunto. São apresentadas inicialmente definições gerais dadas por alguns autores, seguidas por exemplos de métodos, propriamente ditos, utilizados na estimação do excedente agrícola.

De acordo com Teixeira (1994), os instrumentos usados no Brasil para transferir renda da agricultura foram "a sobrevalorização cambial, as restrições às exportações, as tarifas elevadas à importação de insumos e máquinas, os impostos indiretos, as importações subsidiadas de produtos agrícolas, os confiscos, os tabelamentos, os congelamentos e as correções diferenciadas para a dívida agrícola e para os preços mínimos" (Teixeira, 1994, p.41). As compensações ocorreram, principalmente via crédito subsidiado, mas foram muito concentradas. Segundo o autor, o empobrecimento relativo da agricultura teve início na década de 50, com as políticas de substituição de importações e continua "até hoje" (data da publicação) com os planos de estabilização econômica.

Para Oliveira (1984), as distorções de preços nos mercados de produto e insumos pós 1960 são relevantes na explicação das transferências intersetoriais de renda, pois constituem mecanismo altamente seletivo de taxação agrícola e transferência de renda entre setores no Brasil, removendo recursos dos grupos mais pobres e menos capitalizados para grupos capitalistas tanto urbanos quanto rurais. A compensação das 
taxações com os subsídios também foi um elemento concentrador de renda no setor agrícola, pois os pequenos/pobres eram taxados, mas não tinham acesso ao subsídio de insumo e/ou de crédito. As transferências diretas, via fluxos de poupança líquida voluntária e taxação direta líquida, não foram relevantes no pós-guerra (pelo menos até 1974). A maior significância foi das transferências por meio da taxação implícita.

De acordo com Mellor (1985), a direção dos fluxos pode depender da relação, entre os valores nos diferentes setores, de um complexo de fatores que inclui taxas de retorno do capital, razão capital/produto, taxas de poupança e demanda por produtos agrícolas. Esses fatores, por sua vez, são influenciados pela mudança tecnológica na agricultura (e também nos outros setores).

O primeiro ponto interessante para o qual Kuznets (1964) chama a atenção quanto à mensuração do excedente é a interdependência entre os diferentes aspectos do crescimento econômico. Este autor destaca, por exemplo, o aspecto estrutural — as mudanças na importância relativa das diferentes indústrias e regiões, formas de organização, participação das "commodities" no produto final etc. e o aspecto internacional - o crescimento de uma nação ocorre dentro de um ambiente de relações internacionais. Tal interdependência, de certa forma, dificulta o isolamento da contribuição de um setor específico para cada um dos aspectos.

Outro ponto, também relativo à interdependência, só que entre os setores da economia (destacada no Capítulo anterior), dificulta a mensuração de contribuições "individuais". O resultado de um setor depende de suas relações com os outros, e mesmo com o exterior. O setor não pode ser visto como desligado do resto da economia (Kuznets, 1964). Ishikawa (1967a), citado por Evangelista (1997), comenta a respeito da sobreposição que existe entre a agricultura e os outros setores, por exemplo, a renda de atividades não-agrícolas que entra no setor agrícola e que complica o isolamento da contribuição de um setor. Também Millar (1970) comenta que, mesmo com várias maneiras de se dividir a economia, a interdependência entre os setores é um forte obstáculo à atribuição de um excedente a determinado setor. 
Evangelista (1997) apresenta diferentes formas de mensuração do excedente financeiro agrícola, utilizadas por Teubal (1971), Ishikawa (1967a), Morrison \& Thorbecke (1990) e Karshenas (1994). A estrutura deste Capítulo foi pensada a partir de Evangelista (1997), procurando incorporar trabalhos por ele citados e outros encontrados na literatura.

\subsection{Ohkawa \& Rosovsky (1961)}

Ohkawa \& Rosovsky (1961) fazem interessante análise sobre a poupança agrícola, maior que os investimentos no setor e canalizada para o setor não-agrícola. Ou seja, para esses autores, esta diferença entre poupança e investimentos no setor corresponde aos recursos disponibilizados. ${ }^{28}$ Essa noção é semelhante à de Teubal (1971, 1975), Colomé (1978) e Gutierrez \& Barbero (1988).

Ohkawa \& Rosovsky citam que existem 2 importantes problemas nas relações ruralurbano envolvidas no papel da agricultura no desenvolvimento econômico:

a) movimento da força de trabalho e fontes de capacidade empresarial para as cidades; e,

b) fluxos de investimento das regiões rurais para as urbanas.

Estudaram a questão dos fluxos de investimento das regiões rurais para as urbanas. Fizeram isso analisando basicamente os pagamentos de impostos pelo setor agrícola e os gastos do governo. Encontraram dificuldades de mensuração, que teve que ser indireta, devido à não adequação e/ou disponibilidade de dados. Quanto aos impostos sobre a terra (land tax) incidentes na agricultura, mostram que durante fase expressiva do desenvolvimento econômico japonês (de 1888 a 1917) eles constituíram a fonte de receita mais importante para o governo. Em relação aos gastos do governo no setor

\footnotetext{
${ }^{28}$ Em Mundle \& Ohkawa (1979) também aparece esse tipo de comparação entre poupança e investimento na agricultura, mostrando que houve uma pesada drenagem de recursos para fora da agricultura do Japão, uma vez que a poupança foi maior que o investimento.
} 
agrícola, os autores analisaram subsídios, que passaram a ser importantes a partir da década de 1930. Com isso, concluem (e admitem que o fazem de forma altamente conjetural), que nos primeiros estágios do desenvolvimento havia fluxo de capital das áreas rurais para as urbanas, e que tal fluxo tenha sofrido reversão após a Primeira Guerra Mundial.

\subsection{Ishikawa (1967a)}

Para este autor, a questão real repousa na possibilidade de transferência de recursos do setor tradicional para financiar o crescimento de um setor moderno emergente (visão tipicamente dualista, tal qual aparece em Lewis ${ }^{29}$ ). Portanto, trabalha com o conceito de "farm sector" (setor fazendas), que inclui todas as atividades econômicas das famílias agrícolas.

Ainda segundo o autor, os recursos correspondem a fundos para financiar o desenvolvimento econômico, ou seja, compreendem transferências de poupanças e outros fluxos financeiros originados de serviços de fatores e transferências correntes. Quando o governo realiza investimentos públicos ou outras atividades que afetam diretamente as atividades do setor fazendas, tais gastos do governo são considerados doações, e tratados como entrada de recursos no setor.

O fluxo de recursos é medido pelo valor real das exportações e importações de commodities do setor fazendas e seu balanço líquido, ou seja,

$M / P_{m}-E / P_{e}=R / P_{m}+E\left[\left(P_{e} / P_{m}\right)-I\right] / P_{e}$

Onde:

$R=M-E$ : excesso de importações

$\mathrm{M}=$ valor das importações;

${ }^{29}$ Op. cit. 
$\mathrm{E}=$ valor das exportações;

$\mathrm{P}_{\mathrm{m}}=$ índice de preços de importação; e,

$\mathrm{P}_{\mathrm{e}}=$ índice de preços de exportação.

O lado direito de (3.2.1) mostra que o fluxo de recursos consiste de duas partes: uma visível $\left(\mathrm{R} / \mathrm{P}_{\mathrm{m}}\right)$ e outra invisível, isto é, através de mudanças nos termos de troca internos $\left(E\left[\left(\mathrm{P}_{\mathrm{e}} / \mathrm{P}_{\mathrm{m}}\right)-1\right] / \mathrm{P}_{\mathrm{e}}\right)$. $\mathrm{O}$ valor corrente do balanço líquido de comércio de commodities $(\mathrm{R})$ precisa ser idêntico à soma dos recebimentos de desembolsos dos serviços de fatores e transferências correntes (V) e as transferências líquidas de capital e empréstimos líquidos (K):

$V+K=R$

O autor apresenta também outras medidas/conceitos parciais de transferência líquida de recursos:

- E: venda de produtos agrícolas e pagamentos de impostos e outras dívidas em espécie;

- M: compra de bens de consumo e serviços, bens/insumos intermediários e bens de investimento para formação de capital fixo; e, valor de bens e serviços envolvidos nos gastos correntes e de capital do governo no setor fazendas;

- V: do lado das entradas tem-se o recebimento líquido de salários pelos membros da famílias, renda líquida de atividades complementares, recebimentos de transferências privadas, gastos correntes do governo no setor fazendas e subsídios em conta corrente. Do lado das saídas tem-se o pagamento líquido de aluguéis e juros e o pagamento de impostos e dívidas; e,

- K: do lado das entradas tem-se os empréstimos de dinheiro, gastos de capital pelo governo e subsídios em conta corrente ao setor fazendas. Do lado das saídas tem-se poupanças financeiras e pagamento de empréstimos. 
Para Ishikawa, os índices de preços pagos e recebidos pelos fazendeiros são conceitualmente os mais apropriados para representar $P_{e}$ e $P_{m}$ na equação (3.2.1), embora não explique porquê. Relata também dificuldade de escolher o ano base do índice de preços para calcular o valor real dos fluxos. O ideal seria escolher um ano sem a ocorrência de transferências invisíveis, ou seja, em que tenha havido um equilíbrio geral nos mercados de produtos e fatores. Como a detecção de tal ano é muito difícil, o valor e a direção do fluxo passam a ser relativos, pois dependem da escolha arbitrária de um ano base. Em outro artigo, afirma que não se pode tomar qualquer ano como base para os cálculos dos valores reais dos fluxos (Ishikawa, 1967b). Neste caso escolheu, por exemplo, um ano que parecia ter menor influência de controle sobre os mercados, ou seja, em que o mercado teria funcionado em condição relativamente normal. Ainda segundo este autor, diferentes índices podem provocar deslocamentos verticais da curva de resultados como um todo, embora as tendências não sejam alteradas (Ishikawa, 1967b).

\subsection{Millar (1970)}

Ponto interessante levantado por Millar (1970) é que o excedente está associado a algo que está acima de algum uso ou necessidade especificado. Então, a definição de um excedente econômico estará necessariamente ligada a algum nível de uso ou necessidade para manter determinada condição econômica. Desta forma, quando o setor agrícola apresenta geração de recursos maior que suas próprias necessidades, é capaz de liberar recursos dentro de um ambiente de interação com o resto da economia.

Para analisar a importância do excedente agrícola para o processo de industrialização, Millar (1970) considera uma economia com dois setores. O primeiro produz somente produtos agrícolas, no máximo semi-processados. O setor não-agrícola compreende todas as atividades de produção não-agrícola, como manufaturas, transporte, comunicação e serviços. O autor identifica os fluxos de produtos entre os setores por origem (primeiro subscrito) e destino (segundo subscrito) e tipo de uso: 
consumo (C) e investimento (I). O subscrito 1 indica setor agrícola e o 2 setor nãoagrícola. As definições usadas por Millar são baseadas no sistema de contabilidade setorial como segue.

Seja A o produto bruto de um setor. Então, o do setor agrícola e sua distribuição é definido como:

$A_{1}=C_{I 1}+C_{12}+I_{11}+I_{12}$

De forma análoga, o produto do setor não-agrícola é:

$A_{2}=C_{22}+C_{21}+I_{21}+I_{22}$

O excedente não consumido do setor agrícola $\left(U_{1}\right)$ é definido como o volume corrente do produto bruto que não é consumido, usado na produção corrente ou "destruído" de outra forma no próprio setor. ${ }^{30}$ Também pode ser visto como a porção do produto bruto corrente que é comercializada e/ou remetida ao setor não-agrícola somada àquela retida no setor agrícola, mas não utilizada para consumo:

$U_{l}=A_{1}-C_{11}$

ou

$U_{I}=C_{12}+I_{12}+I_{11}$

O excedente comercial do setor $\left(\mathrm{M}_{1}\right)$ corresponde ao volume de bens e serviços fornecidos em transações intersetoriais:

$M_{1}=C_{12}+I_{12}$

ou

$M_{I}=U_{l}-I_{I I}$

${ }^{30}$ Corresponde ao excedente agrícola definido por Nicholls (1975). 
Este excedente comercial só representa os gastos líquidos em investimento atual (ou potencial) na suposição de as aquisições provenientes do setor não-agrícola serem nulas. Por isso, o autor define o excedente líquido do setor agrícola $\left(\mathrm{N}_{1}\right)$. Dada uma apropriada ponderação de preços, o $N_{1}$ mede a contribuição líquida do setor para o investimento líquido na economia como um todo:

$N_{I}=U_{I}-C_{21}$

O excedente líquido é uma estimativa do investimento líquido por setor de origem. Isso pode ser visto através da consolidação das contas para os dois setores, que mostra o investimento líquido agregado:

$$
\begin{aligned}
N_{1}+N_{2} & =\left(U_{1}-C_{21}\right)+\left(U_{2}-C_{12}\right) \\
& =\left(C_{12}+I_{12}+I_{11}-C_{21}\right)+\left(C_{21}+I_{2 I}+I_{22}-C_{12}\right) \\
& =I_{11}+I_{12}+I_{21}+I_{22}
\end{aligned}
$$

Segundo o autor, o excedente líquido é um conceito apropriado a qualquer modelo que assuma interdependência entre os setores da economia. Dado um sistema de preços relativos e um valor de investimento agregado líquido, quanto maior o excedente líquido de um setor, maior a contribuição desse setor para o investimento líquido agregado. De modo similar, para dado produto bruto, quanto menores as aquisições nas contas corrente e de capital, maior será a contribuição líquida para os outros setores.

\section{$3.4 \quad$ Teubal $(\mathbf{1 9 7 5})^{31}$}

Segundo Teubal (1975), no contexto de uma economia onde os trabalhadores rurais e camponeses são parte substancial da PEA e onde a agricultura gera uma proporção significativa do Produto Nacional, pode ser aplicado o conceito de excedente

\footnotetext{
${ }^{31}$ Semelhante ao que é apresentado em Teubal (1971).
} 
agropecuário (EA) como a parte da produção agrícola que se comercializa ou é transferida para as cidades para alimentar a população urbana. Neste caso:

$E A=Y_{a}-C_{a}{ }^{a}$,

Onde

$\mathrm{Y}_{\mathrm{a}}$ : produto, valor agregado ou renda do setor agrícola; e,

$\mathrm{C}_{\mathrm{a}}^{\mathrm{a}}$ : consumo de bens agrícola s pelo próprio setor.

Este conceito é importante para tais economias pois o termo $\mathrm{C}_{\mathrm{a}}{ }^{\mathrm{a}}$ é significativo. Em economias onde quase a totalidade da produção agropecuária é comercializada no mercado, sendo relativamente marginal aquela de subsistência ou tradicional, o conceito representado por (3.4.1) corresponde aproximadamente ao conjunto de bens transferidos ao setor não-agrícola como matérias-primas, bens de consumo e exportações:

$E A \cong R_{a}^{n}+C_{a}^{n}+X_{a}$

Onde:

$\mathrm{R}_{\mathrm{a}}{ }^{\mathrm{n}}$ : matérias primas destinadas ao setor não-agrícola;

$\mathrm{C}_{\mathrm{a}}{ }^{\mathrm{n}}$ : bens de origem agropecuária consumidos pelo setor não-agrícola; e,

$\mathrm{X}_{\mathrm{a}}$ : exportações de origem agrícola.

Nos modelos tipo Ranis \& $\mathrm{Fei}^{32}$, a poupança agropecuária $\left(\mathrm{S}_{\mathrm{a}}\right)$ representa a parte do EA utilizável para investimento:

$S_{a}=E A-C_{n}{ }^{a}=Y_{a}-C^{a}$

Sendo,

${ }^{32}$ Op. cit. e RANIS, G.; FEI, J.C.H. Development of a labor surplus economy. Yale, 1964. 
$\mathrm{C}^{\mathrm{a}}$ : consumo do setor agrícola, $\mathrm{C}_{\mathrm{a}}=\mathrm{C}_{\mathrm{a}}{ }^{\mathrm{a}}+\mathrm{C}_{\mathrm{n}}{ }^{\mathrm{a}} ; \mathrm{e}$,

$\mathrm{C}_{\mathrm{n}}{ }^{\mathrm{a}}$ : bens de origem não-agrícola consumidos pelo setor agrícola.

É possível então definir o excedente financeiro do setor agrícola (EFa), seguindo os trabalhos empíricos de Ishikawa (1967a), Lee ${ }^{33}$ e da Economic Comission for Asia and the Far East (ECAFE) ${ }^{34}$, como:

$E F_{a}=S_{a}-I_{n a}$

Onde $I_{\text {na }}$ constitui os investimentos realizados no setor agrícola que consistem na aquisição de bens cuja origem é o setor não-agrícola, basicamente máquinas, equipamentos, implementos para melhorias e construções.

Tal conceito indica a disponibilidade de excedentes já realizados no setor, uma vez incorporados os correspondentes bens de investimento utilizados pelo mesmo. É financeiro no sentido que reflete a disponibilidade de fundos que podem ser transferidos a outros setores da economia ou ao exterior. Veja que é uma medida aparentemente restrita de excedente.

\subsection{Yotopoulos \& Nugent (1976)}

Yotopoulos \& Nugent (1976) usaram a seguinte seqüência para analisar os papéis da agricultura e da indústria no crescimento econômico através das interações entre os setores:

1) análise do excedente agrícola que pode ser transferido - e usado no setor nãoagrícola - via fluxo de trabalho, taxação sobre a agricultura e termos de troca;

\footnotetext{
${ }^{33}$ LEE, T.H. Statistical tables, methodology, data sources and conclusions regarding intersectoral capital flows in economic development of Taiwan, 1895-1960. Cornell, 1968. Prices, employment and income distribution research, Project. Paper n.12.

${ }^{34}$ ONU/ECAFE. Economic survey of Asia and the Far East. 1964. p.55-64.
} 
2) foco sobre a interdependência entre setores agrícola e não-agrícola via relação de função de produção e fluxos de mercado que ligam os setores — uso de insumos como fertilizantes, inseticidas e máquinas e suprimento de matérias-primas através dos efeitos para frente e para trás e os efeitos de mudanças na demanda final sobre o emprego e renda (o que chamam de estudo da "articulação setorial");

3) construção de um modelo de equilíbrio geral para estudar efeitos de variáveis exógenas (termos de troca, população, importação de produtos agrícolas, políticas econômicas).

Os autores apresentam uma definição dos fluxos entre setores com base nos trabalhos de Fei \& Ranis ${ }^{35}$, Lee $^{36}$ e $\operatorname{Lin}^{37}$. A definição é baseada em contabilidade social setorial, como apresentado no Quadro 1.

${ }^{35}$ Op. cit.

${ }^{36}$ LEE, T.H. Intersectoral capital flows in the economic development od Taiwan, 1895-1960. Ithaca: Cornell University Press, 1971.

${ }^{37}$ LIN, W.L. Economic interactions in Taiwan: a study of sectoral flows and linkages. Stanford, 1973. Dissertation $(\mathrm{PhD})$ - Stanford University. 
Quadro 1. Equações contábeis para fluxos setoriais de capital.

\begin{tabular}{|c|c|}
\hline Entradas & \\
\hline \multicolumn{2}{|l|}{ EQUAÇÕES SETORIAIS } \\
\hline \multicolumn{2}{|l|}{ Setor de Produção Não-Agrícola } \\
\hline \multicolumn{2}{|l|}{$\begin{aligned} X_{n n}+X_{a n}+L_{a n}+L_{n n}+K_{a n}+K_{n n n}+ & \\
X_{m n}= & C_{n n}+C_{n a}+C_{n g}+X_{n a}+X_{n n}+I_{n n}+I_{n a} \\
& +E_{n}\end{aligned}$} \\
\hline \multicolumn{2}{|l|}{ Setor Famílias Não-Agrícolas } \\
\hline$C_{n n}+C_{a n n}+S_{n n}+G_{n}+C_{n n n}=L_{n n}+K_{n n}+K_{n a}$ & $(3.5 .2)$ \\
\hline \multicolumn{2}{|l|}{ Setor de Produção Agrícola } \\
\hline $\begin{array}{l}X_{a a}+X_{n a}+L_{a a}+K_{a a}+K_{n a}+X_{m a}=C_{a a}+C_{a n}+X_{n a}+X_{a a}+I_{a u}+E_{a} \\
\text { Setor Famílias Agrícolas }\end{array}$ & $(3.5 .3)$ \\
\hline$C_{a a}+C_{n a}+S_{a a}+G_{a}+C_{m a}=L_{a u}+L_{a n}+K_{a u}+K_{a n}$ & $(3.5 .4)$ \\
\hline \multicolumn{2}{|l|}{ Governo } \\
\hline$C_{n g}+S_{g}=G_{a}+G_{n}$ & $(3.5 .5)$ \\
\hline \multicolumn{2}{|l|}{ Comércio Exterior } \\
\hline $\begin{array}{l}\qquad \begin{array}{l}F=X_{m n}+X_{m a}+C_{m n}+C_{m a}-E_{n}-E_{a} \\
\text { CLEARING EQUATIONS PARA O SISTEMA }\end{array}\end{array}$ & $(3.5 .6)$ \\
\hline$S_{n n}+S_{a a}+S_{g}=\begin{array}{l}I_{m n}+I_{n a}+I_{a a}+E_{n}+E_{a}-\left(X_{m n}+\right. \\
\left.X_{m a}+C_{m n}+C_{m a}\right)\end{array}$ & $(3.5 .7)$ \\
\hline $\begin{array}{l}\qquad I_{n n}=S_{n n}+\left(S_{a a}-I_{a a}\right)-I_{n a}+S_{g}+F \\
\text { CLEARING EQUATIONS PARA A AGRICULTURA }\end{array}$ & $(3.5 .7 \mathrm{a})$ \\
\hline $\begin{array}{r}\left(X_{a n}+C_{a n}\right)-\left(X_{n a}+C_{n a}+E_{a}\right)-\left(X_{m a}+\right. \\
\left.C_{m a}\right)+\left(K_{a n}-K_{n a}\right)+L_{a n}+\left(I_{a a}-S_{a a}\right)- \\
G_{a}=B\end{array}$ & $(3.5 .8)$ \\
\hline $\begin{aligned}\left(X_{a n}+C_{a n}+E_{a}\right)-\left(X_{n a}+C_{n a}+I_{a}\right)+ \\
\left(K_{a n}-K_{n a}+L_{a n}\right)+G_{a}=B\end{aligned}$ & $(3.5 .9)$ \\
\hline
\end{tabular}

Fonte: Yotopoulos \& Nugent (1976).

Nota: o primeiro subscrito indica a origem e o segundo o destino do fluxo. Um único subscrito indica o setor em relação ao qual se dá determinada atividade. Os símbolos são: setor agrícola (a), não-agrícola (n), importações $(\mathrm{m})$, governo $(\mathrm{g})$, bens intermediários $(\mathrm{X})$, fator primário trabalho (L), fator primário capital $(\mathrm{K})$, consumo (C), investimento (I), poupança (S), exportações (E), impostos ou subsídios (G), itens de balanceamento (B e F). 
A equação (3.5.7) é obtida a partir da soma das equações (3.5.1) a (3.5.5). A partir da equação (3.5.6), a primeira pode ser rescrita como (3.5.7a), definindo a formação de capital no setor não-agrícola. De seus componentes, a transferência líquida do setor agrícola consiste da diferença líquida entre poupança e investimentos no setor agrícola e entrada líquida de capital proveniente do setor não-agrícola $\left[\left(S_{\mathrm{aa}}-\mathrm{I}_{\mathrm{a} a}\right)-\mathrm{I}_{\mathrm{na}}\right]$. A transferência de recursos a partir do setor agrícola pode ser visualizada analisando exclusivamente tal setor. Para simplificar a equação (3.5.8), toma-se $I_{a}=\left(S_{a a}-I_{a a}-I_{n a}-\right.$ $X_{\mathrm{ma}}-\mathrm{C}_{\mathrm{ma}}$ ), chegando a (3.5.9). Nesta, o fluxo de capital a partir do setor agrícola (B) é representado por três componentes: a diferença entre o total de venda de produtos agrícolas e o total de compra de produtos não-agrícolas (definida nos dois primeiros parênteses), mais um termo de transferência de fatores primários e um termo de transferências governamentais. Para considerar as possíveis transferências via mudanças nos termos de troca, os autores calculam o fluxo real (B') usando quatro índices de preços: preços agrícolas $\left(\mathrm{P}_{\mathrm{a}}\right)$, não-agrícolas $\left(\mathrm{P}_{\mathrm{n}}\right)$, de fatores $\left(\mathrm{P}_{\mathrm{f}}\right)$ e índice geral de preços (P), ou seja:

$$
\begin{aligned}
B^{\prime}= & \left(X_{a n}+C_{a n}+E_{a}\right) / P_{a}-\left(X_{n a}+C_{n a}+I_{a}\right) / P_{n} \\
& +\left(K_{a n}-K_{n a}+L_{a n}\right) P_{f}+G_{a} / P
\end{aligned}
$$

A equação (3.5.10) pode ser rescrita de forma a separar o fluxo real de capital e os efeitos dos termos de troca:

$$
\begin{aligned}
B^{\prime}= & B / P_{a}+\left[\left(X_{n a}+C_{n a}+I_{a}\right) / P_{n}\right]\left[\left(P_{n} / P_{a}\right)-I\right] \\
& -\left[\left(K_{a n}-K_{n a}+L_{a n}\right) / P_{f}\right]\left[\left(P_{f}-P_{a}\right)-1\right]-G_{a} / P\left[\left(P / P_{a}\right)-1\right]
\end{aligned}
$$

O primeiro termo representa o fluxo real visível de capital. Em outras palavras, a diferença entre o total das vendas de produtos agrícolas e o total das compras de produtos não-agrícolas, deflacionada pelo índice de preços agrícolas. Os termos restantes constituem o fluxo real invisível de capital, que capta as mudanças nos termos de troca entre o setor agrícola e o não-agrícola, o mercado de fatores e o produto global. 


\subsection{Johnston \& Kilby (1977)}

Para Johnston \& Kilby (1977), os fluxos entre a agricultura e outros setores podem ser vistos como o resultado líquido da transferência bruta de recursos da agricultura - composta de impostos, poupança voluntária, pagamentos de aluguéis e juros e transferências invisíveis — e os ingressos no setor agrícola — despesas do governo em bens públicos como pesquisa e extensão, subsídios a insumos, investimentos em infra-estrutura rural, investimentos privados de setores não-agrícolas, provisão de fundos de empréstimos através de intermediários financeiros, pagamentos de renda recebida do setor não-agrícola por membros das famílias rurais. O melhor método, segundo os autores, para estimar a magnitude das transferências visíveis (impostos, poupanças, aluguéis), é calcular os fluxos gerais de bens entre a agricultura e o resto da economia, pois tais transferências estão forçosamente ligadas a um excedente de vendas do setor agrícola sobre suas compras.

\subsection{Mundle (1977)}

Para Mundle (1977), a transferência líquida de capital ou financeira nada mais é que o excesso de renda em relação aos gastos do setor agrícola. Essa diferença corresponde à balança comercial entre os setores agrícola e não-agrícola ou ao excedente de exportação do setor agrícola vis-à-vis o não agrícola — uma forma indireta de estimação dos fluxos financeiros. Em termos empíricos, tal excedente é tratado como a diferença entre a absorção de commodities (bens de consumo e/ou de produção) agrícolas pelo setor não-agrícola e a absorção de commodities não-agrícolas pelo setor agrícola. Para tanto, o autor estima um fluxo intersetorial de bens de consumo e outro de bens de produção, a preços constantes e correntes. A estimativa do fluxo completo é feita pela soma destes dois fluxos, após alguns ajustes para o comércio exterior (o resto do mundo é considerado como parte do setor não-agrícola, ou seja, as remessas do setor agrícola para o não-agrícola incluem o consumo de commodities agrícolas pelo setor 
não-agrícola, menos o total de importações dessas commodities do resto do mundo, mais o total das exportações agrícolas para o resto do mundo).

Segundo este autor, a definição do limite entre os setores obedece a um critério prático: disponibilidade de dados. Além disso, envolve a necessidade de minimizar os erros associados à junção de dados provenientes de diferentes fontes, que mudam ao longo do tempo e que nem sempre são adequadas ao tipo de estudo em questão. Isto está de acordo com Millar (1970), para o qual um teste de hipótese de um excedente agrícola requer conceito/definição que possibilite sua verificação empírica. Diferentes conceitos podem ser classificados de acordo com os critérios utilizados para definir o que é ou não excedente, e quais fronteiras/divisas definidas entre o que é setor agrícola e não-agrícola

Mundle comenta que o uso de preços ao consumidor de bens de consumo é adequado para as remessas do setor não-agrícola para o agrícola. Já para o consumo de produtos agrícolas pelo setor não-agrícola deveria ser preço ao produtor, uma vez que os serviços de comercialização e transporte são tratados como atividades não-agrícolas.

\subsection{Colomé (1978)}

Colomé (1978) apresenta a seguinte derivação/definição do excedente financeiro do setor agropecuário $\left(\mathrm{EF}_{\mathrm{a}}\right)$ :

$E_{a}=Y_{a}-C_{a a}$

Onde:

$\mathrm{E}_{\mathrm{a}}$ : excedente agropecuário;

$\mathrm{Y}_{\mathrm{a}}$ : renda agropecuária; e,

$\mathrm{C}_{\mathrm{aa}}$ : consumo de bens agropecuários pelo próprio setor.

A poupança agropecuária $\left(S_{a}\right)$ é definida como: 
$S_{a}=E_{a}-C_{n a}=Y_{a}-C_{a}$

Onde:

$\mathrm{C}_{\mathrm{na}}$ : consumo de bens não-agrícolas pelo setor agropecuário; e,

$\mathrm{C}_{\mathrm{a}}$ : consumo total da agropecuária.

$\mathrm{O} \mathrm{EF}_{\mathrm{a}}$ é então definido por:

$E F_{a}: S_{a}-I_{a}$

Onde o $I_{a}$ é o investimento agropecuário, que compreende:

$I_{\mathrm{aa}}$ : investimentos realizados no setor agrícola que consistem na aquisição de bens cuja origem é o próprio setor, quase sempre estimados pelas variações em estoques. Outros exemplos são aquisição de reprodutores e madeira para cercas; e,

$I_{\text {na: }}$ investimentos em bens de origem não-agrícola.

As críticas de Colomé aos trabalhos de Teubal $(1971$, 1975) repousam sobre a forma de estimação do consumo e sobre a definição do $\mathrm{EF}_{\mathrm{a}}$. O consumo é subestimado em razão de uma subestimação da renda agropecuária, pois Teubal usa, como medida da distribuição setorial de renda, a relação entre as rendas dos assalariados nos dois setores (sendo que a participação dos assalariados na renda agropecuária é menor que a existente no setor não-agrícola). Além disso, esse último autor não considera o $\mathrm{I}_{\mathrm{aa}}$. Tais problemas levam, segundo Colomé, a uma superestimação do $\mathrm{EF}_{\mathrm{a}}$.

\subsection{Mundle \& Ohkawa (1979)}

Mundle \& Ohkawa (1979) apresentam dois problemas conceituais nas medidas de fluxos de excedentes agrícolas: o primeiro refere-se à própria definição do setor agrícola e o segundo à mensuração em si. Segundo os autores, há diversas formas de se 
separar a economia para medir relações setoriais, sendo necessário tornar explícito o que está sendo medido. Os autores apresentam alguns exemplos de partições da economia:

a) entre as atividades puramente agrícolas (A) e o resto da economia (divisa 1 na Figura $1)$;

b) entre o setor famílias agrícolas, que inclui as atividades agrícolas e algumas atividades não-agrícolas das famílias agrícolas (FA), e o resto da economia (divisa 2 na Figura 1); ou,

c) entre o setor tradicional, que inclui todo o setor famílias agrícolas bem como manufaturas e serviços de pequena escala (TMS), e o setor manufatureiro moderno (SMM) (divisa 3 na Figura 1).

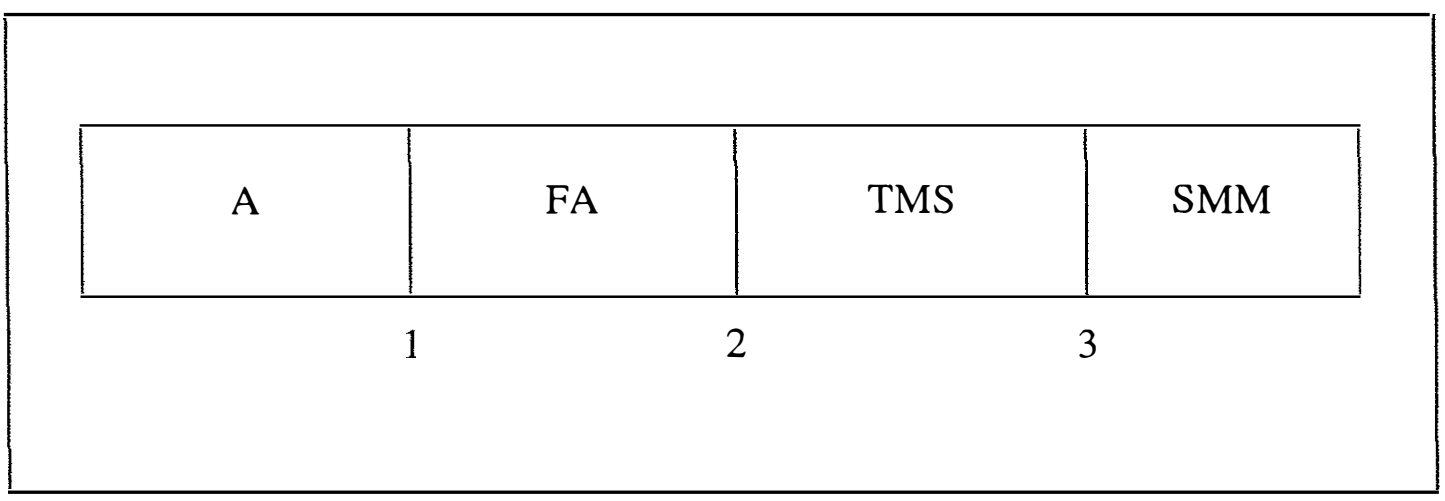

Figura 1: Possíveis divisões setoriais da economia.

Fonte: Mundle \& Ohkawa (1979).

Os autores comentam que os modelos dualistas geralmente trabalham na divisa 3. Por outro lado, as transferências de excedente são normalmente analisadas com base na divisa 2. Em seu trabalho, Mundle \& Ohkawa (1979) estão interessados em medir o fluxo que pode deixar o setor agrícola, trabalhando então na divisa 1 da Figura 1. Tal escolha foi determinada principalmente pela disponibilidade de dados, e não porque os autores a considerassem necessariamente a mais apropriada. 
O segundo aspecto importante é a definição do excedente agrícola, no sentido de um fluxo líquido de recursos a partir de tal setor. Para tanto, os autores partem de um sistema de contabilidade de pagamentos entre os setores agrícola e não-agrícola, mostrado no Quadro 2. Segundo eles, o grande problema é a estimação do consumo do setor agrícola, o maior item dos gastos do setor. Eles dispunham de estimativas anteriores sobre o consumo do setor rural e precisavam chegar a estimativas do setor agrícola. Citam que podem existir um grande número de formas de ajustar tais estimativas e listam três delas: a razão entre a população agrícola e a população rural, entre o total de horas trabalhadas nos dois setores, e entre o valor adicionado bruto dos setores. Esta última foi a utilizada por eles. 
Quadro 2. Contabilidade de pagamento entre os setores agrícola e não-agrícola.

\begin{tabular}{|c|c|}
\hline Recebimentos & Pagamentos \\
\hline (1) De exportações para o setor não-agrícola & (2) Por importações do setor não-agrícola \\
\hline a) exportação de bens de consumo & a) importação de bens de consumo \\
\hline b) exportação de bens intermediários & b) importação de bens intermediários \\
\hline c) exportação de bens de capital & c) importação de bens de investimento \\
\hline $\begin{array}{l}\text { d) pagamentos de impostos em espécie } \\
\text { (recebimento nominal) }\end{array}$ & $\begin{array}{l}\text { d) investimentos governamentais } \\
\text { (pagamento nominal por componentes } \\
\text { importados) }\end{array}$ \\
\hline $\begin{array}{l}\text { (3) Pagamentos por serviços de fatores pelo } \\
\text { setor agrícola }\end{array}$ & $\begin{array}{l}\text { (4) Pagamentos por serviços de fatores pelo } \\
\text { setor não-agrícola }\end{array}$ \\
\hline a) aluguéis, juros e lucros & a) aluguéis, juros e lucros \\
\hline $\begin{array}{l}\text { b) salários por ocupações suplementares } \\
\text { fora da agricultura }\end{array}$ & $\begin{array}{l}\text { b) salários por serviços de trabalho de } \\
\text { fanílias não-agrícolas }\end{array}$ \\
\hline $\begin{array}{l}\text { (5) Transferências correntes do setor não- } \\
\text { agrícola }\end{array}$ & $\begin{array}{l}\text { (6) Transferências correntes para o setor não- } \\
\text { agrícola }\end{array}$ \\
\hline $\begin{array}{l}\text { a) transferências privadas (presentes, } \\
\text { remessas de dinheiro) }\end{array}$ & $\begin{array}{l}\text { a) transferência privadas (presentes, } \\
\text { remessas de dinheiro) }\end{array}$ \\
\hline $\begin{array}{l}\text { b) transferências governamentais } \\
\text { (subsídios) }\end{array}$ & b) transferências para o governo (impostos) \\
\hline $\begin{array}{l}\text { (7) Transferências de capital do setor não- } \\
\text { agrícola }\end{array}$ & $\begin{array}{l}\text { (8) Transferências de capital para o setor não- } \\
\text { agrícola }\end{array}$ \\
\hline $\begin{array}{l}\text { a) compra de ativos e investimentos no setor } \\
\text { agrícola pelo setor não-agrícola }\end{array}$ & $\begin{array}{l}\text { a) compra de ativos e investimentos no setor } \\
\text { não-agrícola pelo setor agrícola }\end{array}$ \\
\hline $\begin{array}{l}\text { b) investimento governamental no setor } \\
\text { agrícola }\end{array}$ & \\
\hline
\end{tabular}

Fonte: Mundle \& Ohkawa (1979).

Baseado no sistema de contas do Quadro 2, é possível definir alguns conceitos importantes e dentre eles, as duas definições de excedente agrícola usadas pelos autores: 
a) Balanço de comércio ou excedente comercial $\left(\mathrm{AS}^{*}\right)$ do setor agrícola $[=(1)-(2)]$ : mede o excedente líquido no valor dos bens e serviços fornecidos e adquiridos pelo setor agrícola ${ }^{38}$;

b) Balanço de pagamento de renda de fatores $\left(\mathrm{F}_{\mathrm{NA}}\right)$ ou recebimento líquido de pagamentos de fatores pela agricultura $[=(3)-(4)]$ : reflete o excesso de recebimentos de rendas de fatores pela agricultura em relação ao que é pago ao setor não-agrícola;

c) Balanço de outras transferências correntes $\left(\mathrm{O}_{\mathrm{NA}}\right)$ ou recebimento líquido de outras transferências correntes pela agricultura em relação ao que é pago ao setor nãoagrícola $[=(5)-(6 a)]$. Como o pagamento de taxas é visto como uma poupança forçada extraída regularmente da agricultura é tratado na conta de capital como uma saída de poupança;

d) Balanço de transferências de capital ou excedente de poupança (AS). É a saída líquida de capital de investimento da agricultura em relação à entrada de tais investimentos provenientes do setor não-agrícola $[=(8)+(6 b)-(7)]$. O excedente de poupança pode ser escrito como:

AS = exportação total de capital - importação total de capital investimentos governamentais (GI) + pagamento de impostos $\left(\mathrm{T}_{\mathrm{A}}\right)$

Como a exportação líquida de capital corresponde à diferença entre a poupança privada $\left(S_{A}\right)$ e o investimento fixo na agricultura $\left(I_{F A}\right)$, tem-se:

$$
A S=S_{A}-I_{F A}-G I+T_{A}
$$

e) Como os recebimentos e pagamentos devem se igualar no sentido ex post, tem-se a identidade:

\footnotetext{
${ }^{38}$ Note que este conceito se aproxima do utilizado por Mundle (1977).
} 
$(1)+(3)+(5)+(7)=(2)+(4)+(6 a)+(6 b)+(8)$

Da qual se obtém:

$[(1)-(2)]+[(3)-(4)]+[(5)-(6 a)]=[(8)+(6 b)-(7)]$

Ou, usando as notações acima:

$A S^{*}+F_{S A}+O_{N A}=A S$

De (3.9.4) é possível observar que a diferença entre o excedente de poupança (AS) e o de comércio (AS*) é equivalente à soma do fluxo líquido de renda de fatores $\left(\mathrm{F}_{\mathrm{NA}}\right)$ e outras transferências correntes $\left(\mathrm{O}_{\mathrm{NA}}\right)$.

$A S-A S^{*}=F_{N A}+O_{N A}$

Os autores chamam a atenção para o fato de o setor externo, não explicitado, poder ser visto como implicitamente incluído no setor não-agrícola. Além disso, Mundle \& Ohkawa ignoram as transferências invisíveis originadas de alterações nos termos de troca setoriais, pois trabalham com preços correntes.

\subsection{Gutierrez \& Barbero (1988)}

Gutierrez \& Barbero (1988) apresentam a seguinte seqüência para a definição do $\mathrm{EF}_{\mathrm{a}}$ semelhante àquela proposta por Colomé (1978):

$A_{s}=Y_{a}-C_{a}$

$E F_{a}=S_{a}-I_{a}$

Onde:

$\mathrm{Y}_{\mathrm{a}}$ : produto bruto do setor (VBP - insumos intermediários);

$\mathrm{C}_{\mathrm{a}}$ : consumo per capita do país multiplicado pela população agropecuária; e, 
$\mathrm{I}_{\mathrm{a}}$ : incorporação de capital proveniente da agropecuária e de outros setores, mais as variações de estoques agrícolas e pecuários.

A diferença entre os trabalhos de Colomé (1978) e Gutierrez \& Barbero está na forma de cálculo do $\mathrm{C}_{\mathrm{a}}$. Colomé supõe que os assalariados do setor consomem toda sua renda, isto é, têm uma propensão média a consumir igual a um, enquanto os produtores têm uma propensão média a consumir menor que a unidade (despendem parte da renda em consumo). Já Gutierrez \& Barbero tomam o consumo per capita da população total e multiplicam pela população rural.

Tanto estes autores quanto Colomé criticam Teubal por não considerar $I_{a a}$. Nisto estão de acordo com Alves et al. (1996) por considerarem que também os investimentos realizados no próprio setor agrícola são importantes, pois são parte do investimento agregado da economia, cujos fundos provêm deste setor.

\subsection{Morrison \& Thorbecke (1990)}

Morrison \& Thorbecke (1990) tomam o excedente financeiro agrícola como a transferência líquida entre os setores agrícola (A) e não-agrícola $(\mathrm{N})$, destacando a importância dos serviços governamentais que beneficiam o setor agrícola. Dada a quantidade de trabalhos com noções diferentes e conflitantes do excedente agrícola, os autores propõem uma definição do conceito mais rigorosa e não-ambígua, baseada na estrutura de uma Matriz de Contabilidade Social - MCS - que aparece no Quadro 3. Esta abordagem permite superar o problema das interrelações/interdependência entre setores, pois todas as relações entre atividades, instituições e agentes são consideradas.

Os autores definem o excedente agrícola como um fluxo não compensado de recursos do setor agrícola para o não-agrícola. É uma transferência líquida do setor agrícola para o resto da economia. A definição do excedente agrícola é feita em dois estágios: excedente doméstico e excedente externo. O excedente agrícola é a soma destes dois. 

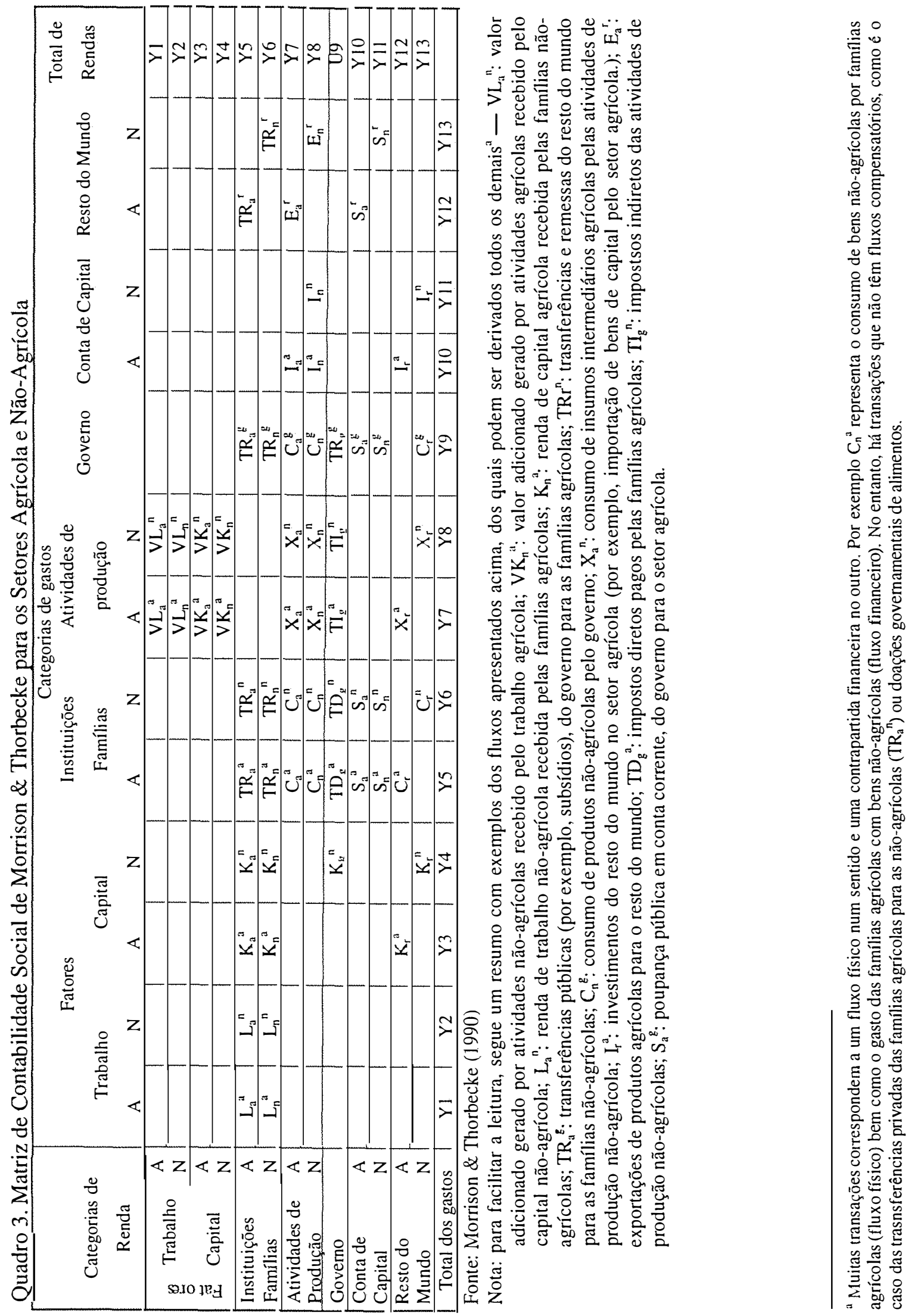
Como, por definição, a renda de uma conta se iguala ao dispêndio na mesma conta, pode-se obter da matriz (Quadro 3) as seguintes identidades para a obtenção do excedente doméstico:

Atividades de Produção Agrícola

$$
\begin{aligned}
C_{a}{ }^{a}+C_{a}{ }^{n}+X_{a}{ }^{a}+X_{a}{ }^{n} & +C_{a}{ }^{r}+I_{a}{ }^{a}+E_{a}{ }^{r}=V L_{a}{ }^{a}+V L_{n}{ }^{a}+V K_{a}{ }^{a}+ \\
& +V K_{n}{ }^{a}+X_{a}{ }^{a}+X_{n}{ }^{a}+T I_{g}{ }^{a}+X_{r}{ }^{a}
\end{aligned}
$$

Atividades de Produção Não-Agrícola

$$
\begin{aligned}
C_{n}{ }^{a}+C_{n}{ }^{n}+X_{n}{ }^{a}+X_{n}{ }^{n} & +C_{n}{ }^{g}+I_{n}{ }^{a}+I_{n}{ }^{n}+E_{n}{ }^{r}=V L_{a}{ }^{n}+V L_{n}{ }^{n}+ \\
& +V K_{a}{ }^{n}+V K_{n}{ }^{n}+X_{a}{ }^{n}+X_{n}{ }^{n}+T I_{g}{ }^{n}+X_{r}{ }^{n}
\end{aligned}
$$

Setor Famílias Agrícolas

$$
\begin{aligned}
L_{a}{ }^{a}+L_{a}{ }^{n}+K_{a}{ }^{a}+K_{a}{ }^{n} & +T R_{a}{ }^{a}+T R_{a}{ }^{n}+T R_{a}{ }^{\prime}+T R_{a}{ }^{r}=T R_{a}{ }^{a}+ \\
& +T R_{n}{ }^{a}+C_{a}{ }^{a}+C_{n}{ }^{a}+T D_{g}{ }^{a}+S_{a}{ }^{a}+S_{n}{ }^{a}+C_{r}{ }^{a}
\end{aligned}
$$

Setor Famílias Não-Agrícolas

$$
\begin{aligned}
L_{n}{ }^{a}+L_{n}{ }^{n}+K_{n}{ }^{a}+K_{n}{ }^{n} & +T R_{n}{ }^{a}+T R_{n}{ }^{n}+T R_{n}{ }^{g}+T R_{n}{ }^{r}=T R_{a}{ }^{n}+ \\
& +T R_{n}{ }^{n}+C_{a}{ }^{n}+C_{n}{ }^{n}+T D_{g}{ }^{n}+S_{a}{ }^{n}+S_{n}{ }^{n}+C_{r}{ }^{n}
\end{aligned}
$$

Conta Corrente do Trabalho Agrícola

$$
V L_{a}{ }^{a}+V L_{a}{ }^{n}=L_{a}{ }^{a}+L_{n}{ }^{a}
$$

Conta Corrente do Trabalho Não-Agrícola

$$
V L_{n}{ }^{a}+V L_{n}{ }^{n}=L_{a}{ }^{n}+L_{n}{ }^{n}
$$

Conta Corrente do Capital Agrícola 
$V K_{a}^{a}+V K_{a}{ }^{n}=K_{a}{ }^{a}+K_{n}{ }^{a}+K_{r}^{a}$

Conta Corrente do Capital Agrícola

$V K_{n}{ }^{a}+V K_{n}{ }^{n}=K_{a}{ }^{n}+K_{\prime}^{\prime}{ }^{n}+K_{g}{ }^{n}+K_{r}^{n}$

Governo

$$
\begin{aligned}
K_{g}{ }^{n}+T D_{g}{ }^{a}+T D_{g}{ }^{n}+ & T I_{g}{ }^{a}+T I_{g}{ }^{n}+T R_{g}{ }^{g}=T R_{a}{ }^{g}+T R_{n}{ }^{g}+ \\
& +C_{a}{ }^{g}+C_{n}{ }^{g}+T R_{g}{ }^{g}+S_{a}{ }^{g}+S_{n}{ }^{g}+C_{r}{ }^{g}
\end{aligned}
$$

Setor de Capital Agrícola

$S_{a}{ }^{a}+S_{a}{ }^{n}+S_{a}{ }^{g}+S_{a}{ }^{r}=I_{a}{ }^{a}+I_{n}{ }^{a}+I_{r}^{a}$

Setor de Capital Não-Agrícola

$S_{n}{ }^{a}+S_{n}{ }^{n}+S_{n}{ }^{g}+S_{n}{ }^{r}=I_{l}{ }^{n}+I_{r}{ }^{n}$

Conta do Setor Agrícola com o Resto do Mundo

$K_{r}^{a}+C_{r}^{a}+X_{r}^{a}+I_{r}^{a}=T R_{a}^{r}+E_{a}^{r}+S_{a}^{r}$

Conta do Setor Não-Agrícola com o Resto do Mundo

$K_{r}^{n}+C_{r}^{n}+X_{r}^{n}+C_{r}^{g}+I_{r}^{n}=T R_{n}{ }^{r}+E_{n}{ }^{r}+S_{n}{ }^{r}$

Pela adição das equações (3.11.1), (3.11.3), (3.11.5), (3.11.7), (3.11.10), e (3.11.12), com os termos rearranjados, obtém-se a expressão:

$\left[\left(C_{a}{ }^{n}+C_{a}{ }^{g}+X_{a}{ }^{n}+V L_{a}{ }^{n}+V K_{a}{ }^{n}\right)-\left(C_{n}{ }^{a}+X_{n}{ }^{a}+V L_{n}{ }^{a}+V K_{n}{ }^{a}\right)\right]+$ 


$$
+\left[\left(L_{a}{ }^{n}+K_{a}{ }^{n}\right)-\left(L_{n}{ }^{a}+K_{n}{ }^{a}\right)\right]=
$$

$\mathrm{Bd}$

$=\left(T R_{n}{ }^{a}-T R_{a}{ }^{n}\right)+\left(S_{n}{ }^{a}-S_{a}{ }^{n}\right)+\left[\left(T D_{g}{ }^{a}+T I_{g}{ }^{a}\right)-\left(T R_{a}{ }^{g}+S_{a}{ }^{g}\right)\right]+I_{n}{ }^{a}$

Cd $\quad$ Dd $\quad$ Ed

$\mathrm{Ou}$,

$A d+B d=C d+D d+E d+I_{n}{ }^{a}$

Onde:

Ad: saída líquida de bens de consumo, insumos intermediários e insumos primários do setor agrícola para o não-agrícola;

Bd: saída líquida de serviços de trabalho e capital de A para $\mathrm{N}$, produzindo uma entrada líquida de rendas de salários e aluguéis de $\mathrm{N}$ para $\mathrm{A}$;

Cd: transferência monetária líquida de remessas privadas das famílias agrícolas para as não-agrícolas;

Dd: poupança líquida do setor agrícola para o não-agrícola;

Ed: transferência monetária líquida do setor agrícola para o governo; e,

$\mathrm{I}_{\mathrm{n}}{ }^{\mathrm{a}}$ : investimento do setor não-agrícola para o agrícola.

O lado esquerdo da equação (3.11.14a) ou (3.11.14b) representa o valor do excedente líquido de produtos e fatores do setor agrícola para o não-agrícola. É o excedente físico líquido de bens e recursos agrícolas. O lado direito de tais equações mostra os fluxos de capital e monetário compensatórios. Uma forma alternativa de interpretação indica que o investimento no setor agrícola pelo não-agrícola é igual à 
diferença entre a saída líquida física de bens e recursos agrícolas e os fluxos monetários líquidos para fora do setor agrícola.

O excedente agrícola doméstico pode então ser definido. É o fluxo líquido (monetário) do setor agrícola para o não-agrícola que pode ser usado para financiar os fluxos físicos líquidos do setor agrícola para o não-agrícola (alimentos, bens agrícolas e fatores agrícolas de produção para o setor não-agrícola). Em termos da equação (14a), tal excedente corresponde a $(\mathrm{Cd}+\mathrm{Dd}+\mathrm{Ed})$. No entanto, tal fluxo precisa ser corrigido em função de bens e serviços, agrícolas ou não, de alguma forma subsidiados, recebidos do governo pelas famílias agrícolas, não computados em Ed. Por exemplo, parte de $\mathrm{C}_{\mathrm{a}}{ }^{\mathrm{g}} \mathrm{e}$ $\mathrm{C}_{\mathrm{n}}{ }^{\mathrm{g}}$ pode ser fornecida gratuitamente ou a taxas subsidiadas para a população agrícola (ou não-agrícola), sejam eles bens (alimentos) ou serviços (subsídios à saúde, transporte). Desta forma, o termo $(\mathrm{Cd}+\mathrm{Dd}+\mathrm{Ed})$ tem que ser corrigido por um "equivalente de subsídio", da seguinte forma: se $\alpha(1 \geq \alpha \geq 0)$, pode-se representar tal equivalente por:

$\alpha\left(C_{a}^{g}+C_{n}^{g}\right)=F d$

Onde Fd é o valor monetário dos bens e serviços gratuitos ou subsidiados recebidos do governo pelas famílias agrícolas. Desta forma, a equação (3.11.14b) pode ser rescrita como:

$A d+B d-F d=C d+D d+E d-F d+I_{n}{ }^{a}$

O excedente agrícola doméstico, SUd, pode ser definido como:

$S U d=C d+D d+E d-F d=A d+B d-I_{a}{ }^{n}-F d$

O excedente agrícola externo (SUf) é obtido rescrevendo a equação (3.11.12) como:

$\left[E_{a}^{r}-\left(C_{r}^{a}+X_{r}^{a}\right)\right]-K_{r}^{a}=-T R_{a}^{r}-S_{a}^{r}+I_{r}^{a}$

Af $\quad$ Bf $\quad$ Cf $\quad$ Df 
$\mathrm{Ou}$

$A f+B f=C f+D f+I_{r}^{a}$

Onde:

Af: excedente líquido de exportação do setor agrícola;

Bf: fluxo físico líquido de fatores entre o setor agrícola e o resto do mundo;

Cf: remessas privadas do exterior para as famílias do setor agrícola; e,

Df: excedente na conta corrente do balanço de pagamentos do setor agrícola vis-à-vis o resto do mundo.

O lado esquerdo da equação (3.11.18a) ou (3.11.18b) representa o valor do excedente líquido de produtos do setor agrícola para o resto do mundo e o serviço do capital líquido. No lado direito estão os fluxos monetários compensatórios. De forma análoga ao caso doméstico, o excedente externo poderia ser definido como ( $\mathrm{Cf}+\mathrm{Df}$ ), mas é necessário também neste caso o ajuste para um equivalente de subsídios, $\beta$ $(1 \geq \beta \geq 0)$. Logo,

$\beta C_{r}^{g}=F f$

Onde Ff é o equivalente externo de (3.11.15). Então, de (3.11.18b) e (3.11.19), o SUf pode ser escrito como:

$S U f=C f+D f-F f=A f+B f-I_{r}^{a}-F f$

O excedente agrícola total, SU, consiste de um componente doméstico e um externo:

$S U=S U d+S U f$ 
É importante destacar que, apesar da preocupação com uma definição rigorosa do excedente do setor agrícola, Morrison \& Thorbecke não consideraram a questão das transferências que podem ocorrer devido a mudanças nos termos de troca. Isto porque eles consideram/assumem que todas as transações são realizadas a preços de equilíbrio. Outro aspecto é que eles também fazem a análise do comportamento do componentes do excedente.

\subsection{Karshenas (1994)}

Karshenas (1994) cita que existem estudos em diferentes países sobre fluxos intersetoriais que podem ser úteis ao entendimento do papel da agricultura no financiamento da industrialização. ${ }^{39}$ Este autor também usa uma Matriz de Contabilidade Social, mais simplificada em função do problema de inexistência de dados sobre os fluxos de bens, serviços e fatores de produção. A MCS sugerida por Karshenas é apresentada no Quadro 4.

\footnotetext{
${ }^{39}$ Não somente a indústria, mas outros setores de forma geral, ou seja, também o setor serviços.
} 


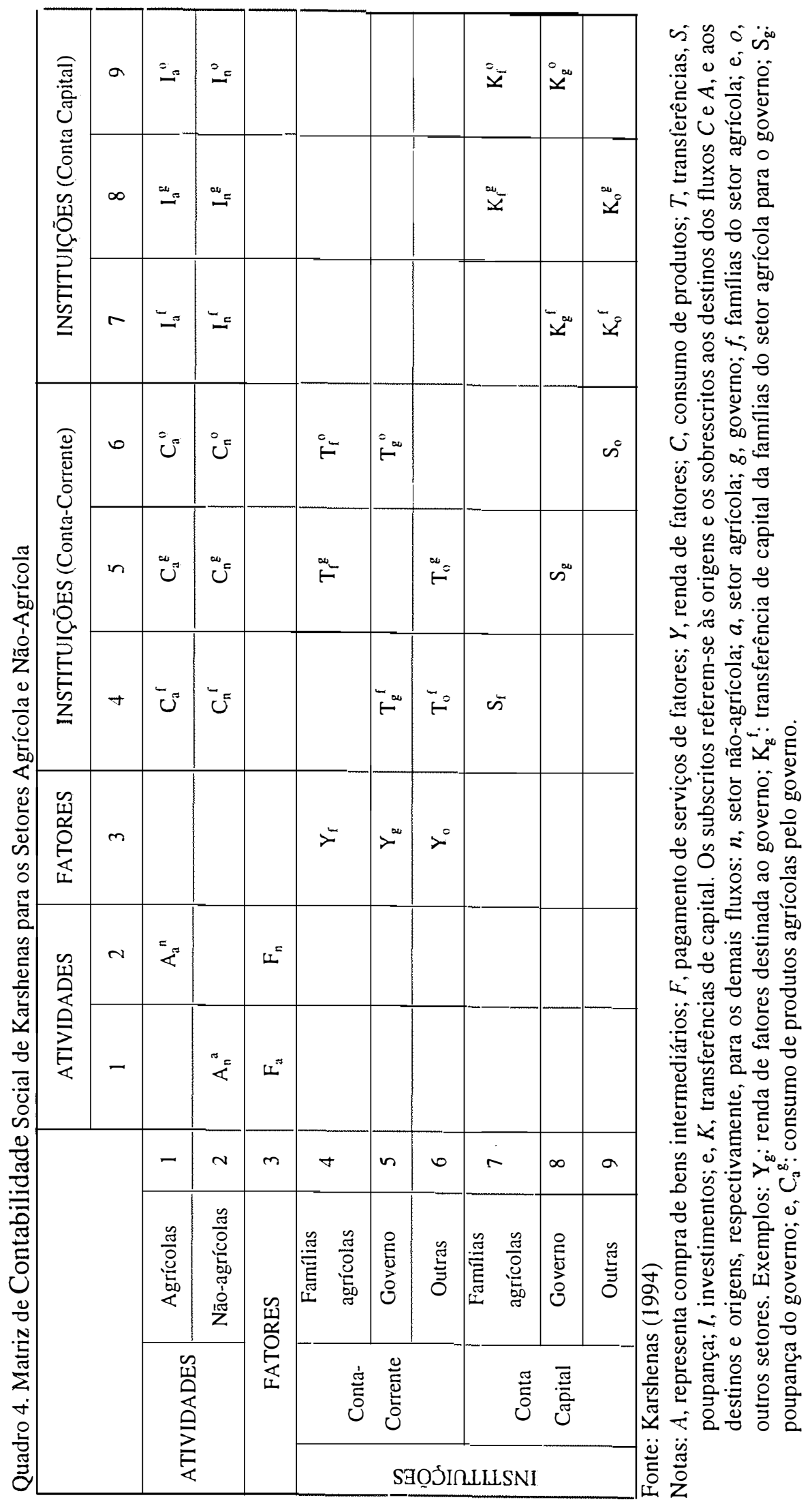


Seguindo as deduções apresentadas em Karshenas (1994) (e também em Evangelista, 1997), tem-se a seguinte definição do excedente financeiro do setor agrícola. A contribuição financeira do setor agrícola depende do balanço das "exportações"40 e "importações" deste setor.

$R=X_{a}-M_{a}$

Com:

R: excedente das “exportações” (do setor agrícola para o setor não-agrícola);

$\mathrm{X}_{\mathrm{a}}$ : valor corrente das "exportações"; e,

$\mathrm{M}_{\mathrm{a}}$ : valor corrente das "importações”.

De acordo com a matriz do Quadro 4:

$X_{a}=A_{a}{ }^{n}+C_{a}{ }^{g}+C_{a}{ }^{o}+I_{a}{ }^{g}+I_{a}{ }^{o}$

e

$M_{a}=A_{n}{ }^{a}+C_{n}^{f}+I_{n}^{f}$

Da igualdade entre a linha 1 e a coluna 1 :

$A_{a}{ }^{n}+C_{a}{ }^{f}+C_{a}{ }^{g}+C_{a}{ }^{o}+I_{a}^{f}+I_{a}{ }^{g}+I_{a}{ }^{o}=A_{n}{ }^{a}+F_{a}$

Passando $\mathrm{C}_{\mathrm{a}}{ }^{\mathrm{f}}$ e $\mathrm{I}_{\mathrm{a}}{ }^{\mathrm{f}}$ para o lado direito de (3.12.4),

$A_{a}{ }^{n}+C_{a}{ }^{g}+C_{a}{ }^{o}+I_{a}{ }^{g}+I_{a}{ }^{o}=A_{n}{ }^{a}+F_{a}-C_{a}^{f}-I_{a}^{f}$

A expressão (3.12.2) equivale, então, a

$X_{a}=A_{n}^{a}+F_{a}-C_{a}^{f}-I_{a}^{f}$

${ }^{40}$ Destacado pois se refere a uma relação setorial, e não necessariamente com outros países. 
Substituindo (3.12.3) e (3.12.2') em (3.12.1) tem-se

$$
\begin{aligned}
R=X_{a}-M_{a} & =\left[A_{n}{ }^{a}+F_{a}-C_{a}^{f}-I_{a}^{f}\right]-\left[A_{n}{ }^{a}+C_{n}^{f}+I_{n}^{f}\right] \\
& =F_{a}-\left(C_{a}^{f}+C_{n}^{f}\right)-\left(I_{a}^{f}+I_{n}^{f}\right)
\end{aligned}
$$
(a)
(b)
(c)

Onde:

(a): valor adicionado pelo setor $\mathrm{A}$;

(b): consumo de bens finais total das famílias do setor agrícola, tanto de produtos agrícolas como de não-agrícolas; e,

(c): investimento total no setor agrícola, originado no próprio setor ou no setor nãoagrícola.

Usando estas expressões e de acordo com os fluxos e identidades (linha $4=$ coluna 4; linha 7 = coluna 7) da matriz, chega-se à expressão:

$$
R=\left(F_{a}-Y_{f}\right)-\left(K_{f}^{g}-K_{g}^{f}\right)-\left(K_{f}^{o}-K_{o}^{f}\right)-\left(T_{f}^{g}-T_{g}^{f}\right)-\left(T_{f}^{o}-T_{o}^{f}\right)
$$
(a)
(b)
(c)
(d)
(e)

Onde, em termos líquidos:

(a): fluxo renda de fatores;

(b): investimentos governamentais;

(c): investimentos privados;

(d): impostos e subsídios; e,

(e): transferências correntes privadas. 
A expressão (3.12.6) corresponde à forma algébrica financeira do excedente transferido pelo setor agrícola. Esta representação permite verificar os mecanismos através dos quais se dá a transferência de recursos entre o setor agrícola e os outros setores.

Karshenas considera os efeitos das variações nos termos de troca. O valor real do fluxo (r), com $\mathrm{P}_{x}$ e $\mathrm{P}_{\mathrm{m}}$ representando, respectivamente, os preços de venda e de compra do setor agrícola, é dado por:

$r=\left(X_{a} / P_{x}\right)-\left(M_{a} / P_{m}\right)=x_{a}-m_{a}$

Esta é a real contribuição da agricultura do ponto de vista da economia como um todo. Interessa neste caso o real valor dos fluxos disponibilizados por um setor, e os preços relativos não são tão importantes. No entanto, conforme verificado anteriormente em outros autores, os preços relativos são importantes do ponto de vista de um setor específico, ou seja, o valor real do excedente financeiro neste caso depende dos termos de troca entre as compras e as vendas do setor. A magnitude deste valor depende, obviamente, do índice de preços utilizado para deflacionar R. Sendo P tal índice, o valor real do fluxo do ponto de vista do setor e incluindo os efeitos dos termos de troca (r') seria dado por:

$r^{\prime}=\left(X_{c} / P\right)-\left(M_{c} / P\right)=(V+K) / P=R / P$

A diferença entre r e r' é a renda dos ganhos devido aos termos de troca (TT), então:

$r=x_{a}-m_{a}=\left(X_{a} / P\right)-\left(M_{a} / P\right)+T T$

Os ganhos em função de termos de troca para o setor agrícola são expressos por:

$T T=x_{a}\left[1-\left(P_{x} / P\right)\right]+m_{a}\left[\left(P_{m} / P\right)-1\right]$

A escolha do índice de preços é uma questão não resolvida. O autor cita como exemplo a sugestão de Ishikawa (1967a) de usar $\mathrm{P}_{\mathrm{x}}$ para excedente de exportação e $\mathrm{P}_{\mathrm{m}}$ 
para excesso de importação. Assumindo, por exemplo, $\mathrm{P}=\mathrm{P}_{\mathrm{x}}$, tem-se a seguinte expressão para a contribuição financeira líquida real do setor agrícola:

$r=x_{a}-m_{a}=\left[(V+K) / P_{x}\right]+T T$

ou

$r=R / P_{x}+M_{a} / P_{m}\left[\left(P_{m} / P_{x}\right)-1\right]$

A expressão (3.12.11) é equivalente à versão da expressão (3.2.1) de Ishikawa (1967) destinada a medir o excedente de exportações $(R=X-M)$.

Outra noção de excedente financeiro, de acordo com Karshenas (1994), é a do “excedente agrícola líquido" — o $\mathrm{NS}_{\mathrm{a}}$. É definido, a partir de Millar (1970), como o valor adicionado no setor agrícola menos o consumo da famílias do mesmo setor. Pode ser definido, a partir do Quadro 4, como:

$N S_{a}=F_{a}-\left(C_{a}^{f}+C_{n}^{f}\right)=\left(X_{a}-M_{a}\right)+\left(I_{a}^{f}+I_{n}^{f}\right)$

ou

$N S_{a}=F_{a}-C_{a}=\left(I_{a}+X_{a}-M_{a}\right)$

O $\mathrm{NS}_{\mathrm{a}}$ é uma noção útil pois se refere aos recursos disponibilizados para investimento no próprio setor agrícola e nos outros setores, inclusive nas exportações. Outra utilidade é que possibilita conhecer a direção do fluxo nos casos em que os fluxos de saída não podem ser especificados devido a problemas de dados.

\subsection{Evangelista (1997)}

Evangelista (1997) lembra que a existência de um excedente está implícita nas diversas considerações sobre o papel da agricultura no desenvolvimento econômico. 
Além disso, cita que o excedente pode ser basicamente de três tipos: de produto, de mãode-obra e financeiro.

Este autor trabalha com uma abordagem baseada na de Karshenas (1994) ${ }^{41}$, com as modificações apresentadas a seguir. Neste caso, as variáveis explicitadas são:

- Capital oficial, isto é, Formação Bruta de Capital Fixo do governo no setor agrícola;

- Capital privado, isto é, Formação Bruta de Capital Fixo privada no setor agrícola. Evangelista considera que só existiam entradas no setor. Difere de Karshenas (1994) pois este último teve que se valer de medidas indiretas;

- Renda Líquida de Fatores, obtida a partir de uma estrutura de receitas (recebimentos por aluguel de pastos, terras, reprodutores e serviços prestados a terceiros) e despesas (salários, cota-parte, arrendamentos, serviços de empreitada, aluguel de máquinas, equipamentos e reprodutores). Com essa estrutura, são incluídos no cálculo os valores referentes a impostos, taxas e subsídios e recebimentos da previdência, ou seja, o fluxo de transferências correntes entre o setor agrícola e o governo $\left(\mathrm{T}_{\mathrm{f}}^{\mathrm{g}}-\mathrm{T}_{\mathrm{g}}^{\mathrm{f}}\right)$, que não foi utilizado por Karshenas (1994). Ademais, Evangelista considera que a estrutura das receitas e despesas seja constante entre os Censos Agropecuários.

O autor não conseguiu informações sobre as transferências correntes privadas $\left(\mathrm{T}_{\mathrm{f}}{ }^{\mathrm{O}}-\mathrm{T}_{\mathrm{o}}{ }_{\mathrm{f}}\right)$. Teve também problemas com os índices de preços usados para calcular o valor real dos fluxos. Como usou os Índices de Preços Pagos e Recebidos pelos produtores agrícolas (IPP e IPR) da Fundação Getúlio Vargas, que tiveram a metodologia de cálculo modificada em 1987, o autor teve que analisar duas séries de resultados, não comparáveis entre si. No cálculo dos subsídios, o autor utiliza taxas estimadas por Almeida (1994).

\footnotetext{
${ }^{41}$ Vale destacar que Evangelista (1997) não chegou a montar a matriz de contabilidade social. Utilizou-a somente para a definição dos componentes do excedente financeiro.
} 


\subsection{Considerações adicionais sobre as abordagens metodológicas}

Fica claro, a partir de trabalhos como o de Ishikawa (1967b) e o de Mundle (1977), entre outros, que dois fatores colaboram para a diversidade metodológica mostrada neste Capítulo. São eles a estrutura e organização da economia em particular e as informações disponíveis (metodologias de levantamento e tratamento dos dados primários, tipos de dados levantados etc.). O último autor também comenta sobre a dificuldade de comparar séries cujos conceitos mudam e que não foram preparadas especificamente para casos como esses. Ishikawa (1967a) destaca que a dificuldade de dados obriga o uso de informação indireta, não inteiramente relevante do ponto de vista conceitual, além de estatisticamente menos confiável.

As diferentes formas de mensurar o excedente financeiro do setor agrícola obviamente apresentam vantagens e desvantagens. Este item tem como objetivo discutir os pontos das diferentes abordagens mais relevantes para o presente estudo, auxiliando e justificando a abordagem escolhida e alguns outros itens específicos. As propostas metodológicas apresentadas anteriormente servem também para que se tenha noção de sua evolução.

A noção de excedente que permeia a maioria das abordagens é semelhante: a produção do setor agrícola não é totalmente consumida no mesmo, a diferença correspondendo a uma "poupança". A parte desta poupança não utilizada para investimentos no setor agrícola é então disponibilizada para outros setores. As principais diferenças são relativas aos cortes (agrícola/não-agrícola, rural/urbano), à forma de considerar as interdependências setoriais e às estimativas de consumo e investimento.

Ohkawa \& Rosovsky (1961) não especificam, por exemplo, a origem dos investimentos, e usam corte rural/urbano, semelhante ao utilizado por Ishikawa (1967a). Este último apresenta uma especificação mais detalhada dos componentes dos fluxos, inclusive indicando as origens e destinos de alguns deles. Além disso, aparece em seu trabalho a preocupação e a indicação de cálculo das transferências que ocorrem em função de mudanças nos termos de troca entre os setores. 
Ponto importante no trabalho de Teubal (1971) é o fato de, além de explicitar as origens e destinos dos fluxos, considerar somente os investimentos de origem nãoagrícola realizados no setor, ou seja, desconsidera todos os investimentos cuja origem dos bens é o próprio setor. Colomé (1978) propõe uma correção ao trabalho de Teubal ao considerar os investimentos em bens de origem agropecuária, que também são considerados no trabalho de Gutierrez \& Barbero (1988). Estes três trabalhos são importantes por apresentar alternativas de estimação do consumo no setor agrícola.

No trabalho de Millar (1971) aparece um modelo, simplificado, que explicita as origens e os destinos do fluxos considerados, chamando atenção para o fato de o modelo ser apropriado por considerar a interdependência que existe entre os setores. Yotopoulos \& Nugent (1976) e Mundle \& Ohkawa (1979) utilizam esquemas de contabilidade setorial, mais detalhada, para a definição do excedente financeiro. A diferença é que os últimos não consideram as transferência via termos de troca. Johnston \& Kilby (1977) afirmam que a melhor forma de estimar as transferências entre a agricultura e os outros setores é calcular os fluxos gerais de bens entre a agricultura e o resto da economia. Apesar de não considerar itens como relações entre atividades e instituições, tal trabalho é importante por confirmar (ou dar respaldo) à utilização de medidas do excedente pelo lado real da economia.

A definição de excedente de Mundle (1977) não considera explicitamente os investimentos. Sua contribuição para o presente estudo é o fato de chamar a atenção para um critério prático: a definição do limite entre os setores deve ocorrer em função da disponibilidade de dados (desde que não invalide os objetivos da pesquisa). Essa questão aparece também em Mundle \& Ohkawa (1979), que traz também importante contribuição a respeito da forma de estimação do consumo no setor agrícola.

Finalmente, tem-se as abordagens baseadas em Matrizes de Contabilidade Social (MCS) de Morrison \& Thorbecke (1990), Karshenas (1994) e Evangelista (1997). Sua utilização surge como tentativa de chegar a uma definição mais precisa do que seja o excedente financeiro do setor agrícola. Com isso, seriam resolvidas duas questões: a da 
diversidade de abordagens, que dificulta a comparação entre os resultados dos diferentes trabalhos e a da consideração das interações entre os setores (que obviamente depende de como os setores são definidos em tais matrizes). Além das diferenças nas matrizes, esses trabalhos diferem entre si pois Morrison \& Thorbecke não consideram a questão das transferências em função de mudanças nos termos de troca setoriais. Além disso, o trabalho de Evangelista é útil por indicar os índices de preços utilizados na mensuração deste tipo de transferência.

As Matrizes de Contabilidade Social são "uma forma simples e eficiente de armazenar dados econômicos. São, na realidade, um conjunto completo e consistente de informações com todas as transações entre setores e agentes: consistente pois para cada renda gerada há um gasto correspondente, e completo, uma vez que tanto o agente que efetua quanto aquele que recebe a transação são identificados" (Andrade \& Najberg, 1997, p.1846). Segundo estes autores, a MCS procura representar a totalidade dos fluxos de renda em uma economia para determinado período de tempo. Assim, consegue-se coerência nas definições de excedente delas obtidas. Esta foi uma das principais razões para a escolha deste tipo de abordagem no presente estudo.

É possível perceber que há relação entre a evolução da percepção de como a agricultura se insere no contexto da economia, considerando sua interdependência com os outros setores, e a evolução dos métodos de estimação que consideram explicitamente essas relações intersetoriais. As definições propostas por Karshenas (1994), no entanto, são semelhantes e confirmam a validade de outras como por exemplo as de Ohkawa \& Rosovsky (1961), Teubal (1971, 1975) e Gutierrez \& Barbero (1988). 


\section{METODOLOGIA}

Acredita-se que, com os procedimentos descritos neste Capítulo, será possível obter uma estimativa do excedente do setor agrícola no Brasil no período de 1980 a 1998. Obviamente não se espera obter uma medida exata de tal fluxo. Interessa, no entanto, assim como em outros trabalhos (Teubal, 1971; Karshenas, 1994; Evangelista, 1997), conhecer a tendência dessa importante variável do processo de crescimento econômico.

Conforme destacado no Capítulo anterior, Evangelista (1997) utilizou definição baseada na Matriz de Contabilidade Social (MCS) proposta por Karshenas (1994). Para tanto, trabalhou com variáveis relativas à seguinte expressão:

$R=\left(F_{a}-Y_{f}\right)-\left(K_{f}^{g}-K_{g^{\prime}}^{f}\right)-\left(K_{f}^{o}-K_{o}^{f}\right)-\left(T_{f}^{g}-T_{g}^{f}\right)-\left(T_{f}^{o}-T_{o}^{f}\right)$

Esta expressão corresponde à forma algébrica financeira do excedente gerado no setor agrícola. No entanto, em se tratando do Brasil como um todo e devido à disponibilidade de informações no Sistema de Contas Nacionais (SCN), utiliza-se no presente estudo a expressão:

$R=F_{a}-\left(C_{a}^{f}+C_{n}^{f}\right)-\left(I_{a}^{f}+I_{n}^{f}\right)$
(a)
(b)
(c)

Também derivada da MCS de Karshenas (1994), e semelhante àquelas utilizadas por Ohkawa \& Rosovsky (1961), Colomé (1978), Gutierrez \& Barbero (1988), onde:

(a) = valor adicionado pelo setor agrícola; 
(b) = consumo total de bens e serviços finais, tanto de produtos agrícolas como de nãoagrícolas, pelas famílias do setor agrícola; e,

(c) = investimento total no setor agrícola em bens do próprio setor ou do setor nãoagrícola.

Outra conveniência dessa definição é que permite o cálculo direto do excedente líquido do setor agrícola $\left(\mathrm{NS}_{\mathrm{a}}\right)$ definido no Capítulo anterior, expressão (3.12.12), ou seja, a diferença entre os termos (a) e (b) da expressão (3.12.1') acima. É importante destacar que no presente estudo, assim como em Evangelista (1997), não foi montada a MCS para o Brasil. A mesma foi utilizada somente para a definição do excedente financeiro.

O que se trata como setor agrícola corresponde, daqui para frente, ao setor Agropecuária das Matrizes de Recursos e Usos do Sistema de Contas Nacionais (SCN). Outra definição necessária é a de famílias do setor agrícola, neste trabalho aquelas famílias dedicadas a atividades agropecuárias, tal como aparece na PNAD, independente da situação do domicílio. Como ilustração tem-se que, segundo a PNAD de 1997, a PEA agrícola representava $17,5 \%$ da PEA total. Além disso, 61,3\% da PEA agrícola tinha domicílio rural e 31,7\% domicílio urbano. Em valores absolutos, 7,06 e 3,27 milhões de pessoas, respectivamente. ${ }^{42}$

A explicação para tal definição pode ser obtida através dos fluxos das Matrizes de Contabilidade Social. As atividades utilizam fatores de produção, que são "remunerados". É o caso, por exemplo, do valor adicionado gerado pelas atividades produtivas agrícolas e recebido pela mão-de-obra e pelo capital agrícola e não-agrícola $\left(\mathrm{VL}_{\mathrm{a}}{ }^{\mathrm{a}}, \mathrm{VL}_{\mathrm{n}}{ }^{\mathrm{a}}, \mathrm{VK}_{\mathrm{a}}{ }^{\mathrm{a}}, \mathrm{VK}_{\mathrm{n}}{ }^{\mathrm{a}}\right.$, respectivamente, na matriz de Morrison \& Thorbecke, 1990). Esses valores são repassados aos detentores dos fatores de produção, ou seja, às famílias agrícolas e não-agrícolas. Como exemplo, tem-se os rendimentos da mão-de-obra agrícola recebidos pelas famílias dos setores agrícola e não-agrícola $\left(\mathrm{L}_{\mathrm{a}}{ }^{\mathrm{a}}, \mathrm{L}_{\mathrm{n}}{ }^{\mathrm{a}}\right.$,

${ }^{42}$ Segundo informações cedidas pelo Professor Rodolfo Hoffmann. 
respectivamente, na matriz de Morrison \& Thorbecke, 1990). Assim, há necessidade de subtrair do valor adicionado nas atividades agrícolas o consumo e os investimentos realizados pelas famílias que "atuaram" na sua geração.

O valor adicionado pelo setor agrícola é obtido diretamente do SCN. Segundo o IBGE (1997c, p.11), o SCN baseia-se em recomendação de amplitude mundial, o System of National Accounting - SNA 93. O SNA define um sistema de contas como "um conjunto coerente, consistente e integrado de contas macroeconômicas, de contas de patrimônio e de quadros, baseado em conceitos, definições, classificações e normas contabilistas internacionalmente aceitas". Com isso é possível superar a grande discrepância entre metodologias, que não permitia comparações internacionais. Com relação ao consumo das famílias agrícolas e ao investimento no setor agrícola, há necessidade de elaborar pressuposições para se obter estimativas destes valores, uma vez que o SCN traz a origem dos bens destinados a estas finalidades, mas não especifica os agentes destinatários.

\subsection{O consumo das famílias agrícolas (Cfa)}

Face às considerações acima, o consumo das famílias do setor agrícola é tomado, então, como uma proporção do consumo total da famílias. Conforme visto anteriormente, Mundle \& Ohkawa (1979) apresentam três alternativas para a obtenção do consumo do setor agrícola a partir do consumo do setor rural (dado de que dispunham). Como aparentemente não existe consenso, poderiam ser aventadas aqui duas alternativas. Uma alternativa, levantada por Mundle \& Ohkawa (1979), é aquela também utilizada por Gutierrez \& Barbero (1988). A proporção do consumo total que é destinada ao setor agrícola é obtida da seguinte forma: toma-se o consumo total, dividindo-o pela população total do país, obtendo o consumo per capita. Este é, então, 
multiplicado pela população agrícola ${ }^{43}$ (todas as pessoas que dependem da agricultura). Compreende todas as pessoas ocupadas na agricultura e seus dependentes não ativos (FAO, 1998). De acordo com Gutierrez \& Barbero, tal metodologia não determina o consumo real, mas sim o que seria consumido se a população existente no setor agropecuário tivesse os mesmos padrões de consumo da população total do país.

$\mathrm{Na}$ realidade, a hipótese contida em tal procedimento é a de que a capacidade/possibilidade de consumo médio das famílias agrícolas é o mesmo das famílias não-agrícolas. É preciso, portanto, esclarecer o que se entende por capacidade (um aspecto quantitativo) e padrão de consumo (um aspecto qualitativo). Quanto à questão de a capacidade de consumo ser a mesma para as famílias dos setores agrícola e não-agrícola, seria difícil definir especificamente qual o grau de diferenciação entre esses setores. O rendimento médio mensal das pessoas ligadas às atividades agrícolas, levantado pela PNAD de 1997 , era de $\mathrm{R} \$ 268,31$, enquanto o das pessoas ligadas a atividades não-agrícolas era de $\mathrm{R} \$ 592,89 .{ }^{44}$ Usando o salário mínimo (SM) médio de $\mathrm{R} \$$ 117,30 de 1997 (Conjuntura Econômica), esses valores correspondem, respectivamente, a 2,3 SM e 5,1 SM. Sabe-se que a proporção do rendimento destinada ao consumo é maior nas faixas de renda inferiores. Tomando as proporções da renda gasta em consumo da Pesquisa de Orçamentos Familiares de 1995-96 (IBGE, 1999d), tem-se que as mesmas seriam de aproximadamente $90 \%$ no primeiro caso e $85 \%$ no segundo (considerando até 5 SM a proporção seria de $88 \%$ no segundo caso). Percebe-se que o procedimento adotado por Gutierrez \& Barbero (1988), ao assumir que o padrão de consumo dos setores agrícola e não-agrícola é o mesmo, está associado a uma hipótese muito forte (restritiva), pois a proporção média da renda destinada ao consumo é semelhante, mas a renda média não o é.

Outra alternativa seria adotar a proporção entre consumo das famílias agrícolas e consumo total como sendo a mesma entre a renda das famílias agrícola em relação à

\footnotetext{
${ }^{43}$ Obtida considerando a estreita relação entre PEA Agrícola/PEA Total e População Agrícola/População Total (FAO, 1999).

${ }^{44}$ Informações cedidas pelo Professor Rodolfo Hoffmann.
} 
renda total das famílias. Utilizar-se-ia, portanto, a proporção de valor adicionado relacionado à atividade agrícola em relação ao valor adicionado total da economia, o que é razoável em função da definição de família agrícola. Esta foi a opção utilizada por Mundle \& Ohkawa (1979). Neste caso, a hipótese é de que o padrão qualitativo de consumo entre os setores agrícola e não-agrícola é o mesmo, além de considerar a diferença de renda nos dois setores. ${ }^{45}$ Essa questão do padrão semelhante é mais aceitável, principalmente em função do grau de urbanização atingido pela população brasileira. Quanto ao fenômeno da urbanização, o mesmo pode ser visualizado de diferentes formas, destacadas por Alves \& Peres (1999). A primeira é o próprio sentido de proporção de pessoas vivendo nas áreas urbanas, 78,36\% da população total em 1996 (IBGE, 2000), proporção essa é maior no Centro-Sul. A segunda é levantada por Silva et al. (1999): o aumento das atividades tipicamente urbanas no meio rural. Finalmente, e diretamente ligada ao tema em análise aparece aquela atribuída a Pereira ${ }^{46}$, citado por Alves (1996), ou seja, a urbanização consiste na adesão e efetivação de um modo de vida urbano pelas populações não citadinas, o que acarreta a expansão quantitativa e qualitativa das necessidades de consumo material e não material para além das cidades, fazendo com que haja uma homogeneização da sociedade quanto à adesão a padrões de vida mais elevados.

Realmente, testes preliminares mostraram uma esperada superestimação do consumo no caso do uso da metodologia utilizada por Gutierrez \& Barbero (1988): os valores de consumo foram maiores que o próprio valor adicionado pelo setor agrícola para todos os anos do período analisado. ${ }^{47}$ Optou-se, no presente estudo, por utilizar o mesmo procedimento de Mundle \& Ohkawa (1979). Considera-se que neste caso há uma melhor aproximação do valor do consumo das famílias agrícolas, bem como a adoção de uma hipótese menos restritiva. O consumo das famílias agrícolas (Cfa) fica sendo definido, então, por:

\footnotetext{
${ }^{45}$ É fácil perceber que neste caso a relação entre consumo e valor adicionado é igual para os dois setores. ${ }^{46}$ PEREIRA, L. (Org.) Urbanização e subdesenvolvimento. 2.ed. Rio de Janeiro: Zahar, 1972. 189p.

${ }^{47}$ Mesmo superestimando o consumo, tal medida do consumo das famílias do setor agrícola tem tendência decrescente, pois a proporção de famílias agrícolas diminui em relação ao total de famílias. Isto faz com que as estimativas de excedente líquido, mesmo que negativas, tenham tendência crescente.
} 
$C f a=(V A a / V A t) * C t$

Onde:

- Ct: consumo total de bens finais pelas famílias;

- VAt: valor adicionado total da economia; e,

- VAa: valor adicionado pelo setor agrícola.

O valor do consumo total a preços básicos foi obtido diretamente das Matrizes de Insumo-Produto de cada ano para o período 1980 a 1996. Para 1997 e 1998 foi necessário estimá-lo com base nos valores a preços de consumidor. Os valores a preços básicos desses dois anos foram obtidos a partir da média da relação entre consumo total a preços de consumidor e consumo total a preços básicos do período 1990-1996.

\subsection{Os investimentos no setor agrícola (Ia)}

Com relação aos investimentos no setor agrícola, também há necessidade de usar estimativas para a série 1980 a 1998, uma vez que tal informação existe somente para 1980, na Matriz de Insumo-Produto e para 1980, 1985 e 1995/96, nos Censos Agropecuários. Neste caso, tal estimação poderia ser feita de diferentes formas. Uma delas seria utilizar o montante de crédito rural utilizado para investimentos. No entanto, tal valor não capta os investimentos governamentais no setor agrícola, tampouco aqueles

realizados com recursos dos próprios produtores. Com relação a este aspecto tem-se o estudo de Liebhardt (1988) que tentou retratar os efeitos das mudanças no crédito rural no ano-safra 1984/85, período de substancial elevação das taxas de juros no crédito oficial. Segundo o autor, os empréstimos formais seriam usados como complementação de recursos, por um lado e, por outro, permitiria liberação de recursos próprio para outros fins. 
Em pesquisa de campo com 306 agricultores em sistemas de produção representativos da região Centro-Sul, Liebhardt relata que em $45 \%$ das observações foram tomados empréstimos para investimento, percentual inferior ao total de investimentos efetivamente realizados na amostra. O autor considera que parte dos investimentos foi viabilizada com recursos próprios ou com uma composição de recursos próprios e/ou financiamentos de custeio. Nas oito subamostras estudadas, os produtores realizaram investimentos nas propriedades, não financiados ou somente parcialmente financiados pelo Sistema Nacional de Crédito Rural. O autor não considera em seu trabalho que pode ter havido crédito de fontes informais.

Não se dispõe de informações sobre a relação entre o montante de crédito e o valor dos investimentos efetivamente realizados nas fazendas, a não ser para os anos de 1980, 1985 e 1995-1996. Os Censos Agropecuários desses anos revelam relações entre empréstimos para investimento e investimento total de $8,25 \%, 4,17 \%$ e $12,13 \%$, respectivamente (IBGE, 1983,1984; IBGE, 1991; IBGE, 1998a), mostrando fraca relação. Dada a instabilidade da economia brasileira no período analisado, qualquer tipo de extrapolação ou interpolação implicaria pressuposições altamente restritivas. Resolveu-se, então, partir para outro tipo de abordagem, idealizada a partir de estudos sobre a evolução do estoque de capital da agricultura no Brasil. A partir daí derivaram três estimativas para os investimentos no setor agrícola. O que se pretende, ao usar mais de uma estimativa, é ter idéia de como se comporta o excedente financeiro do setor agrícola em diferentes situações, uma vez que não existe consenso sobre o montante de investimento realizado no setor ano a ano. Essa diversidade de opções segue o procedimento adotado por Barros (1999), autor que também relata a falta de uma opção consensual para estimar o estoque de tratores no Brasil. As três opções de estimação são descritas a seguir. 


\title{
4.2.1 Série com base na variação do estoque de tratores e o investimento da Matriz de Insumo-Produto de 1980 (Ia1)
}

Estudos de Barros (1999) e de Bonelli \& Fonseca (1998) tomam valores relativos à mecanização como proxies da evolução do estoque de capital do setor agrícola. Estes últimos utilizam a variação no estoque de máquinas e implementos agrícolas como aproximação para a variação no estoque de capital do setor agropecuário (lavouras). Barros trabalha com o investimento em tratores e, nesse sentido, vale a seguinte referência:

\begin{abstract}
"o presente trabalho pretende investigar o processo de formação de capital e evolução da produtividade na agricultura brasileira... . A avaliação partirá da construção de formas alternativas de mensuração do estoque de tratores agrícolas no Brasil. O comportamento dos investimentos em tratores servirá como proxy das tendências de formação de capital no setor. ${ }^{48}$ Sabe-se, de antemão, que esse procedimento é uma aproximação imprecisa do comportamento do estoque de capital agregado. Ocorre, contudo, que o mercado de tratores é, dentre os componentes do estoque de capital físico, aquele que permite uma inferência empírica mais profunda, em razão da confiabilidade e periodicidade dos dados disponíveis" (Barros, 1999, p.1)
\end{abstract}

Este autor construiu séries de valor monetário do estoque, estoque em número de tratores e em número de cavalos vapor (potência). Como as séries apresentam evolução semelhante, optou-se pela de número de tratores. O valor para 1998 foi obtido diretamente de Barros, uma vez que no seu estudo as séries chegavam até 1997.

\footnotetext{
${ }^{48}$ Grifo nosso.
} 
Tabela 4. Estoque e venda de tratores de roda no Brasil, de 1980 a 1998 (unidades).

Ano Estoque de tratores de roda

Venda interna de tratores nacionais de roda

\begin{tabular}{lll}
\hline 1980 & 555124 & 50195 \\
1985 & 663487 & 40736 \\
1990 & 801914 & 21241 \\
1991 & 805559 & 13495 \\
1992 & 800949 & 11727 \\
1993 & 800766 & 21396 \\
1994 & 809941 & 38491 \\
1995 & 788574 & 17584 \\
1996 & 753037 & 10291 \\
1997 & 711661 & 15731 \\
1998 & 672718 & 18158 \\
\hline
\end{tabular}

Fonte: estoque de 1980 a 1997, Barros (1999); estoque de 1998, Alexandre L. Mendonça de Barros — comunicação pessoal; vendas, ANFAVEA (1999).

Nota: o número de tratores importados não foi incluído por falta de dados para todo o período. Além disso, provavelmente não haveria mudança na tendência pois a proporção de importados em relação aos nacionais é pequena, por exemplo 2,02\% e 2,86\% em 1997 e 1998, respectivamente, segundo ANFAVEA (1999).

Ora, se a variação no estoque de tratores é utilizada como proxy da a variação do estoque de capital e se existe um valor de referência, é possível, ciente das restrições já destacadas, construir uma série aproximada do que tenha sido aquela relativa aos investimentos no setor agrícola. Para tanto, utiliza-se o investimento no ano de 1980 como o valor base da série. O valor dos investimentos nos anos seguintes guardam com o mesmo a mesma relação que o estoque de tratores dos respectivos anos guardam com o estoque de tratores do ano de 1980. Tal série de investimentos designa-se, daqui para frente, por investimento Ia1.

Constatação interessante levou à construção de outras duas séries para os investimentos no setor agrícola (Ia): a de que existe uma relação aproximada entre as variações nos investimentos verificados nos Censos Agropecuários e a variação nas 
vendas internas de tratores nacionais de roda. Tal relação é mostrada na Tabela 5 e na Figura 2. Assume-se que os investimentos relatados no Censo de 1995-96 foram realizados no ano de 1995.

Tabela 5. Valores e variações dos investimentos, vendas de tratores e estoque de tratores, 1980, 1985 e 1995.

\begin{tabular}{lccc}
\hline & 1980 & 1985 & 1995 \\
\hline Investimentos (R\$ 1000 de 1998) & $36.989,78$ & $30.464,38$ & $9.618,13$ \\
Venda de tratores (unidades) & 50.195 & 40.736 & 17.584 \\
Estoque de tratores (unidades) & 555.124 & 663.487 & 788.574 \\
Variação nos investimentos $^{\mathrm{a}}(\%)$ & - & $-17,64$ & $-68,43$ \\
Variação nas vendas de tratores $^{\mathrm{a}}(\%)$ & - & $-18,84$ & $-56,83$ \\
Variação no estoque de tratores $^{\mathrm{a}}(\%)$ & - & 19,52 & 18,85 \\
\hline
\end{tabular}

Fonte: investimentos, Censos Agropecuários; vendas de tratores, ANFAVEA (1999); estoque de tratores, Barros (1999). Elaboração do autor.

${ }^{a}$ Em relação ao ano anterior.

Ferreira Filho \& Costa (1999) destacam que houve queda na venda de tratores de roda a partir do início da década de 80 . No entanto, na década de 90 não há tendência definida, conforme pode ser observado na Tabela 4. Verifica-se, na Tabela 5, que há maior relação entre vendas de tratores e investimentos do que entre variações no estoque de tratores e nos investimentos. Com base nesta observação é que optou-se por construir as séries baseadas na variação das vendas de tratores, descritas a seguir.

Outro fato importante para o qual Ferreira Filho \& Costa (1999) chamam a atenção é que o número de tratores vendidos pode dar uma idéia enganosa do dispêndio efetivo em tratores, pois é preciso considerar a potência dos tratores. ${ }^{49}$ Os autores verificaram um aumento, entre 1970 e 1996, da venda de tratores de potência mais elevada (de 50 c.v. a 199 c.v.). Com relação à década de 90, tem-se que entre os períodos 1990-94 e 1995-96 houve aumento da proporção de tratores na faixa de 50 a 99 c.v. em relação à faixa de 100 a 199 c.v. Então, um mesmo número de tratores no

\footnotetext{
${ }^{49}$ Griliches (1960) já chamava atenção para a questão de como os aspectos qualitativos afetam os preços dos bens.
} 
segundo período pode representar um desembolso relativamente menor. O contrário ocorre se forem considerados os valores entre a década de 80 e o período 1990-94.

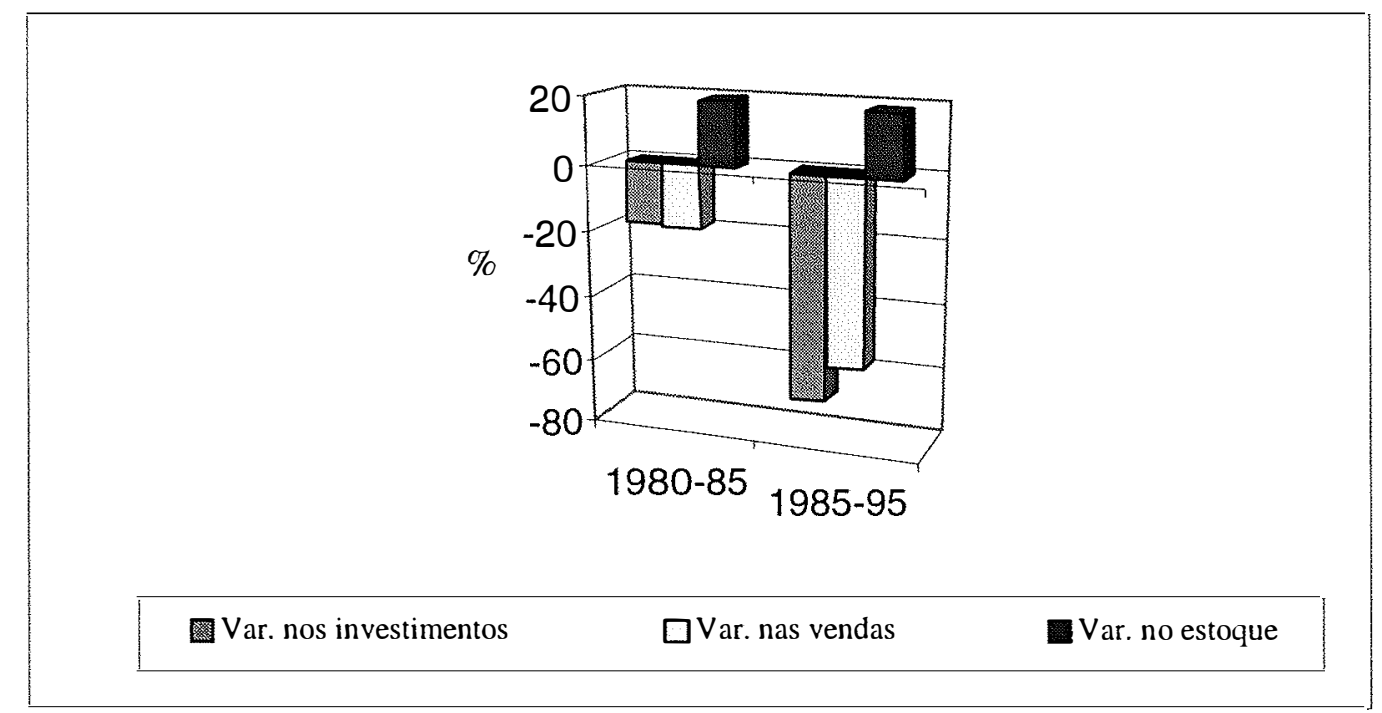

Figura 2. Variações nos investimentos, nas vendas de tratores e estoque de tratores de 1980 a 1985 e de 1985 a 1995.

Fonte: elaboração do autor.

\subsubsection{Série com base na variação das vendas de tratores e o investimento da Matriz de Insumo-Produto de 1980 (Ia2)}

Esta série permite a comparação entre uma série construída com base na variação do estoque de tratores (investimento Ia1) e outra com base na variação das vendas (investimento Ia2), uma vez que ambas partem do investimento da Matriz de InsumoProduto de 1980. O valor dos investimentos de 1985 em diante guardam com o valor do investimento em 1980 a mesma relação que as vendas de tratores dos respectivos anos guardam com a venda de tratores do ano de 1980. 


\subsubsection{Série com base na variação das vendas de tratores e o investimento dos Censos Agropecuários (Ia3)}

Uma vez que existe correlação entre as variações dos investimentos dos Censos e das vendas de tratores, uma terceira série para investimentos foi construída. Neste caso, os valores de Ia3 para 1980, 1985 e 1995 correspondem àqueles relatados nos três últimos Censos Agropecuários. O valor dos investimentos de 1990 a 1994 e de 1996 a 1998 guardam com o valor dos investimentos em 1995 a mesma relação que as vendas de tratores dos respectivos anos guardam com a venda de tratores de 1995.

Diferentemente do procedimento adotado por Evangelista (1997), não são computados neste trabalho, os subsídios à agricultura. Segundo Nakano ${ }^{50}$, citado por Almeida (1994), os subsídios não implicam aumento de renda para os agricultores, pois acabam sendo transferidos para outros setores via mecanismos de preços. Mas não é por isso que não são considerados. Tal distorção poderia ser captada por uma análise pelo lado financeiro, como fez Evangelista (1997). A razão é que Almeida (1994) relata um aumento nas taxas reais de juros do crédito rural, principalmente a partir de 1987. Isso é reforçado por Goldin \& Rezende (1993) que mostram uma redução nos subsídios ocorrida a partir da década de 80 , sendo que as taxas reais de juros passaram a positivas na década de 90.

Segundo Karshenas (1998), a transferência via termos de troca é apenas um dos mecanismos. Outros tipos, através de contas corrente e de capital de instituições públicas ou privadas, podem amenizar ou reforçar tais transferências. Como exemplos, tem-se que parte da receita tributária pode ser reinvestida no setor agrícola, pode haver subsídios ao setor ou impostos diretos retirando recursos. Há também fatores endógenos. Por exemplo, o crescimento da produtividade total dos fatores na agricultura pode mais que compensar os termos de troca declinantes ao longo do tempo, como aconteceu na agricultura americana de 1910 a 1986 (Tweeten, 1989).

\footnotetext{
${ }^{50}$ NAKANO, Y. O crédito rural num contexto de modernização da economia brasileira. In.: DIFÍCEIS OPÇÕES DO FINANCIAMENTO RURAL, 1, Anais. Belo Horizonte: CNA/FAEMG, 1992.
} 
As transferências visíveis (RV) e invisíveis (RI) e o total das transferências visíveis e invisíveis (RVI) podem ser obtidos a partir da expressão utilizada por Ishikawa (1967a), para o caso de um excedente de importações, ou seja, de entrada de recursos no setor:

$M / P_{m}-E / P_{e}=R / P_{m}+E / P_{e}\left[\left(P_{e} / P_{m}\right)-1\right]$

Ou, a partir da seguinte expressão, também indicada por Ishikawa (1967a), para o caso de um excedente de exportações, equivalente à expressão (3.12.11) e que é a utilizada no presente trabalho:

$E / P_{e}-M / P_{m}=R / P_{e}+M / P_{m}\left[\left(P_{m} / P_{e}\right)-l\right]$

Onde:

$R=M-E$

$\mathrm{M}=$ valor da importações, neste caso a soma do consumo das famílias do setor agrícola e os investimentos no setor agrícola;

$\mathrm{E}=$ valor das exportações; neste caso o valor adicionado pelo setor agrícola;

$\mathrm{P}_{\mathrm{m}}=$ índice de preços de importação, neste caso o Índice de Preços Pagos (IPP) pelos produtores rurais;

$\mathrm{P}_{\mathrm{e}}=$ índice de preços de exportação, neste caso o Índice de Preços Recebidos (IPR) pelos produtores rurais;

$R / P_{e}=R V$

$M / P_{m}\left[\left(P_{d} / P_{m}\right)-1\right]=R I ; \mathrm{e}$,

$R V+R I=R V I$. 
De acordo com Evangelista (1997), uma modificação na apuração dos índices (IPR e IPP) em 1987, produziu séries não comparáveis entre si, obrigando-o a dividir seus resultados em dois subperíodos (lembrando que estudou o período 1966 a 1993). No presente estudo, cujo foco principal é a década de 90 , optou-se por calcular as transferências visíveis e invisíveis apenas nesta década.

Os resultados são apresentados em três formatos. O primeiro apresenta a série de resultados dos excedentes em US\$ de 1998. O segundo traz a evolução dos excedentes como proporções do valor adicionado pelo setor agrícola e o valor adicionado total com o propósito de eliminar problemas de deflacionamento - e o terceiro apresenta os resultados como US\$ de 1998 considerando as transferências em função de mudanças nos termos de troca. Adicionalmente, os valores a preços constantes, em $\mathrm{R} \$$ de 1998 , são apresentados nos Anexos.

\subsection{Definição das variáveis}

Neste item, são definidas as principais variáveis em análise. São as que seguem.

- Ct: consumo total de bens e serviços finais pelas famílias;

- Cfa: consumo de bens e serviços finais pelas famílias agrícolas, tanto de produtos agrícolas como não-agrícolas;

- VAt: valor adicionado total da economia;

- VAn: valor adicionado pelo setor não-agrícola;

- VAa: valor adicionado pelo setor agrícola;

- Ia1: investimentos no setor agrícola, realizados tanto pelo setor público quanto privado, com base na Matriz de Insumo-Produto de 1980 cuja variação anual segue a variação do estoque de tratores; 
- Ia2: investimentos no setor agrícola, realizados tanto pelo setor público quanto privado, com base na Matriz de Insumo-Produto de 1980 cuja variação anual segue a variação das vendas de tratores;

- Ia3: investimentos no setor agrícola, realizados tanto pelo setor público quanto privado, dos Censos Agropecuários, cuja variação anual segue a variação das vendas de tratores;

- NSa: excedente agrícola líquido,

- Ri: excedente financeiro do setor agrícola, calculado com base no NSa e nas estimativas de investimentos no setor agrícola, Iai, $\mathrm{i}=1 . .3$;

- RIi: transferências invisíveis referentes ao $\mathrm{Ri}, \mathrm{i}=1 . .3$;

- RVi: transferências visíveis referentes ao $\mathrm{Ri}, \mathrm{i}=1 . .3$;

- RVIi: soma das transferências visíveis e invisíveis referentes ao Ri, i=1..3.

As estatísticas das contas nacionais são utilizadas a preços básicos. A adoção de valoração a preços "aproximadamente básicos" objetiva proporcionar maior homogeneidade aos dados, "uma vez que estão excluídos os impostos, subsídios e margens de distribuição incidentes sobre os produtos e que estão sujeitas a alterações não relacionadas com o processo de produção" (IBGE, 1989, p.15). O dados básicos foram obtidos de IBGE (1984, 1991, 1988, 1989, 1997b, 1998a, 1998b, 1999b, 1999e). É necessário destacar que os dados do Sistema de Contas Nacionais para 1998 são preliminares e para 1997 são semi-definitivos (IBGE, 1998b; IBGE, 1999e). 


\section{RESULTADOS E INTERPRETAÇÃO}

A pesquisa procura em primeiro plano analisar a evolução do excedente líquido do setor agrícola $(\mathrm{NSa})$, das diferentes versões do excedente financeiro $(\mathrm{R})$ inclusive considerando as transferências em função de mudanças nos termos de troca no período como um todo, enfatizando porém os resultados da década de 90 . As análises dos investimentos e dos excedentes são finalizadas procurando avaliar possíveis relações entre os resultados e o contexto macroeconômico. Primeiramente são apresentadas as estimativas do consumo no setor agrícola ( $\mathrm{Cfa}$ ) e das diferentes versões para os investimentos no setor agrícola (Ia) e, posteriormente, os resultados referentes ao excedente.

\subsection{O consumo das famílias agrícolas (Cfa)}

A Tabela 6 Figura 3 e a mostram a evolução do valor adicionado do setor agrícola (VAa) e do consumo das famílias agrícolas (Cfa) no período analisado. Observa-se que os valores de consumo acompanham os de valor adicionado. Isto está de acordo com o fato conhecido, citado por Ferreira Filho (1998), de relativa estabilidade da função consumo. Tais dados confirmam também a possível validade da estimativa adotada para o consumo no setor agrícola, uma vez que, tendo assumido padrão qualitativo de consumo semelhante para o setor agrícola e a economia como um todo, é plausível esperar que também no setor agrícola o consumo acompanhe a evolução da renda. 


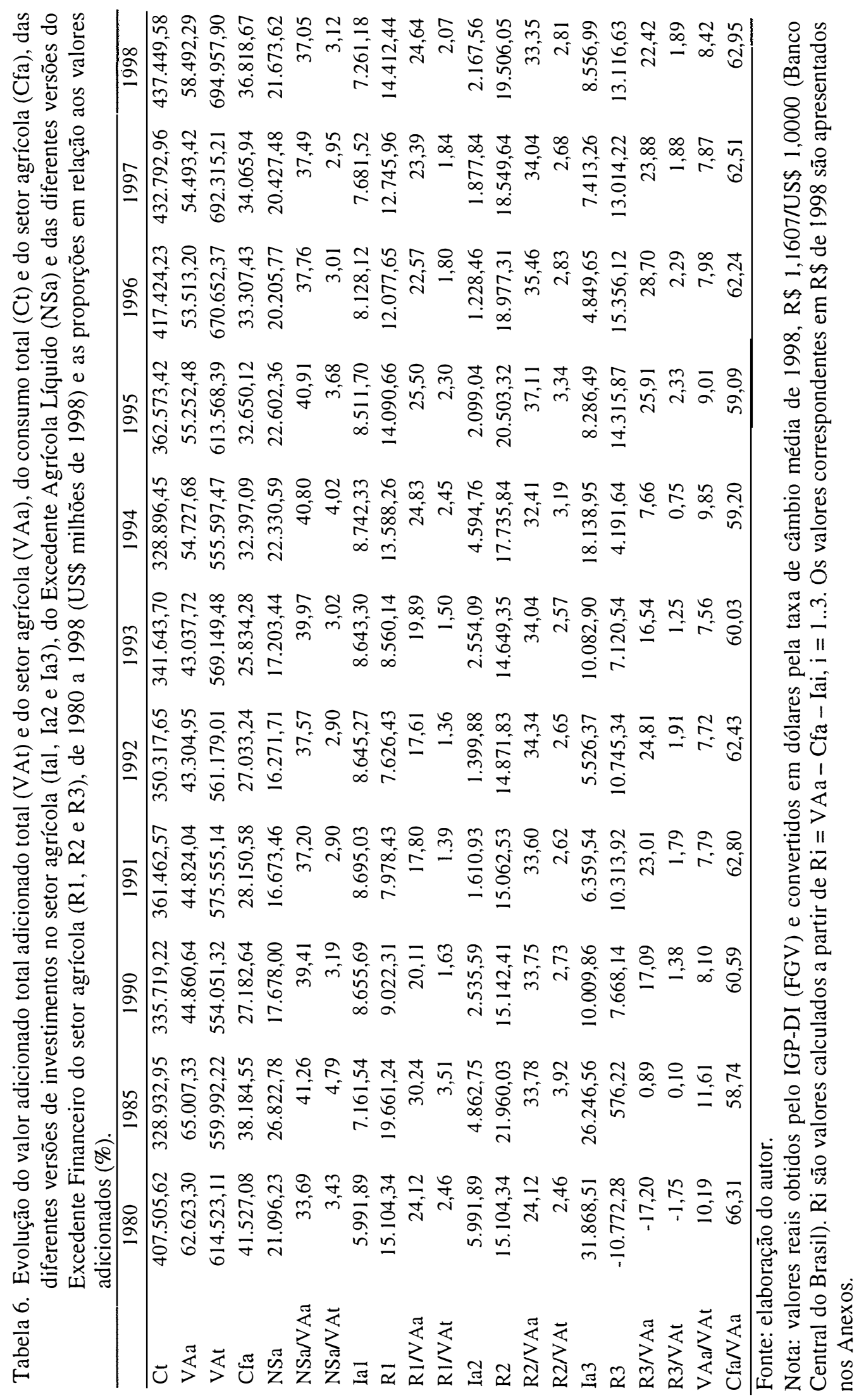




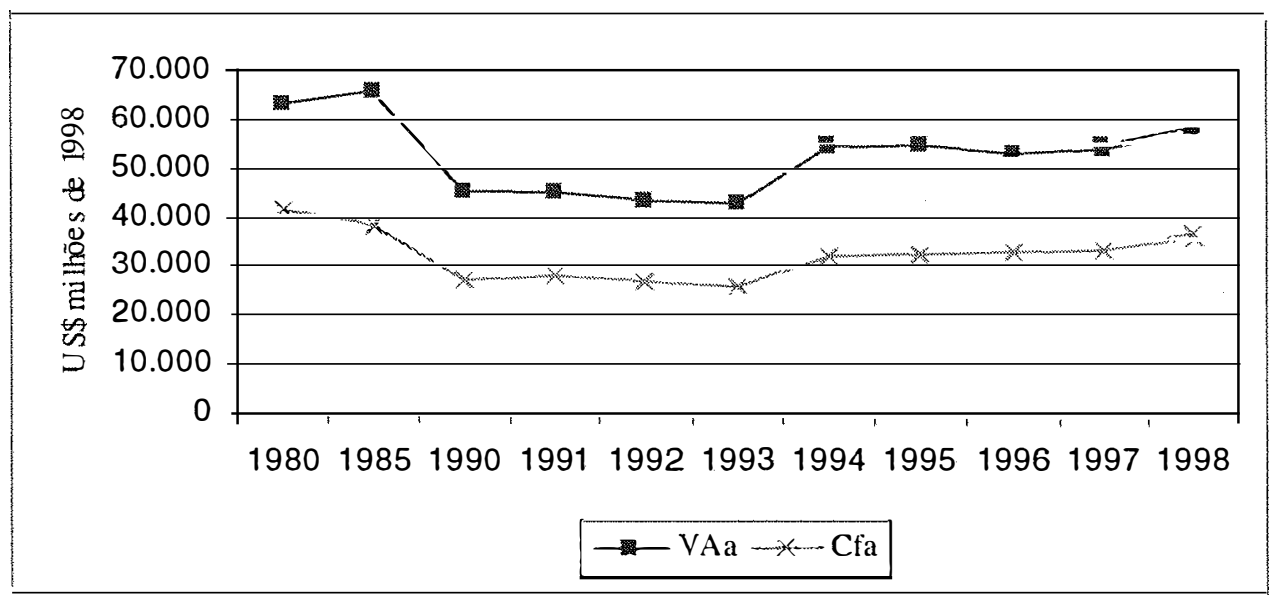

Figura 3. Evolução do valor adicionado do setor agrícola (VAa) e do consumo da famílias agrícolas (Cfa) de 1980 a 1998 (US\$ milhões de 1998).

Fonte: Elaboração do autor.

\subsection{Os investimentos no setor agrícola}

São mostradas nesta seção as séries estimadas de investimentos no setor, obtidas segundo os procedimentos descritos no Capítulo anterior. Essas séries, investimento Ia1 (investimento obtido com base na Matriz de Insumo-Produto de 1980 e variação igual à do estoque de tratores), Ia2 (investimento obtido com base na Matriz de Insumo-Produto de 1980 e variação igual à de vendas de tratores) e Ia3 (investimento obtido com base nos Censos Agropecuários e variação igual à de vendas de tratores) dão origem a três versões para o excedente financeiro (R): excedente financeiro R1, R2 e R3 constantes da Tabela 6. A evolução dos diferentes cenários de investimento são apresentados na Tabela 7 e na Figura 4. 
Tabela 7. Evolução do investimento Ia1, Ia2 e Ia3 de 1980 a 1998 (US\$ milhões de 1998).

\begin{tabular}{cccc}
\hline Ano & Ia1 & Ia2 & Ia3 \\
\hline 1980 & $5.991,89$ & $5.991,89$ & $31.868,51$ \\
1985 & $7.161,54$ & $4.862,75$ & $26.246,56$ \\
1990 & $8.655,69$ & $2.535,59$ & $10.009,86$ \\
1991 & $8.695,03$ & $1.610,93$ & $6.359,54$ \\
1992 & $8.645,27$ & $1.399,88$ & $5.526,37$ \\
1993 & $8.643,30$ & $2.554,09$ & $10.082,90$ \\
1994 & $8.742,33$ & $4.594,76$ & $18.138,95$ \\
1995 & $8.511,70$ & $2.099,04$ & $8.286,49$ \\
1996 & $8.128,12$ & $1.228,46$ & $4.849,65$ \\
1997 & $7.681,52$ & $1.877,84$ & $7.413,26$ \\
1998 & $7.261,18$ & $2.167,56$ & $8.556,99$ \\
\hline \hline
\end{tabular}

Fonte: elaboração do autor.

$\mathrm{Na}$ década de 80, o investimento Ia3 foi bem superior a Ial e a Ia2, mas para os anos 90 há maior convergência, em termos de magnitude, principalmente entre os investimentos Ia3 e Ia1. As estimativas de Ia 2 e Ia3 evoluem de maneira semelhante. Isto poderia ser tido como óbvio, mas não o é, pois os valores de Ia3 de 1980, 1985 e 1995 referem-se a dados oficiais, e não a estimativas, confirmando a venda de tratores como boa proxy para a evolução dos investimentos no setor agrícola. Isto não deixa de ser verdade mesmo quando se considera a análise de Ferreira Filho \& Costa (1999). Segundo eles, a redução na venda de tratores pode estar associada à maior eficiência no uso (ou sucateamento da frota). Tal afirmação vale também para os demais componentes do estoque de capital do setor agrícola, ou seja, os fatores que influenciam a eficiência de uso de tratores e máquinas influem também na eficiência do uso dos outros insumos. 


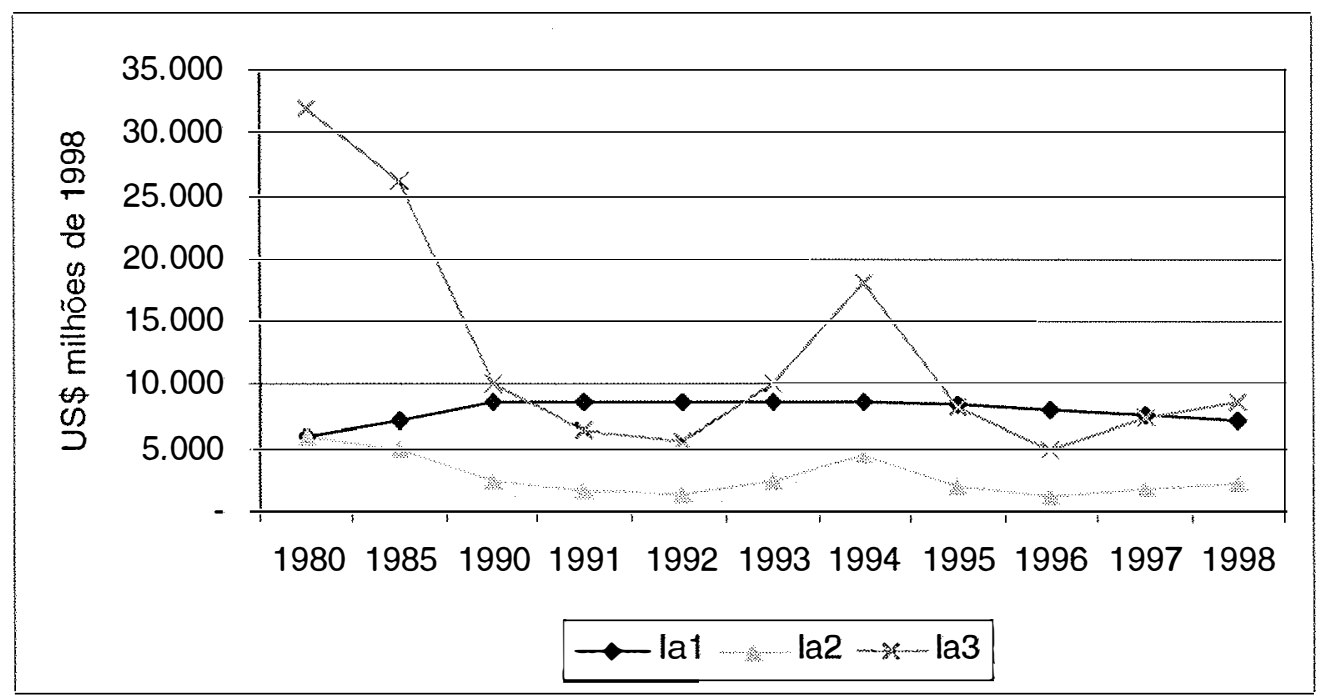

Figura 4. Evolução das estimativas de investimento no setor agrícola, Ia 1, Ia2 e Ia3, de 1980 a 1998 (US\$ milhões de 1998).

Fonte: elaboração do autor.

As estimativas de investimentos Ia2 e Ia3 apresentam maior aderência em relação ao contexto econômico do período analisado (fato, aliás, esperado, da observação da Tabela 5 e Figura 2 do Capítulo 4). O valor alto do investimento Ia3 em 1980 está de acordo com Rezende (1989) ao afirmar que o crédito rural e o subsídio implícito na taxa de juros, por exemplo, foram mantidos em níveis dos mais altos no período 1979 a 1982. Pinheiro (1995) relata contração brusca nas taxas de investimento de 1980 até 1992, com recuperação em 1993 e 1994. A melhoria no lado real da economia coincidiu, em 1994, com a queda da inflação no segundo semestre. Segundo este autor, neste ano houve também recuperação do investimento direto externo. Neste mesmo sentido, Rodrigues \& Guilhoto (1998) relatam queda nas taxas de investimento da economia no período 19901992, e recuperação em 1994 e 1995. Ainda, de acordo com IBGE (1997b), a política monetária no início de 1992 foi caracterizada por elevadas taxas de juros, com redução a partir de 1993. A valorização cambial após 1994 associada à abertura econômica provocou déficit na balança comercial que levaram, no início de 1995, à adoção de medidas como aumento dos juros reais, contração da base monetária e redução do crédito no segundo trimestre do ano. 
O ano de 1996 é o único em todo o período no qual há divergência entre o contexto econômico e as estimativas de investimento no setor agrícola que apontam sua redução. Neste ano houve, segundo o IBGE (1997b), flexibilização do crédito e das políticas monetárias. Deve ser levado em conta que as estimativas de investimento são obtidas a partir das variações nas vendas de tratores. De 1995 a 1996 houve redução tanto no crédito rural oficial para investimento quanto na parcela deste destinada à aquisição de tratores (10,3\% do crédito oficial para investimento) segundo a ANFAVEA (1999). Foi a menor proporção em todo o período analisado. Apesar da tendência de aumento na participação dos recursos próprios, a restrição do crédito formal certamente influenciou a queda na venda de tratores e, consequentemente, os valores de investimento do ano.

Em 1997, segundo IBGE (1998b) não foi possível manter a política de redução na taxa de juros iniciada em 1996 e mesmo assim verificou-se crescimento de 3,8\% no PIB. O início de 1998 apresentou sinais de recuperação em relação ao final de 1997, mas houve elevação brusca das taxas de juros no primeiro semestre com redução a partir de novembro e o PIB praticamente não variou (IBGE; 1999e). Assim sendo, é preferível dizer que as informações sobre política monetária não são conclusivas a respeito da aderência ou não das estimativas de investimento no setor agrícola.

\subsection{O excedente líquido do setor agrícola (NSa)}

Pela definição do excedente líquido, torna-se importante avaliar o valor do fluxo per se - lembrando a afirmação de Karshenas (1994) de o excedente líquido contemplar recursos disponibilizados para investimento no próprio setor agrícola e nos outros setores da economia. Por outro lado, está associado ao excedente financeiro (R), sendo então importante na definição de sua evolução. Os resultados da década de 80 são apresentados em separado servindo como referência para a análise central da década de 90. Segundo Rodrigues \& Guilhoto (1998), o final dos anos 80 e a década de 90 
representam período de expressivas mudanças de cenário na economia brasileira, em função da privatização, modernização da economia, abertura econômica e do Plano Real. Assim, devido a essas transformações, a comparação com a década de 80 dever ser vista com cuidado. Os resultados do período 1980-1998 podem ser visualizados na Figura 5 e na Tabela 6. Nesse período, a variação total do excedente líquido foi de 2,8\%. Após instabilidade inicial, na década de 80, verifica-se tendência crescente na década de 90, evolução semelhante à do valor adicionado pelo setor agrícola.

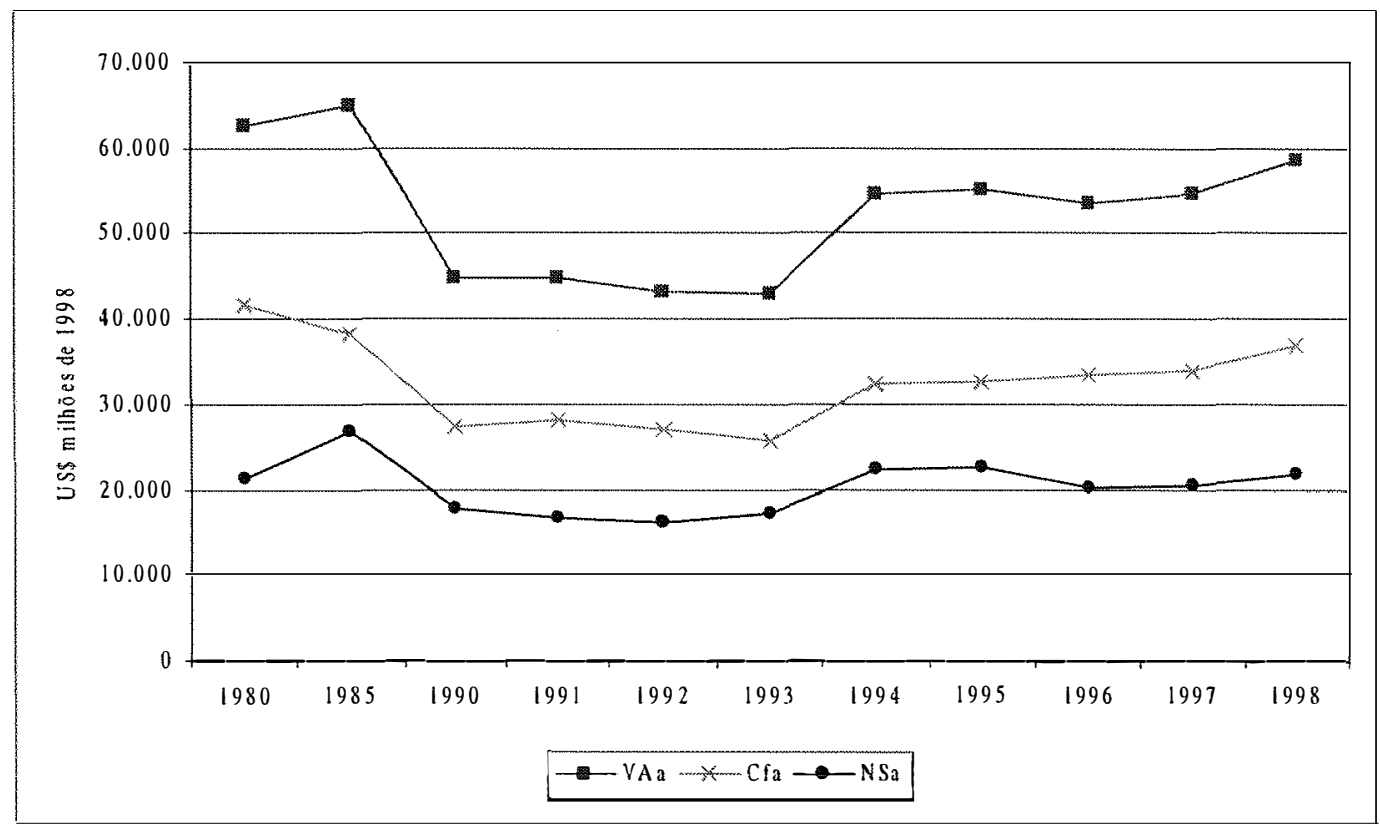

Figura 5. Evolução do valor adicionado do setor agrícola (VAa), consumo das famílias agrícolas (Cfa) e excedente líquido (NSa), de 1980 a 1998 (US\$ milhões de 1998).

Fonte: elaboração do autor.

Na década de 80 há redução ${ }^{51}$ de 16,2\% no excedente líquido (tomando 1990 como último ano da década). O excedente líquido aumenta de 1980 a 1985, seguido de

\footnotetext{
${ }^{51}$ Para os efeitos deste trabalho, os termos "taxa de crescimento" ou "crescimento", referem-se a uma taxa de crescimento estimada por regressão linear simples. Já termos como, por exemplo, "aumentou", "diminuiu" e "variou", geralmente utilizados para períodos menores, referem-se às variações percentuais entre o último e o primeiro ano do período.
} 
redução até 1990. De 1980 a 1985 há aumento no valor adicionado do setor que, associado a uma redução no consumo das famílias agrícolas, provoca aumento no excedente líquido. De 1985 a 1990 há redução tanto no valor adicionado do setor quanto no consumo das famílias agrícolas. Mesmo assim, a queda no valor adicionado foi predominante, levando à redução no excedente líquido.

Comparando os resultados com o desempenho geral da economia, parece haver razoável coerência. Nos anos 80 , o valor adicionado do setor agrícola e o excedente líquido estão de acordo com a variação do produto real da agricultura apresentada pelo Banco Central do Brasil (Boletim do Banco Central). O índice de produção assume os valores 110, 113 e 90 em 1980, 1985 e 1990, respectivamente. As elevações do valor adicionado do setor agrícola e do excedente líquido entre 1980 e 1985 podem ser explicadas por algumas estatísticas do setor. Segundo Goldin \& Rezende (1993), a elevação verificada na relação preços dos insumos/preços dos produtos, por exemplo, provocou queda no uso dos insumos no período 1981-1983. Inversão desse quadro ocorreu em 1984, com a elevação dos preços recebidos pelos produtores em função da alta de preços externos, quebra de safra em 1983 e crise cambial, dificultando importações e também provocando melhoria dos preços mínimos em 1985. Segundo os autores, isso contribuiu para a recuperação do crescimento econômico geral no segundo semestre de 1984. Ainda, segundo Rezende (1989), o setor agrícola viveu fase de euforia no ano agrícola 1984/85, talvez como resultado de boas safras e renda nos anos de 1980, 1981 e 1982, além da disponibilidade de crédito subsidiado.

A redução no valor adicionado do setor agrícola e no seu excedente líquido entre 1985 e 1990, embora de forma menos objetiva que no caso anterior, também parece de acordo com os fatos. Segundo Melo (1992), os preços agrícolas tiveram evolução desfavorável na segunda metade dos anos 80 devido a adversidades no mercado internacional, aceleração inflacionária e sobrevalorização cambial. Tal queda de preços pode ter influenciado negativamente o valor adicionado do setor, como confirmado por Ferreira Filho (1994). Este autor afirma, porém, que a agropecuária pode ter sido 
beneficiada, na década de 80 , com a queda dos preços industriais, de onde provém grande parte de seu consumo intermediário.

$\mathrm{Na}$ década de 90, o excedente líquido apresentou variação de 22,6\%, ou seja, uma taxa de crescimento estatisticamente significativa de 3,61\% a.a. ${ }^{52}$, como ilustrado na Figura 5. O valor adicionado do setor agrícola (VAa) aumentou mais que o valor adicionado total (VAt), ${ }^{53}$ provocando pequeno aumento na relação VAa/VAt (4\%) que, associado à elevação no consumo total $(\mathrm{Ct})$, provocou aumento no consumo das famílias agrícolas (Cfa). Na verdade, com essa pequena variação, a relação VAa/VAt ficou em torno de 0,08 ao longo de toda a década (à exceção de 1994 e 1995 quando passou a 0,10 e 0,09, respectivamente). No geral, não houve tendência crescente ou declinante, e sim certa estabilidade da relação VAa/VAt.

Nos primeiros anos da década há relativa estabilidade do excedente líquido. De fato, e pode ser verificado na Figura 5, o excedente líquido sofre pequena redução no período 1990-1992, registrando aumento a partir de então. O consumo das famílias agrícolas permanece praticamente constante neste período, o que explica a evolução do excedente líquido semelhante à do valor adicionado do setor agrícola, que também sofre pequena redução.

Um segundo subperíodo, de 1992 a 1995, é importante pois apresenta aumento do excedente líquido, que atinge seus valores mais altos na década: pouco mais de US\$ 22 bilhões em 1994 e 1995. Em valores absolutos, o excedente líquido passa de US\$ 16,3 bilhões em 1992 para US $\$ 22,6$ bilhões em 1995, variação de 38,9\%. A maior parte deste aumento, como fica claro na Figura 5, ocorreu entre 1993 e 1994, quando o excedente líquido aumentou 29,8\%, sendo que entre 1994 e 1995 a expansão foi modesta, de $1,2 \%$.

A variação do excedente líquido entre 1993 e 1994 pode ser explicada pelo expressivo aumento do valor adicionado do setor agrícola (que contrasta principalmente

\footnotetext{
52 Adotou-se nível de significância de $10 \%$.

${ }^{53}$ De acordo com o bom desempenho do setor agrícola no período.
} 
com a redução no valor adicionado total), mais que proporcional ao decréscimo no consumo das famílias agrícolas, $27,2 \%$ e $25,4 \%$, respectivamente. O excedente líquido sofre pequena redução no subperíodo 1995-1998, passando de US\$22,2 bilhões para US\$21,7 bilhões. Nota-se redução em 1996, com posterior recuperação até 1998.

A análise de série de tempo incluindo a década de 80 e o início da década de 90 pode sofrer grande influência dos preços na obtenção dos valores reais. Até o momento foram utilizados valores a preços constantes de 1998. Uma forma de eliminar o problema de variação nos preços e ter uma noção da evolução do excedente do setor agrícola é usar as proporções do excedente em relação ao valor adicionado tanto do próprio setor agrícola quanto da economia brasileira.

A Figura 6 e a Tabela 6 mostram a evolução das relações excedente líquido/valor adicionado do setor agrícola (NSa/VAa) e excedente líquido/valor adicionado total (NSa/VAt). As duas relações apresentam evolução semelhante àquela do excedente líquido da Figura 5. Vale dizer que NSa/VAa apresenta variações anuais mais suaves que NSa/VAt. Com isso, tem-se que o deflacionamento parece não ter afetado seriamente as tendências. A relação NSa/VAa aumenta na década de 80 , mas na década de 90 tem-se taxa negativa de crescimento ( $-0,32 \%$ a.a.) sem significância estatística. Logo, confirma-se a estabilidade no período, como indica a Figura 6. 


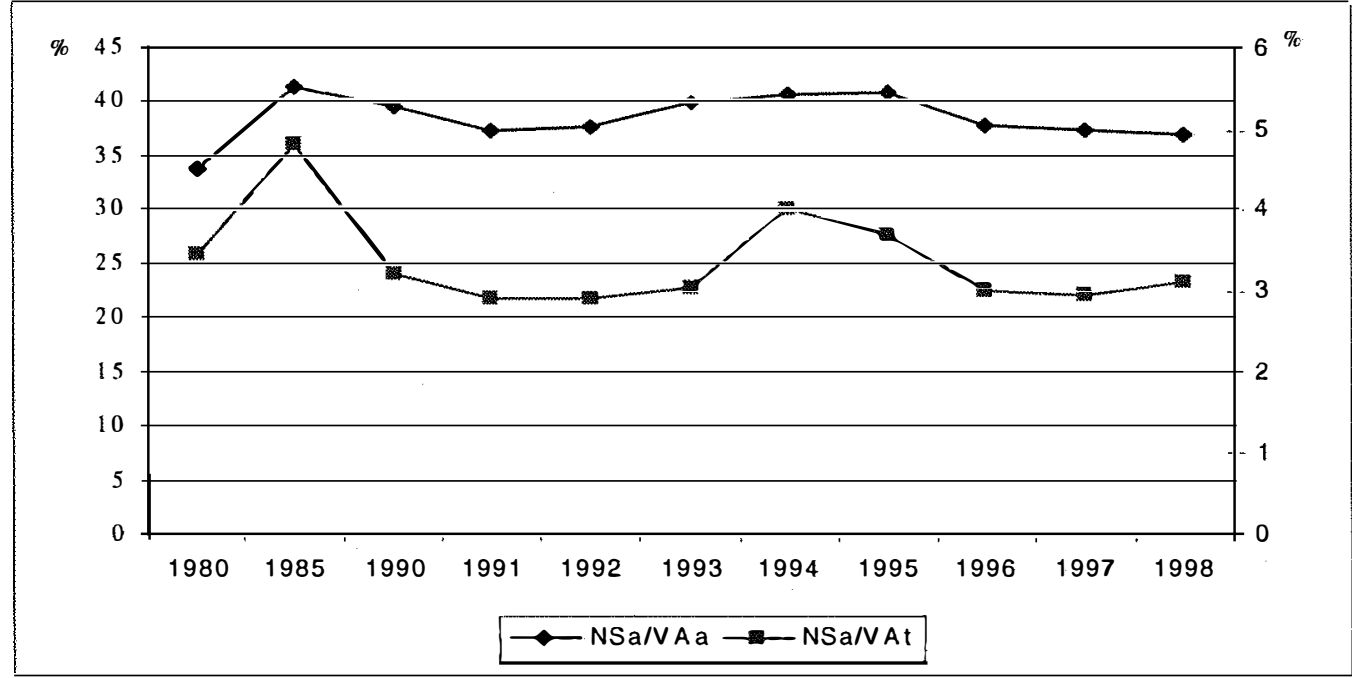

Figura 6. Evolução da relação entre excedente líquido/valor adicionado do setor agrícola (NSa/VAa) e de excedente líquido/valor adicionado total (NSa/VAt), de 1980 a 1998 (\%).

Fonte: elaboração do autor.

A relação $\mathrm{NSa} / \mathrm{VAt}$ apresenta-se também sem tendência definida na década de 90 (a taxa de crescimento estimada foi de $0,4 \%$ a.a., não significativa estatisticamente). Percebe-se, dos dados da Tabela 6, recuperação expressiva no ano de 1994, quando aumenta um ponto percentual, mas em 1996 já estava de volta aos 3\%, patamar típico da década.

Também no caso do excedente líquido parece haver coerência em relação ao cenário macroeconômico. De fato, a evolução do excedente líquido é parecida com a do valor adicionado do setor agrícola, o que é explicado, em parte, pela referida estabilidade da função consumo (Figura 5). No limite, se a proporção de tal valor adicionado despendida em consumo fosse constante, o excedente líquido teria evolução igual à do valor adicionado do setor agrícola. Como os valores de valor adicionado são maiores que os de consumo, seria necessário, para que o consumo determinasse a evolução do excedente líquido, que as variações neste último fossem proporcionalmente superiores às do valor adicionado. Assim, a consistência entre as estimativas de 
excedente líquido e os fatos macroeconômicos pode ser avaliada principalmente através da evolução do valor adicionado total e do setor agrícola.

O ano de 1991 foi marcado pelo pobre desempenho da economia do país, apesar da redução na taxa de inflação com o Plano Collor II (IBGE, 1997b). Com a volta da inflação no início de 1992, a política monetária elevou muito as taxas de juros o que, somado às incertezas no campo político, determinou a contração do nível geral de atividade. A partir de 1993 aparecem sinais de recuperação em razão da normalização do processo político e pelo abrandamento da política monetária.

Segundo Pinheiro (1995), os aumentos da renda real e da oferta de crédito, em função do Plano Real, aceleraram o processo de crescimento. Para o IBGE (1997b), o ano de 1994 apresentou a mais elevada taxa de crescimento da economia no período. O aumento dos juros reais, contração na base monetária e redução no crédito no segundo trimestre do ano em 1995 provocaram sinais de desaquecimento da economia no início de 1996, que aliados ao melhor desempenho do setor externo, levaram o governo a uma flexibilização das políticas monetárias e de crédito. Isso possibilitou uma recuperação da taxa de crescimento real do produto no segundo e terceiro trimestres do ano. O primeiro semestre de 1997 apontava um panorama de recuperação do crescimento econômico (IBGE, 1998b). Devido à instabilidade no mercado financeiro internacional não foi possível manter a política de redução gradual nas taxas de juros iniciada no ano anterior. Mesmo assim, houve aumento real de 3,77\% no PIB. Já em 1998 o nível de atividade manteve-se praticamente estável, com variação real de - 0,12\% (IBGE, 1999e). No primeiro semestre houve sinais de reação, mas a interrupção do fluxo de capitais do exterior levou o governo a elevar bruscamente as taxas de juros.

A evolução do valor adicionado do setor agrícola, e do excedente líquido, mostram boa aderência em relação ao comportamento geral da economia descrito acima, principalmente até 1997. Para 1998 a análise acima mostra estabilidade, enquanto aumentaram o valor adicionado e o excedente líquido do setor agrícola. Exceção feita à instabilidade política do início da década, o desempenho da agricultura esteve associado 
às políticas macroeconômicas, notadamente monetária e cambial. A influência dessas políticas sobre o excedente líquido foi marcante, confirmando a afirmação de Schuh (1968) de que elas exercem forte influência sobre o desenvolvimento da agricultura. ${ }^{54}$

\subsection{O R1 - Excedente Financeiro do setor agrícola com base na estimativa de investimento Ia1}

Na Tabela 6 e na Figura 7 é possível visualizar que a evolução do excedente financeiro R1 é semelhante à do excedente líquido. As variações proporcionais são maiores no caso do R1 em virtude de sua menor magnitude em relação ao excedente líquido. A razão de tal semelhança, principalmente na década de 90 , é a pequena variação nos investimentos, Ia1, cujo valor ficou em torno de US $\$ 8,5$ bilhões, caindo levemente nos dois últimos anos.

De 1980 a 1985, o excedente financeiro R1 aumentou 30,2\%, passando de US $\$$ 15,1 bilhões a US $\$ 19,7$ bilhões. Sofreu queda entre 1985 e 1990 de $54 \%$, chegando a US $\$ 9$ bilhões. Isto porque o Ial continuou aumentando $(20,1 \%)$ enquanto o excedente líquido registrava redução de $34,1 \%$.

\footnotetext{
${ }^{54} \mathrm{O}$ leitor pode notar ainda que os dados de variação do PIB no parágrafo anterior não coincidem exatamente com aqueles apresentados na Tabela 6 porque o PIB corresponde à soma dos valores adicionados pelos setores a custo de fatores e a referida Tabela apresenta dados a preços básicos.
} 


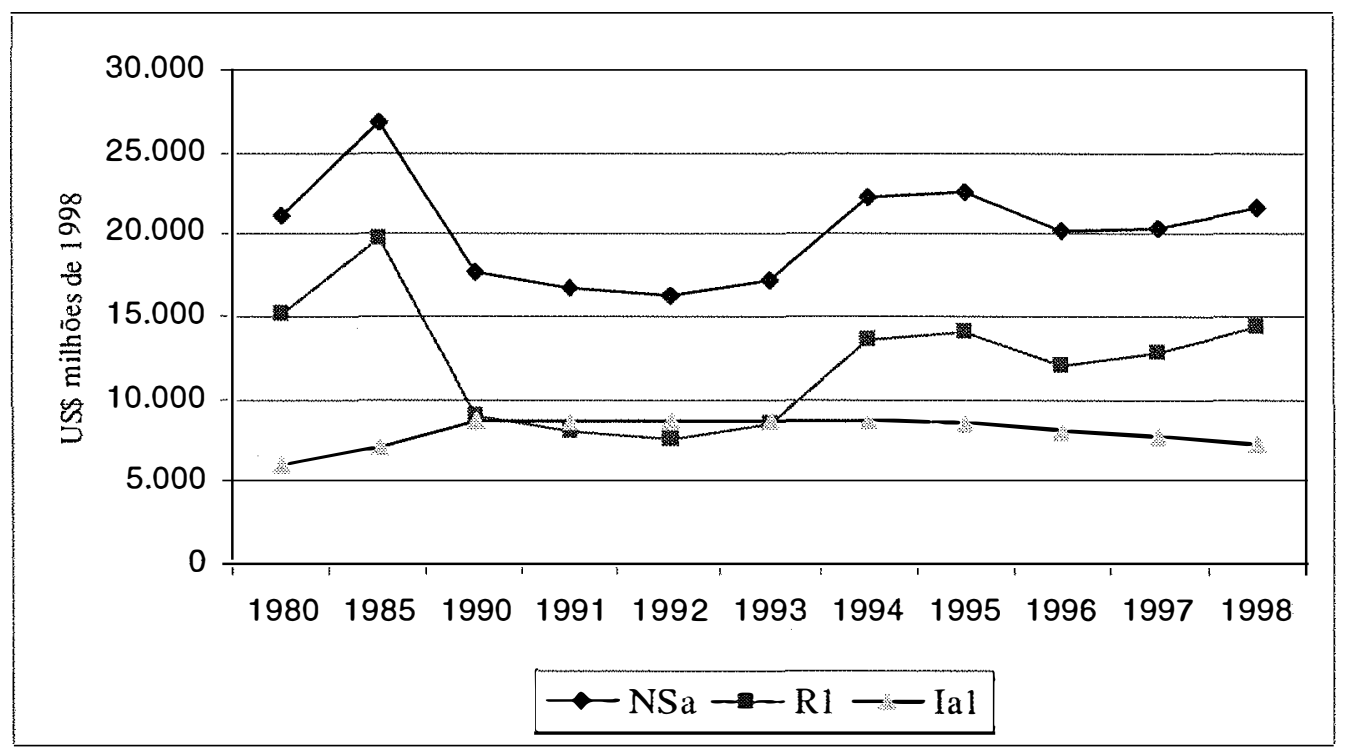

Figura 7. Evolução do excedente líquido (NSa), do excedente financeiroR 1 e do investimento Ial de 1980 a 1998 (US\$ milhões de 1998).

Fonte: elaboração do autor.

Na década de 90 o excedente financeiro R1 apresentou, ao final, valor bastante superior ao do início. Houve elevação de 59,7\%, que corresponde a um crescimento estimado e significativo, de $8,14 \%$ a.a. Assim como no caso do excedente líquido, observam-se três subperíodos. No período de 1990 a 1992 há queda de 15,5\% no Rl, que se recupera em 1993. Aumenta então até 1995, quando atinge seu maior valor na década, US\$14,1 bilhões. A partir daí sofre redução em 1996, com recuperação parcial até 1998 (aumentou 13,1\% de 1997 para 1998).

Também no caso do excedente financeiro foram calculadas as proporções entre seus valores e os valores adicionados do setor agrícola e da economia como um todo, $(\mathrm{R} l / \mathrm{VAa})$ e $(\mathrm{R} 1 / \mathrm{VAt})$, respectivamente. Essas relações aparecem na Tabela 6 e na Figura 8. As tendências neste caso são estatisticamente significativas. A evolução da relação $\mathrm{R} 1 / \mathrm{VAa}$ é semelhante à da relação NSa/VAa. É possível perceber ligeira tendência de elevação, tanto em Rl/VAa quanto em Rl/VAt a partir do início da década de 90 . 

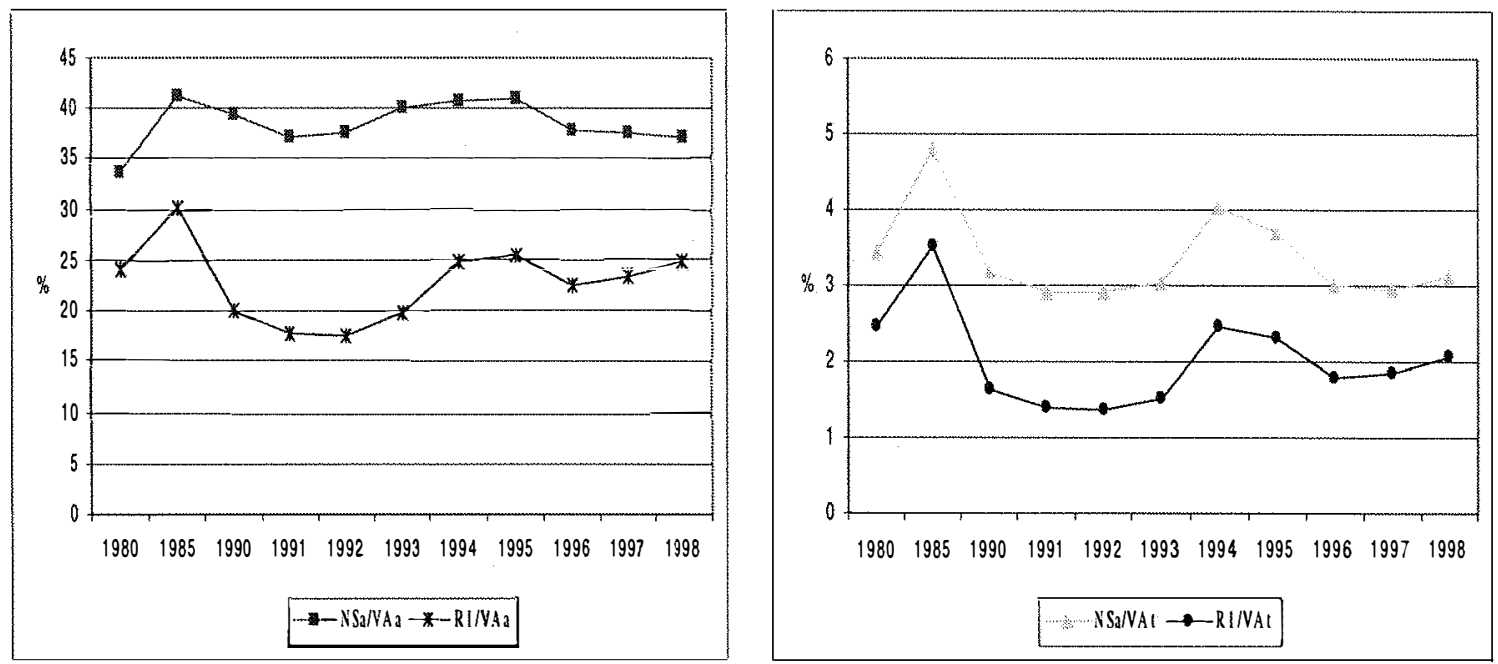

Figura 8. Evolução das relações excedente líquido/valor adicionado do setor agrícola (NSa/VAa), excedente financeiro R1/valor adicionado do setor agrícola (R1/VAa), excedente líquido/valor adicionado total (NSa/VAt) e excedente financeiro R1/valor adicionado do setor agrícola (R1/VAt), de 1980 a 1998 $(\%)$.

Fonte: elaboração do autor.

\subsubsection{Transferências visíveis (RV1) e invisíveis (RI1) relativas ao excedente financeiro R1}

No Capítulo 3 foi mostrado que, do ponto de vista setorial, é necessário considerar as transferências que ocorrem em função de variações nos termos de troca. A Tabela 8 e a Figura 9 mostram a evolução das relações de troca da agricultura brasileira no período de 1990 a 1998. 
Tabela 8. Evolução do Índice de Preços Recebidos pelos agricultores (IPR), Índice de Preços Pagos (IPP), IGP-DI e dos termos de troca (IPR/IPP) de 1990 a 1998.

\begin{tabular}{ccccc}
\hline Ano & IPR & IPP & IGP-DI & IPR/IPP \\
\hline 1990 & 0,002 & 0,003 & 0,00226 & 0,667 \\
1991 & 0,01 & 0,015 & 0,0116 & 0,667 \\
1992 & 0,114 & 0,159 & 0,127 & 0,717 \\
1993 & 2,67 & 3,113 & 2,799 & 0,858 \\
1994 & 70,348 & 71,441 & 70,162 & 0,985 \\
1995 & 105,057 & 125,843 & 117,492 & 0,835 \\
1996 & 117,128 & 144,119 & 130,528 & 0,813 \\
1997 & 128,048 & 154,506 & 140,856 & 0,829 \\
1998 & 137,453 & 159,63 & 146,33 & 0,861 \\
\hline
\end{tabular}

Fonte: IPR e IPP, Agroanalysis; IGP-DI, Conjuntura Econômica.

Nota: todos os índices, base Agosto de $1994=100$.

Dois aspectos devem ser ressaltados. O primeiro tem a ver com o desempenho do setor agrícola. É que a evolução dos termos de troca foi favorável no período como um todo. Houve queda somente nos anos de 1995 e 1996. Esta tendência aparece relatada também em Go (1997). Este autor trabalhou com duas formas de termos de troca, a relação entre o Índice de Preços ao Atacado - Oferta Global - Produtos Agrícolas (IPAOG-A) e o Índice de Preços ao Atacado - Oferta Global - Produtos Industriais (IPG-OGI), de 1969 a 1995 e a relação entre o Índice de Preços Recebidos (IPR) e o IPG-OG-I de 1969 a 1985 e entre 1988 e 1995. O segundo aspecto está mais diretamente ligado ao presente estudo. A despeito da referida evolução favorável, em todos os anos o IPR foi menor que o Índice de Preços Pagos (IPP). Significa dizer que em todos os anos houve transferência invisível do setor agrícola para o não-agrícola. O motivo dessa transferência é o fato de os produtores agrícolas terem pago relativamente mais caro por aquilo que compraram do que receberam pelo que venderam. As magnitudes das transferências invisíveis devem ser decrescentes como sugere a evolução dos termos de troca.

Rezende (1992) também usa, para o cálculo dos preços relativos, o IPA-OG-A e o IPA-OG-I. No presente trabalho são usados o IPP e o IPR. De acordo com o próprio Rezende, o IPP, por exemplo, inclui itens como mão-de-obra e insumos de origem agrícola e baseia-se em preços efetivamente praticados. O fato de considerar insumos de origem agrícola não é favorável. Ideal seria se incluísse apenas os preços pagos por bens 
e serviços de outros setores da economia, mas como IPP, IPR e IGP-DI têm mesma fonte, é possível obter maior consistência entre os resultados que levam e os que não levam em conta as transferências via termos de troca. Outro aspecto é que os cálculos e deflacionamentos de Ishikawa (1967a) e Evangelista (1997) foram feitos utilizando tais tipos de índices.

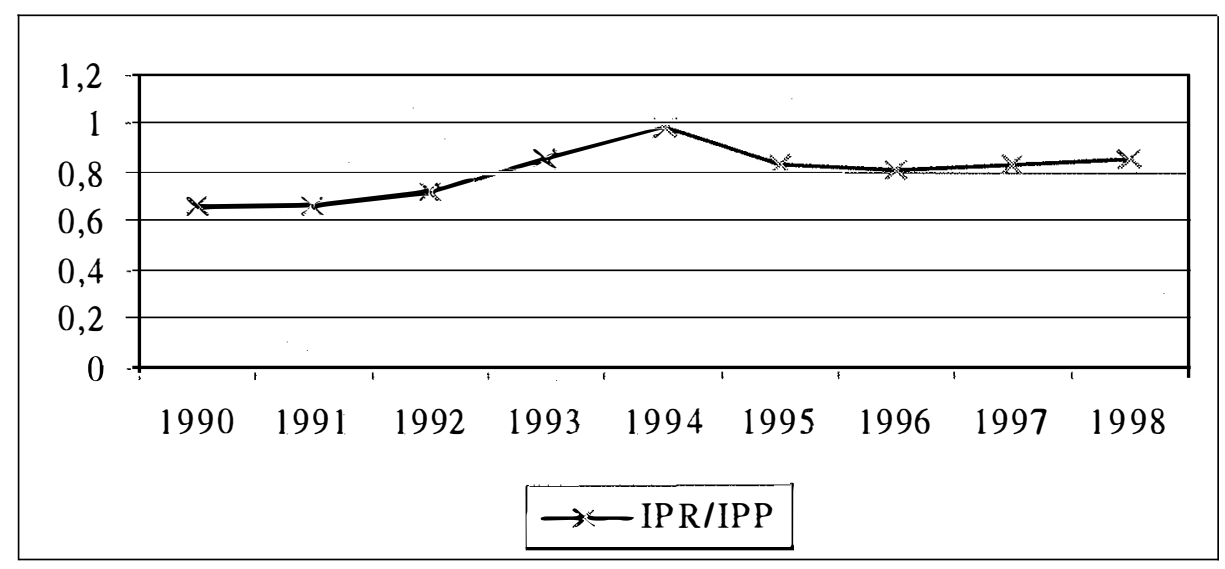

Figura 9. Evolução dos termos de troca IPR/IPP de 1990 a 1998.

Fonte: Agroanalysis.

A Tabela 9 e a Figura 10 mostram os resultados para as transferências visíveis (RV1) e invisíveis (RI1) e o total das transferências visíveis e invisíveis (RVI1), juntamente com os valores do excedente financeiro R1, a título de comparação. É importante destacar que existe clara influência do tipo de índice utilizado. A base do IPP e do IPR é o mês de Agosto de 1994, para o qual os dois índices assumem o valor 100. Por essa razão a relação IPR/IPP se aproxima de 1 no ano de 1994 e, por conseguinte, as transferências visíveis são menores neste ano. 
Tabela 9. Evolução das transferências invisíveis (RI1), visíveis (RV1) e totais (RVI1), de excedente financeiro R1 (US\$ milhões de 1998) e das relações RI1/RVI1, RVI1/R1, RVIl/VAa e RVI1/VAt de 1990 a 1998.

\begin{tabular}{ccccccccc}
\hline \multirow{2}{*}{ Ano } & RIl & RV1 & RVI1 & Rl & RI1/RVIl & RVI1/R1 RVI1/VAa RVI1/VAt \\
\cline { 2 - 9 } & \multicolumn{3}{c}{ (US $\$$ milhões de 1998) } & \multicolumn{3}{c}{$(\%)$} \\
\hline 1990 & $14.726,05$ & $9.576,72$ & $24.302,77$ & $9.022,31$ & 60,59 & 269,36 & 54,17 & 4,39 \\
1991 & $15.541,89$ & $8.693,53$ & $24.235,41$ & $7.978,43$ & 64,13 & 303,76 & 54,07 & 4,21 \\
1992 & $12.271,63$ & $7.980,70$ & $20.252,33$ & $7.626,43$ & 60,59 & 265,55 & 46,77 & 3,61 \\
1993 & $5.610,92$ & $8.429,34$ & $14.040,26$ & $8.560,14$ & 39,96 & 164,02 & 32,62 & 2,47 \\
1994 & 684,80 & $12.730,19$ & $13.414,99$ & $13.588,26$ & 5,10 & 98,72 & 24,51 & 2,41 \\
1995 & $8.294,70$ & $14.802,52$ & $23.097,22$ & $14.090,66$ & 35,91 & 163,92 & 41,80 & 3,76 \\
1996 & $9.433,98$ & $12.642,88$ & $22.076,86$ & $12.077,65$ & 42,73 & 182,79 & 41,25 & 3,29 \\
1997 & $8.578,78$ & $13.170,31$ & $21.749,09$ & $8.408,92$ & 39,44 & 170,64 & 39,91 & 3,14 \\
1998 & $7.111,95$ & $14.412,44$ & $21.524,39$ & $14.412,44$ & 33,04 & 149,35 & 36,80 & 3,10 \\
\hline
\end{tabular}

Fonte: elaboração do autor.

A magnitude e a evolução do excedente financeiro $\mathrm{R} 1$ e das transferências visíveis são semelhantes em razão dos índices utilizados em suas obtenções, IGP-DI e IPR, terem mesma fonte e mesma base. As transferências invisíveis tiveram seu valor máximo em 1991, US\$ 15,5 bilhões, caindo a partir de então. Chegam ao final do período analisado com o valor de US\$7,1 bilhões, menor que as transferências visíveis (RV1) de US\$14,4 bilhões. Tal queda é explicada pela melhoria nos termos de troca da agricultura. 


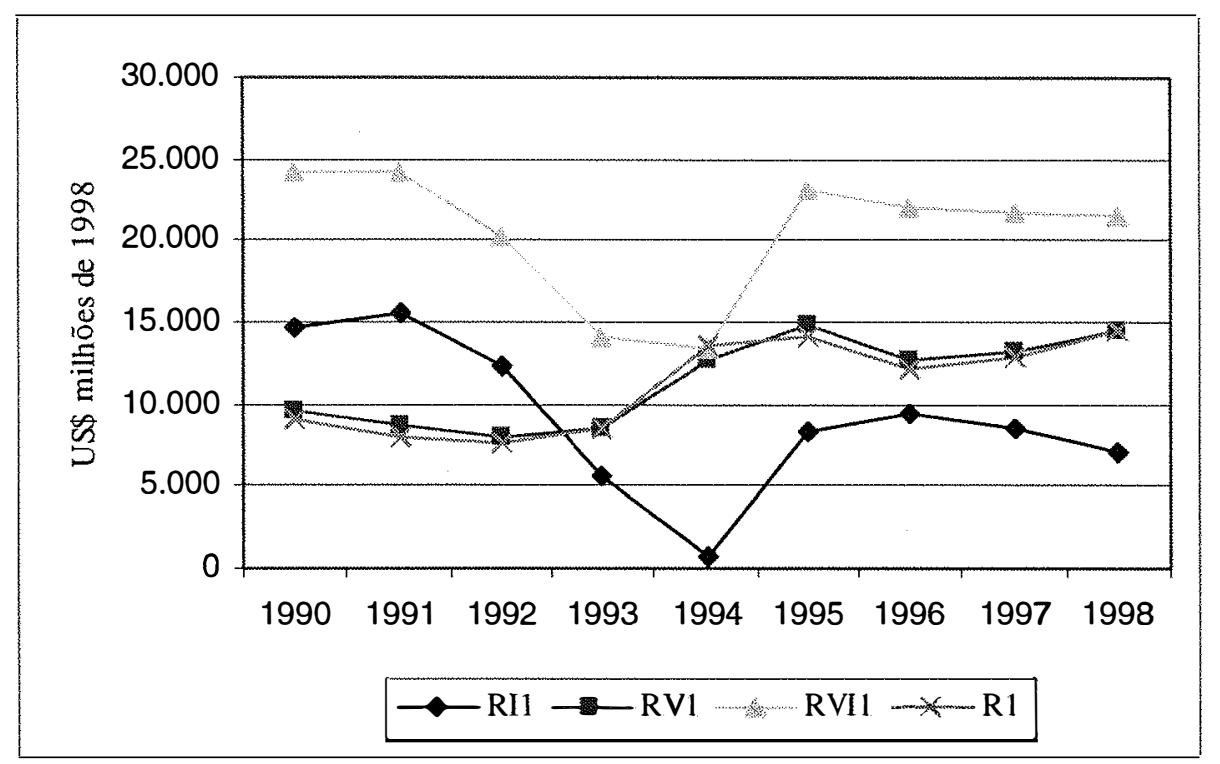

Figura 10. Evolução das transferências invisíveis (RI1), visíveis (RV1), totais (RVI1) e do excedente financeiro R1 de 1990 a 1998 (US\$ milhões de 1998).

Fonte: elaboração do autor.

O total do excedente financeiro considerando os termos de troca (RVI1) assume magnitudes consideravelmente maiores que as de excedente financeiro R1. A Tabela $9 \mathrm{e}$ a Figura 10 mostram, ainda, que o setor agrícola tem disponibilizado um excedente que teria representado mais de $50 \%$ de seu valor adicionado no início da década de 90 , chegando ao final deste período a $36,8 \%$ do valor adicionado. Essas grandezas corresponderiam, respectivamente, a $4,4 \%$ e $3,1 \%$ do valor adicionado total da economia.

\subsection{O R2 - Excedente Financeiro do setor agrícola com base na estimativa de investimento Ia2}

Também neste caso a evolução é semelhante à do excedente líquido (Tabela $6 \mathrm{e}$ Figura 11). A principal diferença em relação ao excedente financeiro R1 é que os valores de R2 são maiores em função de o investimento Ia2 ser menor que o Ia1 (investimento obtido com base na Matriz de Insumo-Produto de 1980 e variação igual à do estoque de 
tratores). No caso do excedente financeiro R2, a variação no Ia2 entre os anos é maior. No entanto, as magnitudes do Ia2 são as menores dentre as estimativas de investimento no setor agrícola. Por essa razão, não são capazes de fazer com que o R2 apresente a mesma intensidade de variação.

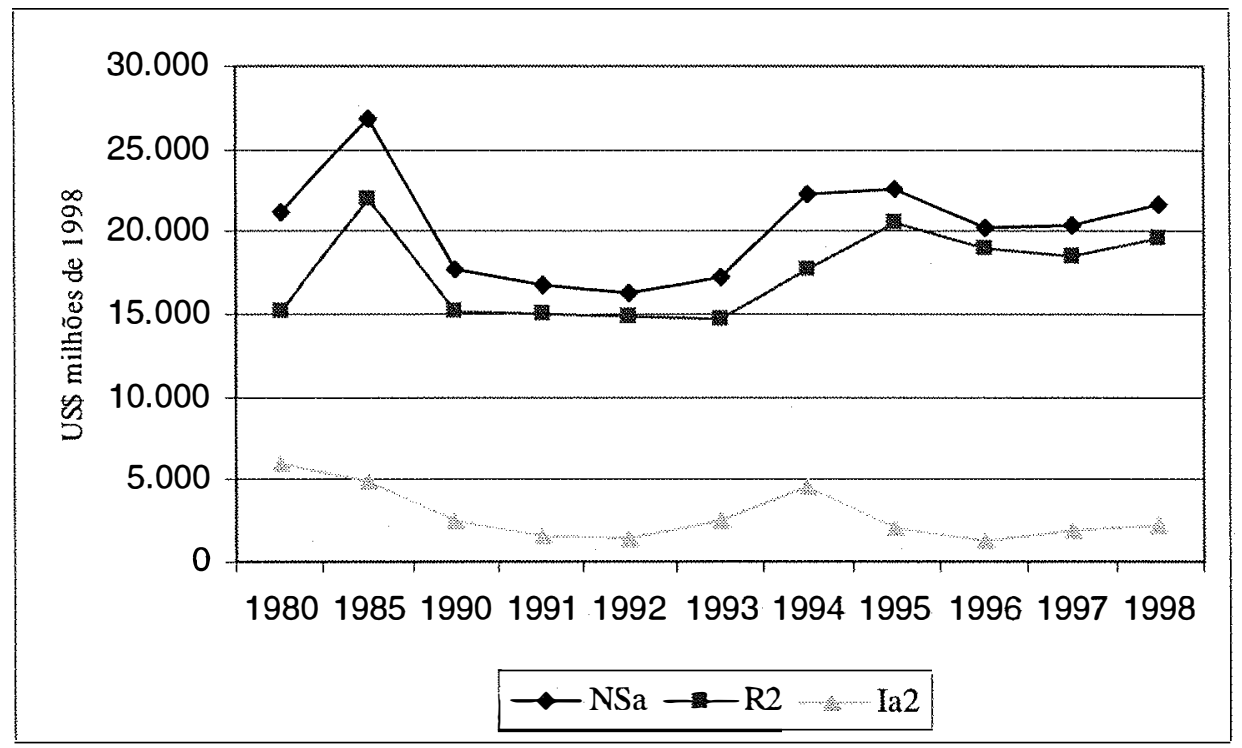

Figura 11. Evolução do excedente líquido (NSa), do excedente financeiro R2 e do investimento Ia2 de 1980 a 1998 (US\$ milhões de 1998).

Fonte: elaboração do autor.

O excedente financeiro R2 apresenta em 1990 valor semelhante ao de 1980, de US $\$ 15,1$ bilhões. Houve aumento em 1985, quando chegou a US\$ 22 bilhões, seu maior valor no período analisado. A redução do R2 entre 1985 e $1990(31,1 \%)$ foi menor que a do excedente líquido em função da queda dos investimentos agrícolas (47,9\%).

$\mathrm{Na}$ década de 90 há variação positiva do excedente financeiro R2, proporcionalmente a menor variação entre as verificadas nas medidas de excedente financeiro, da ordem de $28,8 \%$. Corresponde a um crescimento, significativo, de $4,19 \%$ a.a., bastante influenciado pelo valor adicionado do setor agrícola, principalmente até 1994. No caso do R2 também são identificados três subperíodos, 1990-93, 1993-95 e 
1995-98, o primeiro e o último de relativa estabilidade e o intermediário de elevação. Com isso, o excedente financeiro R2 ficou num patamar de US\$ 15 bilhões no início da década, atingindo ao final da mesma a casa dos US\$19 bilhões.

De 1990 a 1993, o excedente financeiro R2 sofre redução de 3,3\%, passando de US\$15,1 bilhões a US \$14,7 bilhões, ou seja, praticamente estável. O R2 aumenta em 1994 e 1995, sendo que neste último ano atinge seu maior valor na década: US\$20,5 bilhões. A partir de então, cai até 1997, quando soma US\$18,6 bilhões, recuperando-se ligeiramente em 1998. A proporção do excedente financeiro R2 em relação ao valor adicionado do setor agrícola (R2/VAa) aumentou de 24\% em 1980 para 34\% em 1985. Fica neste mesmo patamar de 1990 a 1996. Verificam-se dois pequenos desvios, quando assume 32\% em 1994 (ocorrido principalmente em função do maior aumento do valor adicionado do setor agrícola) e $37 \%$ em 1995. Neste caso, diferentemente da relação Rl/V Aa, não há tendência significativa ao longo da década de 90 . A evolução da relação R2/VAt é semelhante à do próprio R2 (Figura 12).
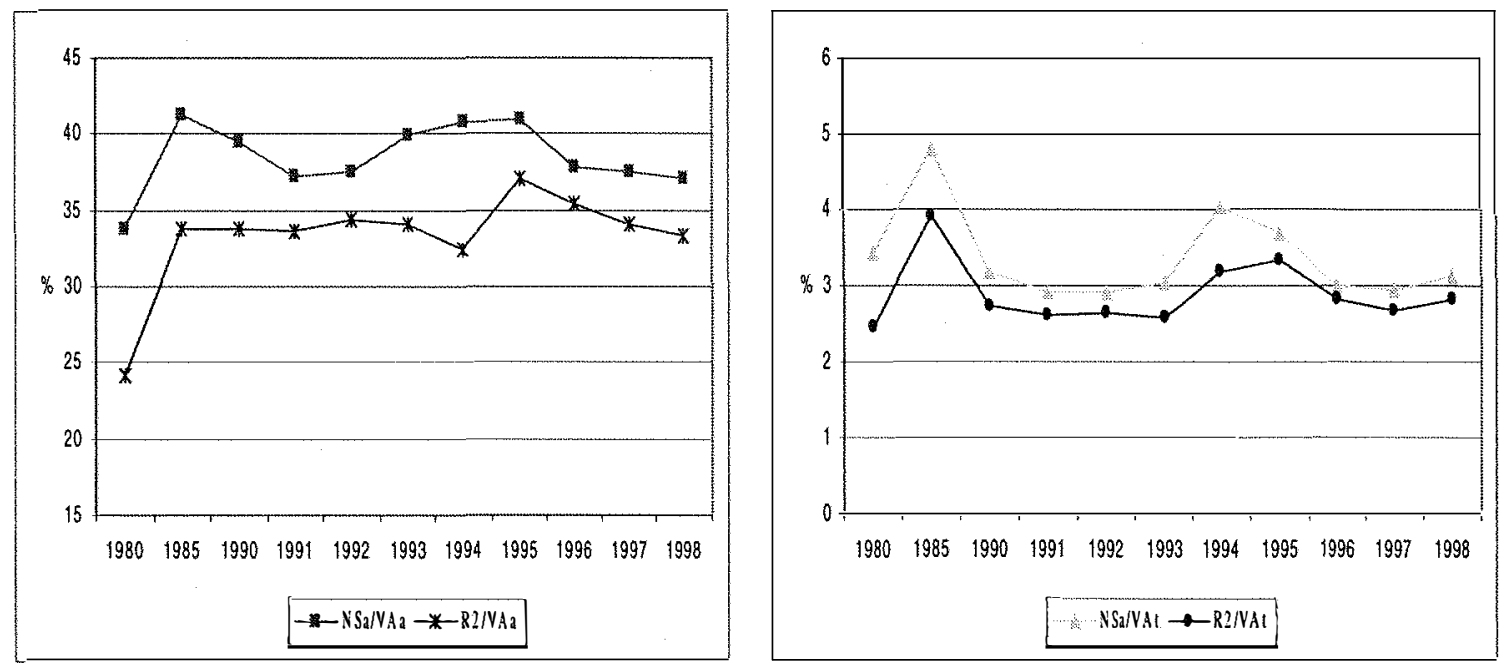

Figura 12. Evolução das relações excedente líquido/valor adicionado do setor agrícola ( $\mathrm{NSa} / \mathrm{VAa}$ ), excedente financeiro $\mathrm{R} 2 / \mathrm{valor}$ adicionado do setor agrícola (R2/VAa), excedente líquido/valor adicionado total (NSa/VAt) e excedente financeiro R2/valor adicionado do setor agrícola (R2/VAt), de 1980 a 1998 $(\%)$.

Fonte: elaboração do autor 


\subsubsection{As transferências visíveis (RV2) e invisíveis (RI2) relativas ao excedente}

\section{financeiro R2}

A Tabela 10 e a Figura 13 mostram os resultados considerando os termos de troca. De forma geral, a evolução é praticamente a mesma do caso anterior. O excedente financeiro R2 e as transferências visíveis (RV2) são também semelhantes. A diferença está na magnitude das transferências invisíveis (RI2). Aparentemente existe contra-senso pois, apesar de IPR ser menor que IPP em todo o período, o RI2 é também menor que o RV2. Isso se deve ao fato de as entradas no setor (notadamente os investimentos) serem inferiores às do caso anterior. Com isso, o componente invisível, além de menor em valores absolutos, é proporcionalmente menor que o visível.

Também neste caso RI2 apresenta tendência decrescente. Inicialmente assume o valor de US\$12,2 bilhões em 1990, atingindo seu valor máximo em 1991, da ordem de US\$ 12,6 bilhões. Chega em 1998 ao valor de US\$ 6,3 bilhões. O valor total do excedente financeiro considerando os termos de troca (RVI2) é também expressivamente maior que o de excedente financeiro R2 para a maior parte da década de 90 . Em termos proporcionais, essas magnitudes representam cerca de $63 \%$ e $44 \%$ do valor adicionado do setor agrícola no início e no final da década e 5,1\% e 3,7\% do valor adicionado total, respectivamente.

Tabela 10. Evolução das transferências invisíveis (RI2), visíveis (RV2), totais (RVI2), do excedente financeiro R2 (US $\$$ milhões de 1998) e das relações RI2/RVI2, RVI2/R2, RVI2/VAa e RVI2/VAt de 1990 a 1998.

\begin{tabular}{|c|c|c|c|c|c|c|c|c|}
\hline \multirow{2}{*}{ Ano } & RI2 & RV2 & RVI2 & $\mathrm{R} 2$ & RI2/RVI2 & RVI2/R2 & RVI2/VA & RVI2/NAt \\
\hline & \multicolumn{4}{|c|}{ (US\$ milhões) } & \multicolumn{4}{|c|}{$(\%)$} \\
\hline 1990 & $12.211,28$ & $16.072,90$ & $28.284,19$ & $15.142,41$ & 43,17 & 186,79 & 63,05 & 5,10 \\
\hline 1991 & $12.553,73$ & $16.412,58$ & $28.966,31$ & $15.062,53$ & 43,34 & 192,31 & 64,62 & 5,03 \\
\hline 1992 & $9.779,57$ & $15.562,67$ & $25.342,24$ & $14.871,83$ & 38,59 & 170,40 & 58,52 & 4,52 \\
\hline 1993 & $4.619,96$ & $14.425,50$ & $19.045,46$ & $14.649,35$ & 24,26 & 130,01 & 44,25 & 3,35 \\
\hline 1994 & 615,76 & $16.615,86$ & $17.231,61$ & $17.735,84$ & 3,57 & 97,16 & 31,49 & 3,10 \\
\hline 1995 & $7.002,46$ & $21.539,14$ & $28.541,60$ & $20.503,32$ & 24,53 & 139,20 & 51,66 & 4,65 \\
\hline 1996 & $7.863,08$ & $19.865,45$ & $27.728,53$ & $18.977,31$ & 28,36 & 146,11 & 51,82 & 4,13 \\
\hline 1997 & $7.386,17$ & $19.167,21$ & $26.553,37$ & $18.549,64$ & 27,82 & 143,15 & 48,73 & 3,84 \\
\hline 1998 & $6.290,13$ & $19.506,05$ & $25.796,19$ & $19.506,05$ & 24,38 & 132.25 & 44,10 & 3,71 \\
\hline
\end{tabular}

Fonte: elaboração do autor. 


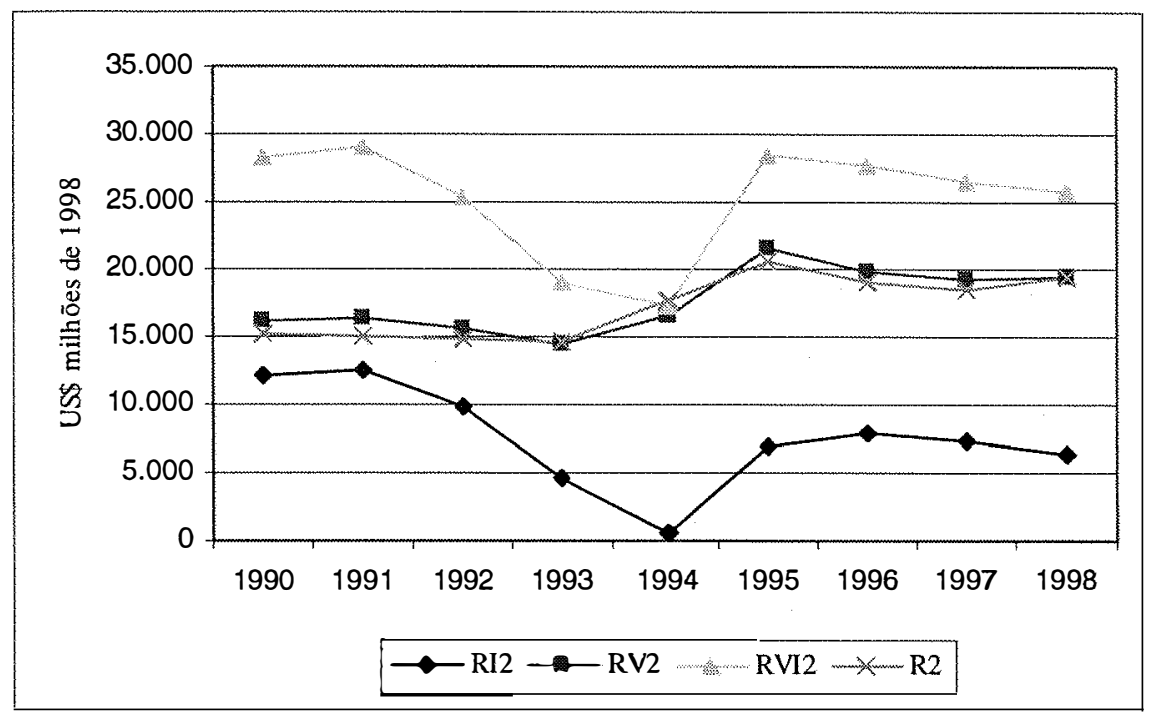

Figura 13. Evolução das transferências invisíveis (RI2), visíveis (RV2), totais (RVI2) e do excedente financeiro R2 de 1990 a 1998 (US\$ milhões de 1998).

Fonte: elaboração do autor.

\subsection{O R3 - Excedente Financeiro do setor agrícola com base na estimativa de investimento Ia3}

Diferentemente dos casos anteriores, o excedente financeiro R3 não se assemelha tanto ao excedente líquido (Tabela 6 e Figura 14). As magnitudes e as variações dos investimentos Ia3 são mais expressivas. O Ia3 apresenta maior variação que o Ia1 (investimento obtido com base na Matriz de Insumo-Produto de 1980 e variação igual à do estoque de tratores) e o Ia2 (investimento obtido com base na Matriz de InsumoProduto de 1980 e variação igual à da venda de tratores). Principalmente em relação ao primeiro. Além disso, tem magnitudes superiores às do Ia2. Ao contrário do observado com excedente financeiro R2, o Ia3 consegue imprimir ao excedente financeiro R3 as características de sua evolução. 


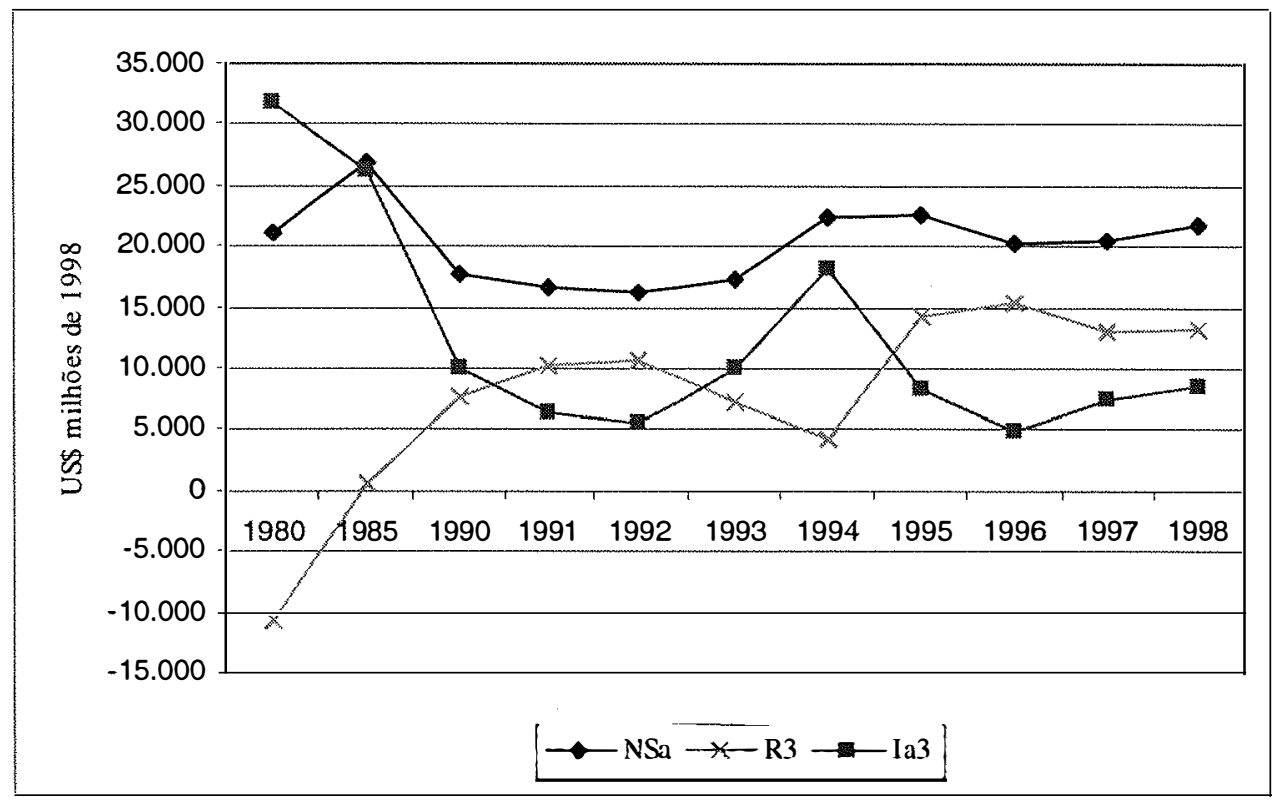

Figura 14. Evolução do excedente líquido (NSa), do excedente financeiro R3 e do investimento Ia3 de 1980 a 1998 (US\$ milhões de 1998).

Fonte: elaboração do autor.

O excedente financeiro R3 apresentou elevação na década de 80 . O investimento relativamente alto no primeiro ano da década fez com que o excedente fosse negativo em US\$ 10,7 bilhões. Foi a única ocorrência valor negativo em todas as versões estudadas. Houve recuperação, passando as um valores positivos de US $\$ 576$ milhões em 1985 e US\$7,7 bilhões em 1990. Tal recuperação foi determinada principalmente pela queda dos investimentos Ia3. Note-se que o excedente líquido foi decrescente entre 1985 e 1990 (redução de 34,1\%), mas o R3 aumentou porque a redução em Ia3 foi ainda maior, da ordem de $61,9 \%$.

Na década de 90, o excedente financeiro R3 também apresenta crescimento de 7,35\% a.a. (significativo, neste caso, a 20\%). A elevação até 1992 está associada à queda no investimento Ia3. O Ia3 aumenta em 1993 e 1994, ano em que atinge seu maior valor na década: US\$ 18,1 bilhões. Isso provocou redução em R3 no mesmo período, chegando em 1994 ao menor valor na década: US\$ 4,2 bilhões. O aumento do 
investimento entre 1993 e 1994 (80\%) fez cair o R3, apesar de excedente líquido ter aumentado $30 \%$.
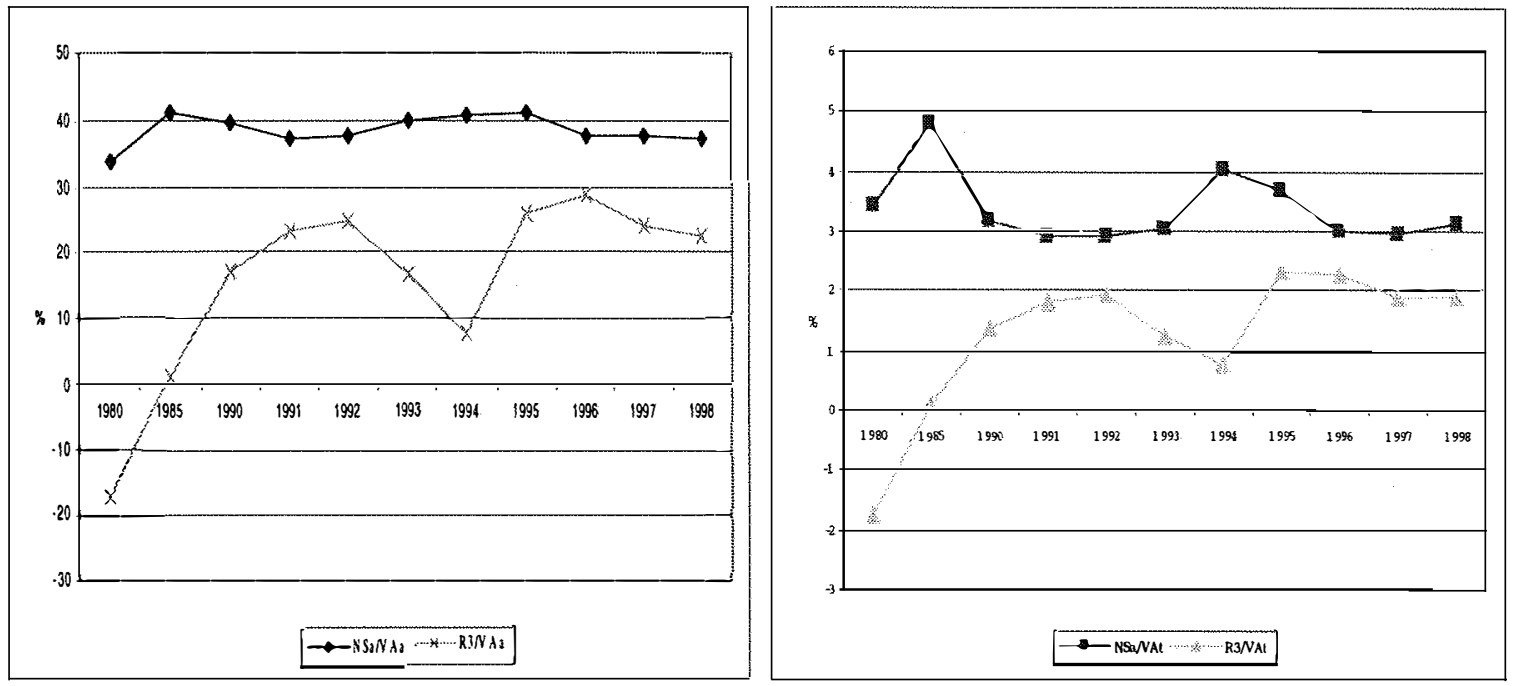

Figura 15. Evolução das relações excedente líquido/valor adicionado do setor agrícola (NSa/VAa), excedente financeiro R3/valor adicionado do setor agrícola (R3/VAa), excedente líquido/valor adicionado total (NSa/VAt) e excedente financeiro R3/valor adicionado do setor agrícola (R3/VAt), de 1980 a 1998 $(\%)$.

Fonte: elaboração do autor.

A redução no investimento entre 1994 e 1995 (54,3\%) provoca expressivo aumento do excedente financeiro R3 nesse último ano. O R3 aumentou ainda em 1996, caindo então e chegando em 1998 a US\$ 13,1 bilhões, ainda assim valor 71,1\% maior que o de 1990. Da Tabela 6 e da Figura 15 é possível perceber que as evoluções das relações R3/VAa e R3/VAt são semelhantes à descrita para R3. No entanto, as tendências dessas relações não são significativas.

\subsubsection{As transferências visíveis (RV3) e invisíveis (RI3) relativas ao excedente financeiro R3}

A evolução das transferências visíveis (RV3) e invisíveis (RI3) é semelhante à verificada nos casos anteriores (Tabela 11 e Figura 16). As magnitudes do total do 
excedente, considerando os termos de troca (RVI3), são bastante superiores ao excedente financeiro R3 na maior parte dos anos. Em termos proporcionais, o RVI3 corresponde a $52,2 \%$ e $34,9 \%$ do valor adicionado do setor agrícola no início e final da década e a $4,2 \%$ e $2,9 \%$ do valor adicionado total, respectivamente.

Tabela 11. Evolução das transferências invisíveis (RI3), visíveis (RV3) e totais (RVI3), do excedente financeiro R3 (US\$ milhões de 1998) e das relações RI3/RVI3, RVI3/R3, RVI3/VAa e RVI3/VAt de 1990 a 1998.

\begin{tabular}{ccccccccc}
\hline \multirow{2}{*}{ Ano } & RI3 & RV3 & RVI3 & R3 & \multicolumn{2}{c}{ RI3/RVI3 RVI3/R3 RVI3/VAa RVI3/VAt } \\
\cline { 2 - 9 } & \multicolumn{3}{c}{ (US\$ milhões de 1998) } & \multicolumn{3}{c}{$(\%)$} \\
\hline 1990 & $15.282,48$ & $8.139,34$ & $23.421,82$ & $7.668,14$ & 65,25 & 305,44 & 52,21 & 4,23 \\
1991 & $14.556,75$ & $11.238,35$ & $25.795,10$ & $10.313,92$ & 56,43 & 250,10 & 57,55 & 4,48 \\
1992 & $11.198,88$ & $11.244,49$ & $22.443,37$ & $10.745,34$ & 49,90 & 208,87 & 51,83 & 4,00 \\
1993 & $5.845,20$ & $7.011,74$ & $12.856,94$ & $7.120,54$ & 45,46 & 180,56 & 29,87 & 2,26 \\
1994 & 841,21 & $3.926,95$ & $4.768,16$ & $4.191,64$ & 17,64 & 113,75 & 8,71 & 0,86 \\
1995 & $8.249,32$ & $15.039,10$ & $23.288,43$ & $14.315,87$ & 35,42 & 162,68 & 42,15 & 3,80 \\
1996 & $8.687,54$ & $16.074,79$ & $24.762,33$ & $15.356,12$ & 35,08 & 161,25 & 46,27 & 3,69 \\
1997 & $8.523,65$ & $13.447,50$ & $21.971,15$ & $13.014,22$ & 38,79 & 168,82 & 40,32 & 3,17 \\
1998 & $7.321,02$ & $13.116,63$ & $20.437,65$ & $13.116,63$ & 35,82 & 155,81 & 34,94 & 2,94 \\
\hline
\end{tabular}

Fonte: elaboração do autor.

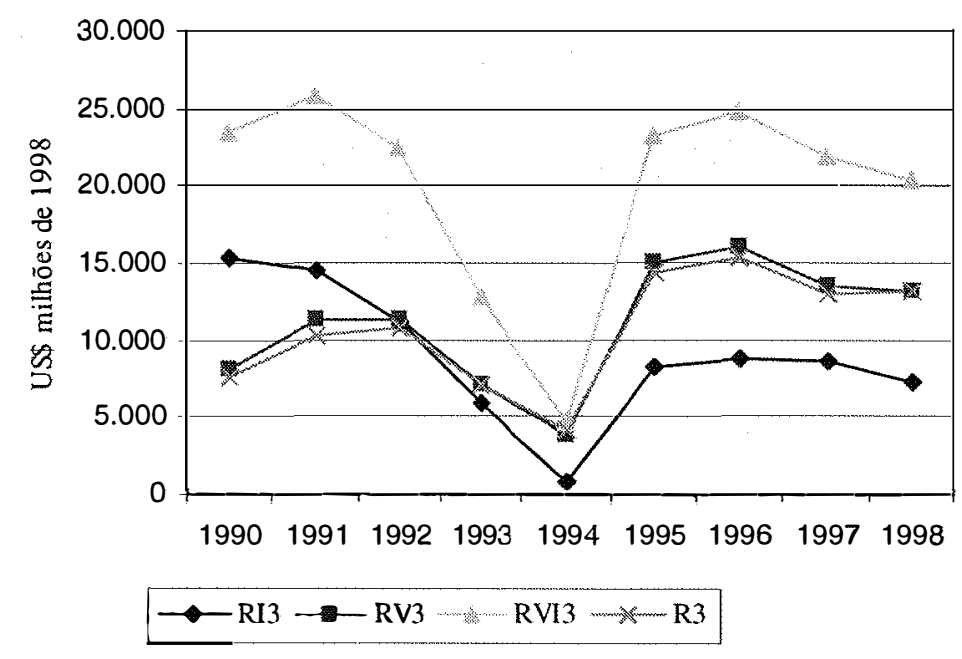

Figura 16. Evolução das transferências invisíveis (RI3), visíveis (RV3) e totais (RVI3), do excedente financeiro R3 de 1990 a 1998 (US\$ milhões de 1998).

Fonte: elaboração do autor. 


\subsection{Comentários finais}

Tanto as estimativas de investimento (principalmente aquelas com variação igual à das vendas de tratores, Ia2 e Ia3) quanto do excedente líquido apresentaram boa aderência em relação ao contexto econômico em geral. Adicionalmente, a evolução do excedente financeiro, medido por R1, R2 e R3, está de acordo com o desempenho do setor agrícola no período em análise. Bonelli \& Fonseca (1998) citam que, de acordo com diversos trabalhos, o crescimento da agricultura brasileira a partir da metade da década de 80 ocorreu com substanciais ganhos de produtividade, mas o desempenho não foi uniforme nas diversas culturas.

A área cultivada no Brasil cresceu de 1980 para 1985 e decresceu a partir de então e durante toda a década de 90, à exceção de 1993, segundo Ferreira Filho \& Costa (1999). Com isso, fica clara a intensificação da produção por área. Os autores construíram um índice da razão entre produção total em peso e área colhida total, com valor 100 em 1978. Tal índice alcançou os valores 109, 152, 163 e 223 em 1980, 1985, 1990 e 1998, respectivamente. Tal evolução mostra discrepância em relação ao valor adicionado do setor agrícola somente para 1985, o que é admissível e pode ser atribuído a problemas de metodologia e/ou deflacionamento.

A saída de recursos da agricultura em Formosa, segundo Johnston \& Kilby (1977) foi possível também graças a aumentos na produção agrícola que, naquele caso, foram conseguidos com pequena elevação no uso de insumos comprados. O caso brasileiro é diferente. Houve aumento na produtividade total dos fatores (Bonelli \& Fonseca, 1998) associada a aumento da produção. A produção da agricultura propriamente dita, em volume, foi crescente na década de 90 (Boletim do Banco Central), sendo também crescente a utilização de insumos. Como exemplo, a Associação Nacional para Difusão de Adubos e Corretivos Agrícolas (ANDA) informa que o consumo aparente de fertilizantes cresceu na década de 1990, passando de 8 milhões para 14 milhões de toneladas. 
Estes dados contrariam a afirmação de Syrquin (1988) de que a mecanização e o uso de insumos intermediários provocam redução no valor adicionado. Tudo leva a crer que o crescimento praticamente constante da agricultura brasileira nas décadas de 80 e 90 foi possível graças à queda nos custos de produção (Ferreira Filho, 1998). Ainda segundo Ferreira Filho \& Costa (1999), tal redução nos custos de produção tem a ver também com o fim dos subsídios e a conseqüente racionalização no uso de tratores (o que vale também para os demais insumos e bens de capital). O bom desempenho da agricultura nos anos 80 e 90 pode também ser explicado, segundo Barros (1999, p.33), pelo "acúmulo de capital físico e humano, aumento nos investimentos em pesquisa e extensão e melhoria da infra-estrutura básica" nos anos 70 e pela "progressiva redução na intervenção estatal no decorrer dos anos 80, associada ao aprendizado das modernas técnicas de produção" levando a um aumento de eficiência técnica. Ou seja, fatores como preços de insumos e crédito, desenvolvimento tecnológico e melhoria de infraestrutura levaram ao bom desempenho do setor.

Mesmo considerando as dificuldades para uma análise comparativa decorrentes da diversidade metodológica, os resultados desta pesquisa não são discrepantes em relação a outros estudos. Em termos gerais, Gutierrez \& Barbero (1988) também verificaram tendência crescente do excedente. Em termos da magnitude do excedente, Karshenas (1994) cita que o potencial de extração de grandes magnitudes de recursos da agricultura na China, estimado por Lee ${ }^{55}$, foi possível em razão do rápido crescimento da produtividade agrícola. A saída de recursos constituiu algo entre $40 \%$ a $50 \%$ das vendas do setor entre as décadas de 10 e 20, baixando para $30 \%$ na década de 30 , ficando neste nível até 1960 . No caso do Brasil, o excedente financeiro ficou entre $7,7 \%$ e $37 \%$ do valor adicionado do setor agrícola na década de 90 , estes, os valores extremos das três versões estudadas.

Quanto à magnitude das transferências via termos de troca, as informações disponíveis são de que, em 1977 no Irã, as transferências invisíveis (neste caso entrando

\footnotetext{
${ }^{55}$ Op. cit.
} 
no setor agrícola) foram maiores do que as atribuídas ao crescimento normal do valor adicionado no setor (Karshenas, 1994). O estudo de Ishikawa (1967a) revelou proporções entre transferências invisíveis/excedente de importações da ordem de 45\%,3\% e 16\%, respectivamente, na China em 1956, Taiwan em 1962 e Japão em 1964. As proporções encontradas para Taiwan por Yotopoulos \& Nugent (1976), em termos da saída líquida real da agricultura, de 28,6\%, 48,4\%, 6\% e - 16\% nos períodos de 1952 55, 1956-60, 1961-65 e 1966-70, respectivamente. Karshenas (1998) reporta que mais de 60\% das transferências feitas pela agricultura japonesa no período 1956-60 são devidas aos termos de troca adversos para o setor. Os valores da relação entre valor real das transferências invisíveis e o valor real total das transferências considerando os termos de troca no Brasil oscilam entre $3 \%$ e $63 \%$ na década de 90 . Ademais, os valores totais do excedente financeiro quando se consideram as transferências via alterações nos termos de troca, apesar de decrescentes chegam a representar três vezes os valores reais obtidos.

Isto posto, e concluindo as análises dos resultados, pode-se inferir que as medidas de excedente, tanto líquido quanto financeiro, mostram concordância com o desempenho e/ou a evolução da economia como um todo e do setor agrícola em particular. 


\section{CONCLUSÕES}

Uma primeira conclusão é que a percepção do papel da agricultura no desenvolvimento evoluiu ao longo do tempo. A literatura mostra que, de uma visão de agricultura como setor passivo, chegou-se a uma abordagem segundo a qual as relações e interações entre a agricultura e os outros setores devem ser necessariamente consideradas. Verificou-se também que as abordagens metodológicas de estimação de excedente acompanharam essa mudança de percepção. Outra questão de realce diz respeito ao papel da agricultura nos estágios mais avançados do desenvolvimento econômico. Mesmo perdendo em participação relativa, a agricultura continua sendo estrategicamente essencial, pois sua contribuição não se limita apenas à geração de emprego e renda. Os resultados do presente estudo confirmam a hipótese de a contribuição da agricultura brasileira em período recente ter sido significativa para o processo de formação de capital e crescimento da economia.

Em outras palavras, os resultados desta tese confirmam a hipótese levantada inicialmente de o excedente do setor agrícola brasileiro ser positivo no período de 1980 a 1998. Valor negativo de excedente financeiro só foi encontrado em um ano das estimativas. Além disso, os resultados confirmam, para a década de 90, a hipótese de excedente crescente em todas as versões estimadas.

As estimativas de investimento no setor agrícola mostraram-se coerentes com o cenário macroeconômico do período. Tudo indica que as variações nas vendas internas de tratores nacionais de rodas são boa proxy para as variações do investimento na agricultura. Na década de 90 há tendência nítida de elevação dos valores do excedente financeiro. No cenário mais pessimista, a agricultura brasileira disponibilizou para 
investimento em outros setores da economia a cifra de US\$ 7,7 bilhões em 1990 (1,38\% do valor adicionado total da economia), chegando ao final da década à cifra de US $\$ 13,1$ bilhões (de 1,89\% do valor adicionado total).

Apesar da recuperação no ano de 1994, os investimentos registraram sensível redução no período estudado. Isso obviamente influenciou a tendência crescente do excedente financeiro e pode estar associado ao aumento na produtividade dos fatores. Resta saber até quando tal queda nos investimentos poderá ocorrer sem prejuízo à produção e produtividade da agricultura, comprometendo portanto sua capacidade de contribuir positivamente para o crescimento econômico geral.

Os termos de troca, além de desfavoráveis para o setor, implicam pesadas transferências de recursos para o resto da economia, embora com tendência decrescente. No presente trabalho o excedente financeiro refere-se a um "balanço setorial". Se tal balanço é positivo para o setor agrícola, resta saber, e fica também para futuras investigações, quais setores estariam absorvendo tal excedente.

O fato de a tendência crescente nas estimativas de excedente estar de acordo com o desempenho da agricultura ao longo da década de 90 é outra conclusão de destaque. Por certo, a abertura comercial e a restrição de recursos de financiamento estimulou uma alocação mais eficiente dos fatores de produção.

Será útil e importante aprofundar a análise das relações intersetoriais, o que poderia melhorar a capacidade de explicação dos valores e evolução dos fluxos de excedente da agricultura. Setores, por exemplo, como refino de petróleo e fabricação de produtos químicos diversos (adubos e fertilizantes), diretamente ligados à indústria para a agricultura, estão entre os de maior utilização de insumos importados ${ }^{56}$, o que indica forte dependência indireta da agricultura em relação às importações.

\footnotetext{
${ }^{56}$ Ver Furtuoso \& Guilhoto (Op. cit.).
} 
Restam ainda algumas questões a esclarecer. Será que a falta de políticas de incentivos e a queda de investimentos não abreviarão a capacidade do setor agrícola de contribuir de forma expressiva para o crescimento do país? Associe-se a isto a questão sempre complexa da diversidade regional.

O comportamento do consumo, do investimento e do progresso técnico são fatores determinantes do excedente da agricultura nas suas diferentes versões. Por seu turno, esses fatores dependem da organização da agricultura, principalmente no que se refere aos sistemas de produção e de pesquisa, do desenvolvimento de outros setores, de políticas fiscais e de comércio. Isto apenas para citar algumas instituições relevantes. Pesquisas futuras nessa direção poderão esclarecer estas relações e como elas afetam o valor do excedente da agricultura brasileira.

Poderia também ser oportuno comparar os resultados desta pesquisa com os de versões diferenciadas de excedente que incluíssem os impostos pagos pela agricultura, bem como os subsídios e transferências por ela recebidos. 


\begin{abstract}
ANEXOS:
Tabelas contendo os valores em $\mathrm{R} \$$ de 1998 dos resultados apresentados no Capítulo 5
\end{abstract}




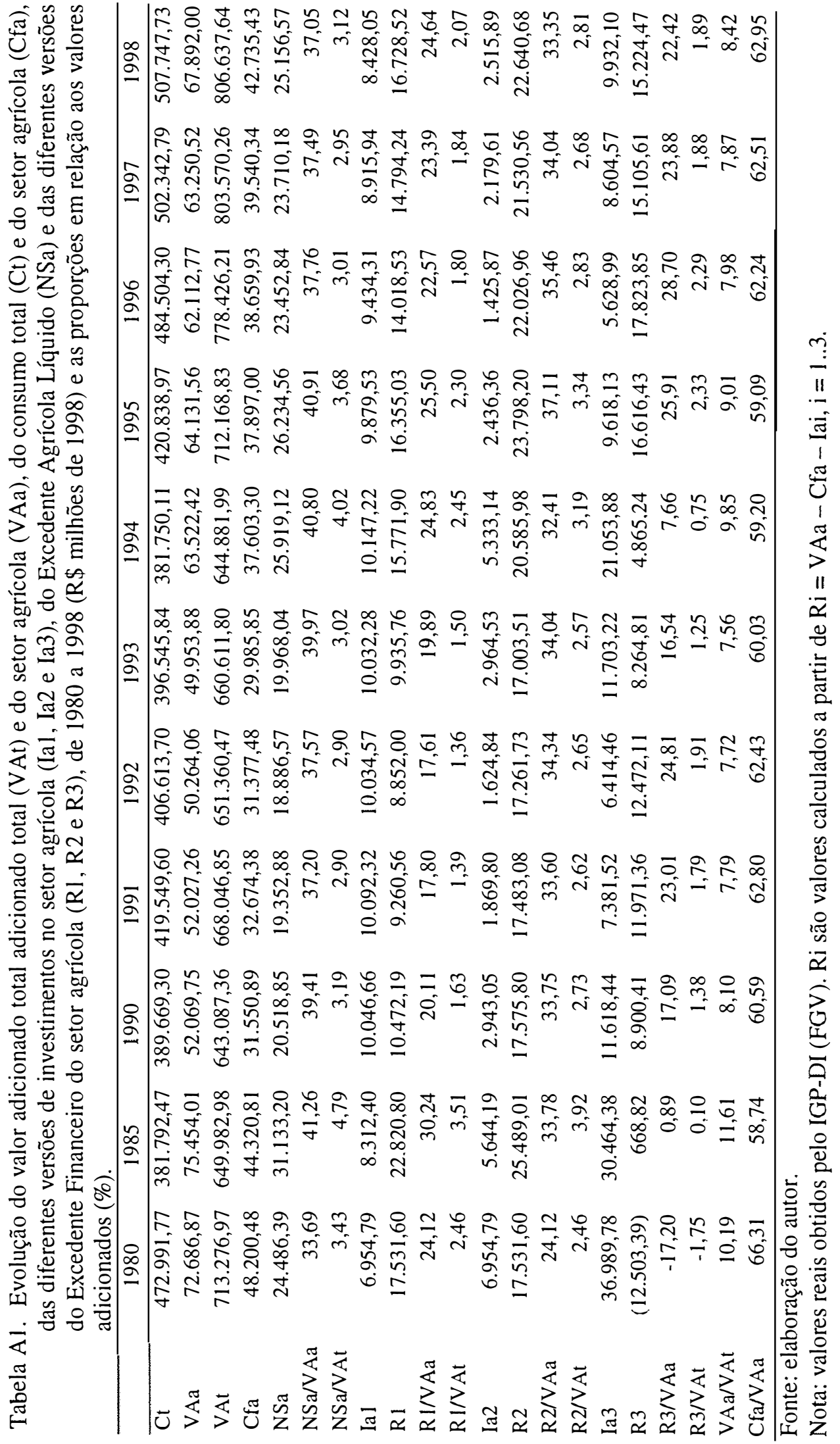


Tabela A2. Evolução do investimento Ia1, Ia2 e Ia3 de 1980 a 1998 (R \$ milhões de 1998).

\begin{tabular}{cccc}
\hline Ano & Ia 1 & Ia2 & Ia3 \\
\hline 1980 & $6.954,79$ & $6.954,79$ & $36.989,78$ \\
1985 & $8.312,40$ & $5.644,19$ & $30.464,38$ \\
1990 & $10.046,66$ & $2.943,05$ & $11.618,44$ \\
1991 & $10.092,32$ & $1.869,80$ & $7.381,52$ \\
1992 & $10.034,57$ & $1.624,84$ & $6.414,46$ \\
1993 & $10.032,28$ & $2.964,53$ & $11.703,22$ \\
1994 & $10.147,22$ & $5.333,14$ & $21.053,88$ \\
1995 & $9.879,53$ & $2.436,36$ & $9.618,13$ \\
1996 & $9.434,31$ & $1.425,87$ & $5.628,99$ \\
1997 & $8.915,94$ & $2.179,61$ & $8.604,57$ \\
1998 & $8.428,05$ & $2.515,89$ & $9.932,10$ \\
\hline
\end{tabular}

Fonte: elaboração do autor.

Tabela A3. Evolução das transferências invisíveis (RI1), visíveis (RV1) e totais (RVI1), de excedente financeiro R1 (R \$ milhões de 1998) e das relações RI1/RVI1, RVI1/R1, RVI1/VAa e RVI1/VAt de 1990 a 1998.

\begin{tabular}{|c|c|c|c|c|c|c|c|c|}
\hline \multirow{2}{*}{ Ano } & RI1 & RV1 & RVI1 & $\mathrm{R} 1$ & RI1/RVI1 & RVI1/R1 & $\mathrm{VI} 1 / \mathrm{VAa}$ & RVI1/VAt \\
\hline & \multicolumn{4}{|c|}{ (R\$ milhões de 1998) } & \multicolumn{4}{|c|}{$(\%)$} \\
\hline 1990 & $17.092,52$ & $11.115,70$ & $28.208,22$ & $10.472,19$ & 60,59 & 269,36 & 54,17 & 4,39 \\
\hline 1991 & $18.039,47$ & $10.090,58$ & $28.130,04$ & $9.260,56$ & 64,13 & 303,76 & 54,07 & 4,21 \\
\hline 1992 & $14.243,68$ & $9.263,20$ & $23.506,88$ & $8.852,00$ & 60,59 & 265,55 & 46,77 & 3,61 \\
\hline 1993 & $6.512,60$ & $9.783,94$ & $16.296,53$ & $9.935,76$ & 39,96 & 164,02 & 32,62 & 2,47 \\
\hline 1994 & 794,84 & $14.775,93$ & $15.570,78$ & $15.771,90$ & 5,10 & 98,72 & 24,51 & 2,41 \\
\hline 1995 & $9.627,66$ & $17.181,28$ & $26.808,94$ & 16.355 .03 & 35,91 & 163,92 & 41,80 & 3,76 \\
\hline 1996 & $10.950,02$ & $14.674,60$ & $25.624,62$ & $14.018,53$ & 42,73 & 182,79 & 41,25 & 3,29 \\
\hline 1997 & $9.957,39$ & 15.286 .78 & $25.244,17$ & $14.794,24$ & 39,44 & 170,64 & 39,91 & 3,14 \\
\hline 1998 & $8.254,84$ & $16.728,52$ & $24.983,36$ & $16.728,52$ & 33,04 & 149,35 & 36,80 & 3,10 \\
\hline
\end{tabular}

Fonte: elaboração do autor. 
Tabela A4. Evolução das transferências invisíveis (RI2), visíveis (RV2), totais (RVI2), do excedente financeiro R2 ( $\mathrm{R} \$$ milhões de 1998) e das relações RI2/RVI2, RVI2/R2, RVI2/VAa e RVI2/VAt de 1990 a 1998.

\begin{tabular}{|c|c|c|c|c|c|c|c|c|}
\hline \multirow{2}{*}{ Ano } & RI2 & RV2 & RVI2 & $\mathrm{R} 2$ & RI2/RVI2 & $\mathrm{RVI2/R2}$ & $\mathrm{II} 2 / \mathrm{V}$ & RVI2/VAt \\
\hline & \multicolumn{4}{|c|}{ (R\$ milhões) } & \multicolumn{4}{|c|}{$(\%)$} \\
\hline 1990 & $14.173,64$ & $18.655,82$ & $32.829,45$ & $17.575,80$ & 43,17 & 186,79 & 63,05 & 5,10 \\
\hline 1991 & $14.571,12$ & $19.050,08$ & $33.621,19$ & $17.483,08$ & 43,34 & 192,31 & 64,62 & 5,03 \\
\hline 1992 & $11.351,15$ & $18.063,59$ & $29.414,74$ & 17.261 .73 & 38,59 & 170,40 & 58,52 & 4,52 \\
\hline 1993 & $5.362,38$ & $16.743,68$ & $22.106,06$ & $17.003,51$ & 24,26 & 130,01 & 44,25 & 3,35 \\
\hline 1994 & 714,71 & $19.286,02$ & $20.000,73$ & $20.585,98$ & 3,57 & 97,16 & 31,49 & 3,10 \\
\hline 1995 & $8.127,76$ & $25.000,48$ & $33.128,24$ & $23.798,20$ & 24,53 & 139,20 & 51,66 & 4,65 \\
\hline 1996 & $9.126,67$ & $23.057,83$ & $32.184,50$ & $22.026,96$ & 28,36 & 146,11 & 51,82 & 4,13 \\
\hline 1997 & $8.573,13$ & $22.247,38$ & $30.820,50$ & $21.530,56$ & 27,82 & 143,15 & 48,73 & 3,84 \\
\hline 1998 & $7.300,96$ & $22.640,68$ & $29.941,64$ & $22.640,68$ & 24,38 & 132,25 & 44,10 & 3,71 \\
\hline
\end{tabular}

Fonte: elaboração do autor.

Tabela A5. Evolução das transferências invisíveis (RI3), visíveis (RV3) e totais (RVI3), do excedente financeiro R3 ( $\mathrm{R} \$$ milhões de 1998) e das relações RI3/RVI3, RVI3/R3, RVI3/VAa e RVI3/VAt de 1990 a 1998.

\begin{tabular}{|c|c|c|c|c|c|c|c|c|}
\hline \multirow{2}{*}{ Ano } & RI3 & RV3 & RVI3 & R3 & RI3/RVI3 & RVI3/R3 & $\mathrm{VI} 3 / \mathrm{VAa}$ & RVI3/VAt \\
\hline & \multicolumn{4}{|c|}{ (R\$ milhões de 1998) } & \multicolumn{4}{|c|}{$(\%)$} \\
\hline 1990 & $17.738,37$ & $9.447,34$ & $27.185,71$ & $8.900,41$ & 65,25 & 305,44 & 52,21 & 4,23 \\
\hline 1991 & $16.896,02$ & $13.044,35$ & $29.940,37$ & $11.971,36$ & 56,43 & 250,10 & 57,55 & 4,48 \\
\hline 1992 & $12.998,54$ & $13.051,48$ & $26.050,02$ & $12.472,11$ & 49,90 & 208,87 & 51,83 & 4,00 \\
\hline 1993 & $6.784,53$ & $8.138,52$ & 14.923 .05 & $8.264,81$ & 45,46 & 180,56 & 29,87 & 2,26 \\
\hline 1994 & 976,39 & $4.558,01$ & 5.534 .41 & $4.865,24$ & 17,64 & 113,75 & 8,71 & 0,86 \\
\hline 1995 & $9.574,99$ & $17.455,89$ & $27.030,88$ & $16.616,43$ & 35,42 & 162,68 & 42,15 & 3,80 \\
\hline 1996 & $10.083,63$ & $18.658,01$ & $28.741,64$ & $17.823,85$ & 35,08 & 161,25 & 46,27 & 3,69 \\
\hline 1997 & $9.893,40$ & $15.608,51$ & $25.501,92$ & $15.105,61$ & 38,79 & 168,82 & 40,32 & 3,17 \\
\hline 1998 & $8.497,51$ & $15.224,47$ & $23.721,98$ & $15.224,47$ & 35,82 & 155,81 & 34,94 & 2,94 \\
\hline
\end{tabular}

Fonte: elaboração do autor. 


\section{REFERÊNCIAS BIBLIOGRÁFICAS}

ALMEIDA, A. Mercados informais como fonte alternativa de liquidez para os agricultores. Piracicaba, 1994. 196p. Dissertação (Mestrado) - Escola Superior de Agricultura "Luiz de Queiroz", Universidade de São Paulo

ALVES, A.F. Análise de qualidade de vida e grupos sociais organizados em Vera Cruz, Estado de São Paulo. Piracicaba, 1996. 160p. Dissertação (Mestrado) - Escola Superior de Agricultura "Luiz de Queiroz", Universidade de São Paulo

ALVES, A.F.; SHIKIDA, P.F.A.; ARAÚJO, P.F.C. Notas sobre a importância do excedente financeiro na agricultura. Tempo da Ciência, v.3, n.5, p.65-74, jan./jun. 1996.

ALVES, A.F.; PERES, F.C. Desenvolvimento municipal e algumas relações com a região e o rural: o caso de Vera Cruz, SP (compact disc). In: CONGRESSO BRASILEIRO DE ECONOMIA E SOCIOLOGIA RURAL, 37, Foz do Iguaçu, 1999. Anais. Foz do Iguaçu: SOBER, 1999.

ASSOCIAÇÃO NACIONAL PARA DIFUSÃO DE ADUBOS E CORRETIVOS AGRÍCOLAS - ANDA. Anuário estatístico do setor de fertilizantes, vários volumes. 
ASSOCIAÇÃO NACIONAL PARA DIFUSÃO DE ADUBOS E CORRETIVOS AGRÍCOLAS - ANDA. Consumo de fertilizantes 1998. http://www.anda.org.br. (13/01/2000).

ANDRADE, S.C.; NAJBERG, S. Uma matriz de contabilidade social atualizada para o Brasil. In: ENCONTRO NACIONAL DE ECONOMIA, 25., Recife, 1997. Anais. Recife: ANPEC, 1997. v.3. p.1846-59.

ASSOCIAÇÃO NACIONAL DE FABRICANTES DE VEÍCULOS AUTOMOTORES

- ANFAVEA. Anuário estatístico da indústria automobilística brasileira - 1999. www.anfavea.com.br. $(22 / 11 / 1999)$

ARAÚJO, P.F.C.; SCHUH, G.E. Desenvolvimento econômico e o papel da agricultura. In: Economia e administração agroindustrial. Piracicaba: DESR/ESALQ/USP, 1995. p.1-28. (Série Didática, 96)

BACHA, E. Industrialization and agricultural development. In: MEIER, G.M. Leading issues in economic development. 6.ed. New York: Oxford University Press, 1995. p.385-9.

BAER, W. A economia brasileira. São Paulo: Nobel, 1996. 416p.

BAER, W. Industrialização e desenvolvimento econômico no Brasil. 7.ed. Rio de Janeiro: Fundação Getúlio Vargas, 1965. 593p.

BARROS, A.L.M. de. Capital, produtividade e crescimento da agricultura: o Brasil de 1970 a 1995. Piracicaba, 1999. 149p. Tese (Doutorado) - Escola Superior de Agricultura "Luiz de Queiroz", Universidade de São Paulo

BONELLI, R.; FONSECA, R. Ganhos de produtividade e de eficiência: novos resultados para a economia brasileira. Rio de Janeiro: IPEA, 1998. p.16-21. (Texto para Discussão, n.557). 
BRANDÃO, A.S.P.; ALVES, E. Elementos de uma estratégia para o desenvolvimento da agricultura brasileira. Rio de Janeiro: EPGE, 1993. 30p. (Ensaios Econômicos, 209, versão preliminar)

BRASIL: índices de preços recebidos e pagos pelos agricultores. Agroanalysis, v.19, n.10, p.60, out. 1999.

CHENERY, H. Introduction to Part 2. In: CHENERY, H.; SRINIVASAN, T.N. Handbook of development economics. Amsterdan: Elsevier Science Publishers, 1988. v.1, p.197-202.

COLOMÉ, R. Excedente financiero del sector agropecuario argentino. Reflexiones en torno de un trabajo anterior y nueva estimación. Desarrollo Económico, v.18, n.70, p.275-82, Jul./Sep. 1978.

DELGADO, G.L. Padrões de desenvolvimento da agricultura brasileira no Pós-Guerra (1947-1988). In: CONGRESSO BRASILEIRO DE ECONOMIA E SOCIOLOGIA RURAL, 27., Piracicaba, 1989. Anais. Piracicaba: SOBER, 1989. p.124-9.

EICHER, C.; WITT, L. (Ed.) Agriculture in economic development. New York: McGraw-Hill, 1964. 415p.

EVANGELISTA, F.R. O excedente financeiro do setor agrícola nordestino. Piracicaba, 1997. 136p. Dissertação (Mestrado) - Escola Superior de Agricultura "Luiz de Queiroz", Universidade de São Paulo

FOOD AND AGRICULTURE ORGANIZATION OF THE UNITED NATIONS FAO. Production Yearbook - 1997. Rome: FAO, 1998. v.51. p. viii. (FAO Statistical Series, n.142)

FOOD AND AGRICULTURE ORGANIZATION OF THE UNITED NATIONS FAO. Explanatory notes. http://www.fao.org/waicent/faostat/agricult/annual1e.htm. (14/12/1999) 
FEI, J.C.H.; RANIS, G. Agrarianismo, dualismo e desenvolvimento econômico. In: ARAÚJO, P.F.C; SCHUH, G.E. (Coord.) Desenvolvimento da agricultura: natureza do processo e modelos dualistas. São Paulo: Pioneira, 1975. p.101-36. (Biblioteca Pioneira de ciências sociais. Economia)

FERREIRA FILHO, J.B.S. Notas a respeito do desempenho da agricultura brasileira no período 1980-1991. Revista de Economia e Sociologia Rural, v.32, n.3, p.225-35, jul./set. 1994

FERREIRA FILHO, J.B.S. Ajustamento estrutural e crescimento da agricultura na década de oitenta: notas adicionais. Revista de Economia Política, v.18, n. 4, p. 84-95, out./dez. 1998.

FERREIRA FILHO, J.B.S; COSTA, A.C.F.A. O crescimento da agricultura e o consumo de máquinas agrícolas no Brasil. (compact disc). In: CONGRESSO BRASILEIRO DE ECONOMIA E SOCIOLOGIA RURAL, 37., Foz do Iguaçu, 1999. Anais. Foz do Iguaçu: SOBER, 1999.

FURTADO, C. Formação econômica do Brasil. 24.ed. São Paulo: Nacional, 1991. 248p. (Biblioteca universitária. Série 2. Ciências sociais, v.23)

GASQUES, J.G.; VILLA VERDE, C.M. Gastos públicos na agricultura: algumas questões. In: CONGRESSO BRASILEIRO DE ECONOMIA E SOCIOLOGIA RURAL, 29., Campinas, 1991. Anais. Campinas: SOBER, 1991. p.236-53.

$\mathrm{GO}, \mathrm{N}$. Intersectoral resource transfer and rural credit in Brazil: regions and classes. TTexto preparado para o Rural Development Strategies workshop of May 56, 1997, World Bank, Washington, D. C./

GOLDIN, I.; REZENDE, G.C. A agricultura brasileira na década de 80: crescimento numa economia em crise. Rio de Janeiro: IPEA, 1993. 119p. (Série IPEA, 138)

GONZALEZ, B.C.R.; COSTA, S.M.A.L. Agricultura brasileira: modernização e desempenho. Teoria e Evidência Econômica, v.5, n.10, p.7-35, maio 1998. 
GRILICHES, Z. Measuring inputs in agriculture: a critical survey. Journal of Farm Economics, v.42, n.5, p.1411-27, Dec. 1960.

GUILHOTO, J. J. M.; SONIS, M.; HEWINGS, G. J. D.; MARTINS, E. B. Índices de ligações e setores-chave na economia brasileira: 1959/80. Pesquisa e Planejamento Econômico, v.24, n.2, p.287-314, ago. 1994.

GUTIERREZ, R.R.; BARBERO, A.C. Estimación del excedente financiero agropecuario, 1970-1985. Revista Argentina de Economía Agraria, v.2, p.13750, 1988.

ÍNDICES econômicos. Conjuntura Econômica, vários números.

INSTITUTO BRASILEIRO DE GEOGRAFIA E ESTATÍsticA. Censo Agropecuário 1980 - Brasil. Rio de Janeiro: IBGE, 1984. n.1. p.50. (Recenseamento geral do Brasil 1980, 9: v.2, t. 3)

INSTITUTO BRASILEIRO DE GEOGRAFIA E ESTATÍSTICA. Brasil. Novo Sistema de Contas Nacionais. Medotologia e resultados provisórios ano-base 1980. Anexo I: Tabelas. Rio de Janeiro: IBGE, 1988. v.1 (Texto para discussão, n. 10)

INSTITUTO BRASILEIRO DE GEOGRAFIA E ESTATÍSTICA. Matriz de insumo produto: Brasil - 1980. Rio de Janeiro: IBGE, 1989. 204p. (Série Relatórios Metodológicos, v.7)

INSTITUTO BRASILEIRO DE GEOGRAFIA E ESTATÍsticA. Censo Agropecuário 1985 - Brasil. Rio de Janeiro: IBGE, n.1, 1991. p.52.

INSTITUTO BRASILEIRO DE GEOGRAFIA E ESTATÍSTICA. Matriz de InsumoProduto Brasil. Metodologia. Resultados de 1990-1995 (compact disc). Rio de Janeiro: IBGE, 1997a 
INSTITUTO BRASILEIRO DE GEOGRAFIA E ESTATÍSTICA. Sistema de Contas Nacionais - Brasil: 1990-1996 (compact disc). Rio de Janeiro: IBGE, 1997b.

INSTITUTO BRASILEIRO DE GEOGRAFIA E ESTATÍSTICA. Sistema de Contas Nacionais: Tabelas de Recursos e Usos: metodologia. Rio de Janeiro: IBGE, 1997c. 49p. (Textos para Discussão, n.88)

INSTITUTO BRASILEIRO DE GEOGRAFIA E ESTATÍstica. Censo Agropecuário 1995/1996 - Brasil. Rio de Janeiro: IBGE, n.1, 1998a. p.94.

INSTITUTO BRASILEIRO DE GEOGRAFIA E ESTATÍsTICA. Sistema de Contas Nacionais - Brasil : resultados preliminares 1997. Rio de Janeiro: IBGE, $1998 \mathrm{~b}$.

INSTITUTO BRASILEIRO DE GEOGRAFIA E ESTATÍSTICA. Contas Regionais do Brasil 1985-1997: informações por unidade da federação (compact disc). Rio de Janeiro: IBGE, 1999a.

INSTITUTO BRASILEIRO DE GEOGRAFIA E ESTATÍSTICA. Matriz de insumo produto: Brasil - 1985. $\mathrm{ftp} / / / \mathrm{ftp} . i b g e . o r g / \mathrm{d} \% 3 \mathrm{~A} / \mathrm{ftp} /$ Contas nacionais/ Matriz de Insumo Produto/1985/ (25/11/1999b).

INSTITUTO BRASILEIRO DE GEOGRAFIA E ESTATÍSTICA. Matriz de insumo produto: Brasil - 1996. $\quad$ ftp://ftp.ibge.org/d\%3A/ftp/Contas nacionais/ Matriz de Insumo Produto/1996/ (25/11/1999c).

INSTITUTO BRASILEIRO DE GeOgRAfia E estatística. Pesquisa de Orçamentos Familiares. $\quad$ ftp://ftp.ibge.org/ftp/Orcamento Familiar/ Pesquisa de Orcamentos Familiares 1995 96. (22/11/1999d).

INSTITUTO BRASILEIRO DE GEOGRAFIA E ESTATÍSTICA. Sistema de Contas Nacionais - Brasil: resultados preliminares 1998. Rio de Janeiro: IBGE, 1999e.

INSTITUTO BRASILEIRO DE GEOGRAFIA E ESTATÍSTICA. Contagem da população: 1996. http://www.ibge.gov.br/estatisticas/populacao/contagem/ caracteristicas/Brtabl.shtm (10/01/2000). 
ISHIKAWA, S. Economic development in Asian perspective. Tokyo: Kinokuniya Bookstore, 1967a. 468p. (Economic Reseach Series, 8).

ISHIKAWA, S. Resource flow between agriculture and industry: the Chinese experience. Developing Economies, v.5, n.1, p.3-49, Mar. 1967 b.

JOHNSTON, B.F.; KILBY, P. Agricultura e transformação estrutural: estratégias econômicas de países em desenvolvimento. Rio de Janeiro: Zahar, 1977. 468p.

JOHNSTON, B.F.; MELLOR, J.W. The role of agriculture in economic development. American Economic Review, v.51, n.4, p.566-93, Sep. 1961.

KARSHENAS, M. Oil income, industrialization bias, and the agricultural squeeze hypothesis: new evidence on the experience of Iran. The Journal of Peasant Studies, v.17, n.2, p.245-72, Jan. 1990.

KARSHENAS, M. Concepts and measurement of agricultural surplus: a new accounting framework with application to Iran. The Journal of Peasant Studies, v.21, n.2, p.235-61, Jan. 1994.

KARSHENAS, M. Capital accumulation and agricultural surplus in Sub-Saharian Africa and Asia. Geneva: UNCTAD, 1998. 77p. (African development in a comparative perspective, Study n.1)

KUZNETS, S. Economic growth and the contribution of agriculture: notes on measurement. In: EICHER, C.; WITT, L. (Ed.) Agriculture in economic development. New York: McGraw-Hill, 1964. Chapter 5, p.102-19.

LEWIS, A.W. Complementarity of industry and agriculture. In: MEIER, G.M. Leading issues in economic development. 6.ed. New York: Oxford University Press, 1995a. p.390-1. 
LEWIS, A.W. Overcoming the weakeness of agriculture. In: MEIER, G.M. Leading issues in economic development. 6.ed. New York: Oxford University Press, 1995b. p.391-4.

LIEBHARDT, M.E. Ajustamento do setor agrícola às mudanças no crédito rural. Brasília: CFP, 1988. 109p. (Coleção Análise e Pesquisa, v.35)

LITTLE, I.M.D. Economic development: theory, policy, and international relations. New York: Basic Books, 1982. 452 p.

MARTIN, M.A. Modernization of Brazilian agriculture: an analysis of unbalanced development. Purdue, 1976. 500p. Thesis $(\mathrm{PhD})$ - Purdue University

MEIER, G.M. Leading issues in economic development. 6.ed. New York: Oxford University Press, 1995. Chapter 8, p.395-452.

MELLOR, J.W. Agricultural development and the intersectoral transfer of resources. In: EICHER, C.K.; STAATZ, J.M. (Ed.) Agricultural development in the Third World. Baltimore: The Johns Hopkins University Press, 1985. Chapter 9, p.13646.

MELO, F.H. de. Tendência de queda nos preços reais dos insumos agrícolas. Revista de Economia Política, v.12, n.l, p.141-6, jan./mar. 1992

MILLAR, J.R. Soviet rapid development and the agricultural surplus hypothesis. Soviet Studies, v.22, p.77-91, 1970.

MORRISON, C; THORBECKE, E. The concept of the agricultural surplus. World Development, v.18, n.8, p.1081-95, Aug. 1990.

MUNDLE, S. Inter-sectoral resource flows in Post-Colonial India. Indian Economic Review, v.12, n.2, p.151-67, 1977. 
MUNDLE, S.; OHKAWA, K. Agricultural surplus flow in Japan, 1888-1937. The Developing Economies, v.12, n.3, p.247-65, Sep. 1979.

NICHOLLS, W.H. The place of agriculture in economic development. In: EICHER, C.; WITT, L. (Ed.) Agriculture in economic development. New York: McGrawHill, 1964. Chapter 1, p.11-44.

NICHOLLS, W.H. A economia agrícola brasileira: desempenho e política recente. In: CONTADOR, C.R. (Ed.) Tecnologia e desenvolvimento agrícola. Rio de Janeiro: IPEA/INPES, 1975. p.46-87. (Série Monográfica, 17)

NICHOLLS, W.H. O "excedente agrícola" como fator de desenvolvimento econômico. In: ARAÚJO, P.F.C; SCHUH, G.E. (Coord.). Desenvolvimento da agricultura: natureza do processo e modelos dualistas. São Paulo: Pioneira, 1975. p.3-38. (Biblioteca Pioneira de ciências sociais. Economia)

OHKAWA, K.; ROSOVSKY, H. The role of agriculture in modern Japanese economic development. Economic Development and Cultural Change, v.9, part I, p.43-67, 1961.

OLIVEIRA, J.C. Transferências de recursos da agricultura no Brasil: 1950/74. Pesquisa e Planejamento Econômico, v.14, n.3, p.773-821, dez. 1984.

OWEN, W.F. A dupla pressão do processo de desenvolvimento sobre a agricultura. In: ARAÚJO, P.F.C; SCHUH, G.E. (Coord.) Desenvolvimento da agricultura: natureza do processo e modelos dualistas. São Paulo: Pioneira, 1975. p.39-65. (Biblioteca Pioneira de ciências sociais. Economia)

PINHEIRO, A.C. Retrospectiva e perspectivas para a economia brasileira: uma análise setorial. Rio de Janeiro: BNDES, 1995. 38p. (Textos para Discussão, 28).

PRODUÇÃO da lavoura. Boletim do Banco Central, vários números. 
REZENDE, G.C. Política econômica e agricultura na década de 80. In: CONGRESSO BRASILEIRO DE ECONOMIA E SOCIOLOGIA RURAL, 27., Piracicaba, 1989. Anais. Piracicaba: SOBER, 1989. p.284-309

REZENDE, G.C. Do Cruzado ao Collor: os planos de estabilização e a agricultura. Revista de Economia Política, v.12, n.2, p.106-25, abr./jun. 1992

RODRIGUES, R.L.; GUILHOTO, J.J.M. Uma análise dos impactos da abertura comercial sobre a estrutura produtiva da economia brasileira: 1990 a 1995. In: MONTOYA, M.A. (Org.) Relações setoriais do MERCOSUL e da economia brasileira: uma abordagem de equilíbrio geral do tipo insumo-produto. Passo Fundo: EDIUPF, 1998. p.131-50.

SCHUH, G.E. Effects of some general economic development policies on agricultural development. American Journal of Agricultural Economics, v.50, n.5, p.128393, Dec. 1968.

SCHUH, G.E. Pesquisa sobre o desenvolvimento agrícola no Brasil. São Paulo: Atlas, 1971. 228p.

SCHUH, G.E. A modernização da agricultura brasileira: uma interpretação. In: CONTADOR, C.R. (Ed.) Tecnologia e desenvolvimento agrícola. Rio de Janeiro: IPEA/NPES, 1975. p.7-45. (Série Monográfica, 17)

SCHUH, G.E. Política agrícola numa economia internacional bem integrada: o caso do Brasil. Revista de Economia e Sociologia Rural, v.27, n.2, p.107-24, abril/jun. 1989.

SCHUH, G.E. A agricultura no Brasil: política, modernização e desenvolvimento econômico. Revista de Política Agrícola, n.2, p.15-21, abril/maio/jun. 1997.

SILVA, G.L.S.P. Reflexões sobre o papel da agricultura no Brasil. Agricultura em São Paulo, v.29, n.1-2, p.1-20, 1982. 
SILVA, J.G. da. O novo rural brasileiro. http://www.eco.unicamp.br/pesquisa/frame inic.html (07/04/1999). /Publicado em: Nova economia, v.7, n.1, p.43-81, maio $1997 /$.

STAATZ, J.M.; EICHER. C.K. Agricultural development ideas in historical perspective. In: EICHER, C.K.; STAATZ, J.M. (Ed.) Agricultural development in the Third World. Baltimore: The Johns Hopkins University Press, 1985. Chapter 1, p.3-30.

STERN, N. Growth theories, old and new, and the role of agriculture in economic development. London: Suntory-Toyota International Centre for Economic and Related Disciplines/London Scholl of Economics, 1994. 148p.

STEVENS, R.D.; JABARA, C.L. Agricultural development principles: economic theory and empirical evidence. Baltimore: The Johns Hopkins University Press, 1988. 478p.

SYRQUIN, M. Patterns of structural change. In: CHENERY, H.; SRINIVASAN, T.N. Handbook of development economics. Amsterdan: Elsevier Science Publishers, 1988. v.1. Chapter 7, p.203-73.

TEIXEIRA, E.C. Política agrícola e o combate à fome. Conjuntura Econômica, v.48, n.9, p.41-3, set. 1994.

TEUBAL, M. Estimaciones del "excedente financiero" del sector agropecuario argentino. Desarrollo Económico, Revista de Ciencias Sociales, v.14, n.56, p.677-97, Ene./Mar. 1975.

TEUBAL, M. Generation and transfer of an agricultural surplus in Argentina. West Lafayette: Purdue University, 1971. 58p. 
THORBECKE, E. Structural adjustment and its impact on employment, poverty and rural development: methodological questions and issues. Cornell University, 1987. $22 \mathrm{p}$.

TIMMER, C.P. The agricultural transformation. In: CHENERY, H.; SRINIVASAN, T.N. (Ed.) Handbook of Economic Development. Amsterdam: Elsevier Science Publishers, 1988, v.1 Chapter 8, p.275-331.

TWEETEN, L. Farm policy analysis. Boulder: Westview Press, 1989. 399p.

VEIGA, A. Efeitos da política comercial brasileira no setor agrícola. In: ARAÚJO, P.F.C; SCHUH, G.E. (Coord.) Desenvolvimento da agricultura: análise de política econômica. São Paulo: Pioneira, 1975. p.15-32. (Biblioteca Pioneira de ciências sociais. Economia)

YOTOPOULOS, P.A.; NUGENT, J.B. Economics of development: empirical investigations. New York: Harper \& Row Publishers, 1976. 478p. 